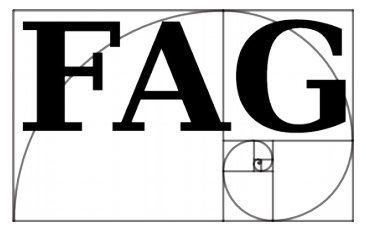

Filozoficzne Aspekty Genezy - 2018, t. 15

Philosophical Aspects of Origin

s. $71-137$

ISSN 2299-0356

http://www.nauka-a-religia.uz.zgora.pl/images/FAG/2018.t.15/art.06.pdf

Krzysztof J. Kilian

\title{
Argumenty przeciwko naturalizmowi jako epistemicznemu układowi odniesienia
}

\section{Uwagi wstępne}

Naturalizm metodologiczny jest jedynym powszechnie znanym i dobrze opisanym w filozofii epistemicznym układem odniesienia nauki. ${ }^{1}$ Tworzą go trzy, wywodzące się od Karola Darwina, decyzje. Pierwsza z nich to nakaz przyjmowania jedynie naturalistycznych wyjaśnień dla faktów, procesów i zjawisk. ${ }^{2}$ Decyzja ta uzupełniona została przez angielskiego przyrodnika dwoma

Dr hab. KrZYsztof J. KiLIan, prof. UZ - Uniwersytet Zielonogórski, e-mail: kiliankrzysztof @yahoo.pl.

(C) Copyright by Krzysztof J. Kilian \& Filozoficzne Aspekty Genezy.

${ }^{1}$ Epistemiczne układy odniesienia (EUO) nauki są to przyjmowane na mocy decyzji uczonych niewielkie (dwu- lub trzyelementowe) zbiory najogólniejszych, historycznie zmiennych założeń. Te ostatnie określają konieczne warunki uprawiania nauki. EUO, inaczej to wyrażając, są to najbardziej elementarne założenia dotyczące tego, jak należy uprawiać naukę i jak tego robić nie należy. Wskazują one, co według danej grupy uczonych jest w praktyce naukowej zakazane, a co nie. Wyznaczają tym samym zakres dopuszczalnych rozwiązań problemów.

Przegląd problematyki dotyczącej epistemicznych układów odniesienia przedstawiłem w serii artykułów: „Geneza idei epistemicznych układów odniesienia i ich odmiany”, Filozoficzne Aspekty Genezy 2017, t. 14, s. 137-190, https://tiny.pl/gzx34 (23.11.2018); „Czym są epistemiczne układy odniesienia?”, Filozoficzne Aspekty Genezy 2017, t. 14, s. 191-236, https://tiny.pl/g8xqp (23.11.2018); „Epistemiczne układy odniesienia a problem interteoretycznej niewspółmierności — część 1", Filozoficzne Aspekty Genezy 2017, t. 14, s. 237-280, https://tiny.pl/gzx3s (08.10. 2018); „Epistemiczne układy odniesienia a problem interteoretycznej niewspółmierności — część 2", Filozoficzne Aspekty Genezy 2017, t. 14, s. 281-325, https://tiny.pl/gzx3v (23.11.2018).

${ }^{2}$ Por. Karol DARWIN, O powstawaniu gatunków drogą doboru naturalnego, czyli o utrzymaniu się doskonalszych ras w walce o byt. Dzieła wybrane, t. 2, przeł. Szymon Dickstein i Józef Nusbaum, Państwowe Wydawnictwo Rolnicze i Leśne, Warszawa 1959, s. 386. 
innymi decyzjami, wykluczającymi wyjaśnienia antynaturalistyczne. Są to zakazy przyjmowania wyjaśnień powołujących się na przyczyny nadnaturalne ${ }^{3} \mathrm{i}$ celowe. ${ }^{4}$

W takiej postaci naturalizm metodologiczny jest jednocześnie nakazem ograniczania badań wyłącznie do świata przyrody i nakazem przyjmowania jedynie naturalistycznych wyjaśnień dla faktów i procesów, wraz z jednoczesnym zakazem przyjmowania wyjaśnień antynaturalistycznych. Ten ostatni zakaz, co należy podkreślić, dotyczy dwóch różnych typów wyjaśnień: $\mathrm{z}$ jednej strony powołujących się na przyczyny nadnaturalne (antynaturalizm ${ }_{1}$ ), zaś z drugiej — na inteligentne (antynaturalizm ${ }_{2}$ ).

W myśl tego podejścia współcześnie funkcjonują cztery epistemiczne układy odniesienia, które układają się w następujące pary:

naturalizm antynadnaturalistyczny — nadnaturalizm (antynaturalizm 1 );

naturalizm antyartyficjalistyczny — artyficjalizm (antynaturalizm 2$).{ }^{5}$

\footnotetext{
${ }^{3}$ Por. Darwin, O powstawaniu gatunków..., s. 386.
}

${ }^{4}$ Por. Karol Darwin, Autobiografia i wybór listów. Dziela wybrane, t. 8, przeł. A. Iwanowska, A. Krasicka, J. Połtowicz i S. Skowron, Państwowe Wydawnictwo Rolnicze i Leśne, Warszawa 1960, s. 44. Por. też Grzegorz Malec, „Teologiczne dylematy Karola Darwina”, Roczniki Filozoficzne 2012, t. 60, nr 1, s. 69-70 [67-85], http://tiny.pl/g4751 (23.11.2018).

${ }^{5}$ Por. Kazimierz Jodкоwsкi, „Antynaturalizm teorii inteligentnego projektu”, Roczniki Filozoficzne 2006, t. 54, nr 2, s. $72-73$ [63-76], http://tiny.pl/qzq86 (23.11.2018); Kilıan, „Geneza idei...", s. 139.

Mówiąc o nadnaturalizmie czy artyficjalizmie, na ogół nie ma się na myśli przekonania, zgodnie z którym wyjaśnienia naukowe mogą odwoływać się do bóstw czy innych niż ludzkie inteligencji celowo ingerujących w świat przyrody (por. np. Ronald H. PINE, „But Some of Them Are Scientists, Aren't They?", Creation/Evolution 1984, no. 14, s. 10 [6-18], https://tiny.pl/g2vxk [15.01.2019]; Krzysztof J. Kilian, „Argumenty na rzecz naturalizmu jako epistemicznego układu odniesienia", Filozoficzne Aspekty Genezy 2018, t. 15, s. 19-20 [7-69], https://tiny.pl/txgnc [15. $01.2019]$ ). Innymi słowy, nie twierdzi się, że przesłankami w wyjaśnieniach naukowych są twierdzenia odwołujące się do bóstw lub innych niż ludzkie inteligencji (por. np. Stephen C. MeYer, Signature in the Cell: DNA and the Evidence for Intelligent Design, Harper One, New York 2009, s. 171; Małgorzata GAZDA, „Stephena C. Meyera koncepcja «podpisu w komórce» a filozoficzne podstawy nauki”, Filozoficzne Aspekty Genezy 2016, t. 13, s. 17 [7-23], https://tiny.pl/g16 kj (15.01.2019); Małgorzata GAZDA, „Zasada naturalizmu metodologicznego czy adekwatności przyczynowej?”, Idź Pod Prad 2015, nr 10-11 (135-136), s. 8-9 [8-9], https://tiny.pl/tqdbj (15.01. 2019); Dariusz SAGan, „Wyjaśnianie za pomocą praw przyrody jako warunek naukowości w sporze o ewolucję i inteligentny projekt”, Studia Philosophiae Christianae 2013, t. 49, nr 1, s. 96-105 
Współcześnie osią sporu o charakter dopuszczalnych wyjaśnień naukowych są nauki o życiu. Dlatego to naturalistyczne kryterium sformułowano przede wszystkim dla tych nauk. ${ }^{6}$ Powszechna akceptacja takiego szerokiego kryterium, rozszerzającego wymogi naturalizmu metodologicznego o decyzję zakazującą dopuszczania wyjaśnień artyficjalistycznych, doprowadziła do poważnych problemów natury teoretycznej. Zaproponowano zespół decyzji niezgodnych z tym, co na co dzień robi się w nauce. Prowadzą one do uznania za nienaukowe tych dyscyplin, którym nikt nie odmawia statusu naukowości. Istnieją

[93-116], https://tiny.pl/q336g (15.01.2019); Dariusz SAGAN, „Spór o możliwość wykrywania projektu w naukach przyrodniczych", Scientia et Fides 2015, vol. 3, nr 1, s. 93-94 [87-113], https://ti ny.pl/gz16f (15.01.2019).

Wedle nadnaturalistycznego EUO w wyjaśnianiu zjawisk przyrodniczych obok przyczyn naturalnych dopuszczać należy przyczyny nadnaturalne - interwencję bytu nadprzyrodzonego, czyli Boga. Zaś artyficjalistyczny EUO przedstawić można jako nakaz dopuszczania w badaniach naukowych obok przyczyn naturalnych również przyczyn sztucznych, inteligentnych (por. KILIAN, „Geneza idei...”, s. 161-167). Argumenty za i przeciw artyficjalizmowi obszernie omawia Dariusz SAGAN, „Teoria inteligentnego projektu - argumenty za i przeciw”, w: Stanisław JANECZEK, Anna Starościc, Dariusz DąbeK i Justyna Herda (red.), Filozofia przyrody, Dydaktyka Filozofii, t. III, Wydawnictwo Katolickiego Uniwersytetu Lubelskiego, Lublin 2013, s. 339-371 [335-383], https://tiny.pl/q336w (23.11.2018).

Ani nadnaturaliści, ani artyficjaliści nie postuluja też badania sfery nadprzyrodzonej (por. np. Kazimierz JoDKowsKI, „Rozpoznawanie genezy: istota sporu ewolucjonizm-kreacjonizm”, Roczniki Filozoficzne 2002, t. 50, z. 3, s. 189 [187-198], https://tiny.pl/xh2bp [15.01.2019]; Dariusz SAGAN, „Naturalizm metodologiczny a zagadnienie prawdy w nauce”, w: Andrzej L. Z $\mathrm{Z}_{\mathrm{A}}$ Chariasz (red.), Poznanie a prawda, Wydawnictwo Uniwersytetu Rzeszowskiego, Rzeszów 2009, s. 169 [167-173], https://tiny.pl/q33sv [15.01.2019]). Artyficjaliści poszukują w świecie śladów aktywności Inteligentnego Projektanta, zaś młodoziemscy kreacjoniści, gdy na przykład chcą uzasadnić biblijną tezę o młodym wieku Ziemi, prowadzą badania nad zmiennym tempem poruszania się ziemskich płyt tektonicznych. Przykładem tych ostatnich badań są prace kreacjonisty, geofizyka i eksperta w projektowaniu komputerowych modeli konwekcji geofizycznej z Los Alamos National Labolatory, Johna R. Baumgardnera. Utrzymuje on pogląd, że pokrywające ziemię płyty geologiczne mogły się kiedyś poruszać tysiące razy szybciej niż obecnie. Jeśli tak było, to w stosunkowo niewielkim okresie czasu mogły zajść duże zmiany geologiczne, co uzasadniałoby część młodoziemskich poglądów kreacjonistycznych (por. np. Kazimierz JoDKowsKI, Metodologiczne aspekty kontrowersji ewolucjonizm-kreacjonizm, Realizm. Racjonalność. Relatywizm, t. 35, Wydawnictwo UMCS, Lublin 1998, s. 242-243; Sharon Begley, „Heretics in the Laboratory”, Newsweek 15 September 1996, s. 82, https://tiny.pl/txgnw (15.01.2019).

Znikoma (a nie zerowa, jak utrzymują niektórzy: por. np. John RENNIE, „15 odpowiedzi na nonsensowne tezy kreacjonistów”, przeł. Karol Sabath, Świat Nauki 2002, nr 9, s. 68 [66-72], https://tiny.pl/gzpws (15.01.2019); Marshall Berman, „Intelligent Design Creationism: A Threat to Society - Not Just Biology", The American Biology Teacher 2003, vol. 65, no. 9, s. 648 [646648], https://tiny.pl/g26n5 [15.01.2019]) obecność wyjaśnień antynaturalistycznych w literaturze 
bowiem dyscypliny (na przykład archeologia) i przedsięwzięcia naukowe (na przykład program SETI), które dopuszczają wyjaśnienia artyficjalistyczne (archeologowie niejednokrotnie stwierdzają, że odkryte przez nich przedmioty są wytworami istot inteligentnych, zaś w ramach SETI poszukiwane są ślady pozaziemskiej inteligencji), a nikt im nie odmawia pretensji do naukowości. Nie jest to oczywiście jedyny powód, dla którego podważa się zasadność naturalizmu metodologicznego.

Cechą wspólną przedstawionych niżej tez i argumentów przeciwko naturalizmowi metodologicznemu jest to, że uznaje się, iż naturalizm ten, gdy traktowany jest jako bezwzględna dyrektywa, jest podejściem destrukcyjnym. Przejawia się to w tym, że naturalizm: źle wpływa na rozwój wiedzy; utrudnia współzawodnictwo; jest tylko częścią określonej tradycji, która została zabsolutyzowana; jest wyłącznie prowizoryczną zasadą; jest arbitralną i szkodliwą regułą; jest podejściem irracjonalnym; jest złą filozofią; jest ujęciem przyjmowanym bezkrytycznie. ${ }^{7}$ Powyższe tezy, wraz z argumentami na ich rzecz, przebadane zostaną w kolejnych częściach.

Na koniec tych rozważań, w podsumowaniu, przedstawiona zostanie pewna dygresja związana z podejmowanym $\mathrm{w}$ tym tekście problemem.

\section{Naturalizm obecnie źle wpływa na rozwój wiedzy}

Twierdzi się, że naturalizm metodologiczny, który

w przeszłości $[\ldots]$ był nam potrzebny, aby nauczyć nas, że nie należy polegać na mi-

naukowej jest, jak zauważono, efektem tego, że podejścia te odrzucane są ,już na gruncie metodologicznym” (por. SAGAN, „Teoria inteligentnego projektu — argumenty...”, s. 369). Por. też Eugenie C. Scott and Henry Cole, „The Elusive Scientific Basis of Creation «Science»”, The Quarterly Review of Biology 1985, vol. 60, s. 25-26 [21-30], https://tiny.pl/tqdzw (15.01.2019); David Buckna, „Do Creationists Publish in Notable Refereed Journals?”, Creation Ministries International April 1997, https://tiny.pl/tqrjs (15.01.2019); JoDKowsKi, Metodologiczne aspekty..., s. 240-247.

${ }^{6}$ Por. np. Francisco J. Ayala, „Darwin's Revolution”, w: John H. CAmpbell and J.W. Schopf (eds.), Creative Evolution!?, Jones and Bartlett, New York 1994, s. 4-5 [1-18].

${ }^{7}$ Zebrane tutaj argumenty pochodzą z różnych tekstów. Niektóre polemizują z naturalizmem metodologicznym, inne go bronią, a jeszcze inne go omawiają. W związku z tym nie zawsze jest tak, że przytaczany autor jest krytykiem zasady naturalizmu metodologicznego. 
stycznych wyjaśnieniach codziennych zjawisk przyrodniczych, ${ }^{8}$

nie powinien być już uznawany za warunek konieczny uprawiania nauki.

2.1. „Naturalizm [...] metodologiczny jest jedną z głównych barier stojących na przeszkodzie owocnego dialogu pomiędzy religią a nauką oraz syntezy poznania pomiędzy tymi dwoma dyscyplinami w ogóle. Dzieje się tak, ponieważ naturalizm zdaje się uniemożliwiać naukową dyskusję nad wieloma istotnymi kwestiami, w tym nad ludzką wolnością, moralnością, celowością w przyrodzie i Bogiem". ${ }^{9}$

Jednak osią tak sformułowanego argumentu jest, będące następstwem ekwiwokacji, nieporozumienie. Wskutek tego argument ten jest wyważaniem otwartych drzwi. Jego autor posługuje się nazwą science wtedy, gdy odnosi ją do współczesnego rozumienia naukowości:

[Nauka (science) to] próba wyjaśnienia świata przyrody za pomocą naturalnych procesów i mechanizmów. ${ }^{10}$

Wyraźnie odnosi tę nazwę również do szerszego, obecnie już, praktycznie rzecz biorąc, nieużywanego w krajach anglojęzycznych, jej rozumienia. Pisze, że naturalizm uniemożliwia naukową (scientific) debatę nad takimi doniosłymi zagadnieniami jak Bóg, ludzka moralność, wolność czy celowość w przyrodzie. Te istotne kwestie to zagadnienia przede wszystkim metafizyki i teologii, czyli dyscyplin, które wspólnie z przyrodoznawstwem, w wiekach średnich, określane były mianem scientia, a dla których w obrębie science nie ma obecnie miejsca. ${ }^{11}$ Nie sugeruje się też w tym argumencie, by powrócić do starszego i zarzuconego już rozumienia naukowości ${ }^{12}$ (którego akceptacja w chwili obecnej

\footnotetext{
${ }^{8}$ Leonard BRAND, „Naturalizm i jego rola w nauce”, przel. Paulina Korzeniewska-Nowakowska, Filozoficzne Aspekty Genezy 2016, t. 13, s. 69 [49-74], https://tiny.pl/g2sg3 (23.11.2018).

${ }^{9}$ Por. Robert A. Delfino, „Replacing Methodological Naturalism”, Metanexus 24 May 2007, https://tiny.pl/thmmz (23.11.2018).

${ }^{10}$ Delfino, „Replacing Methodological Naturalism...”.

${ }^{11}$ Por. np. Ted Peters, „Naturalism of the Gaps”, Theology and Science 2015, vol. 13, no. 1, s. 7 [4-7], https://tiny.pl/g36vq (23.11.2018).

${ }^{12}$ Por. w tej sprawie np. Ernan McMuluin, „Odmiany naturalizmu metodologicznego”, przeł. Ewelina Topolska, Filozoficzne Aspekty Genezy 2012, t. 9, s. 123 [109-129], https://tiny.pl/xh8pf
} 
wcale nie jest przedsięwzięciem prostym ${ }^{13}$ ) i zobaczyć, jakie będą tego efekty.

Odnotować też warto w tym miejscu, że na przeszkodzie owocnego dialogu pomiędzy religią a nauką stoi bariera znacznie większa niż rzekoma niemożność naturalistycznego wyjaśniania zagadnień Boga, moralności, wolności i im podobnych: ${ }^{14}$

Jeśli cudy są integralnym elementem realnych religii i jeśli nauka wyklucza zachodzenie cudów, to konflikt nauka-religia jest w swej najgłębszej istocie nieusuwalny. ${ }^{15}$

2.2. W myśl innego argumentu uczeni powinni podążać za danymi empirycznymi bez względu na to, dokąd ich te dane zaprowadzą, zaś przyjmowanie wyłącznie naturalistycznych wyjaśnień takie poszukiwania uniemożliwia. ${ }^{16}$

\section{(23.11.2018).}

${ }^{13}$ Por. np. William A. Dembsкi, „Powrót projektu do nauk przyrodniczych”, przeł. Dariusz Sagan, Na Poczatku... 2004, nr 9-10 (185-186), s. 326 [323-342], https://tiny.pl/thmgz (23.11. 2018).

${ }^{14}$ Oto jeden z wielu przykładów naturalistycznych wyjaśnień tego typu kwestii, zgodnie z którym tradycyjna religia jest zjawiskiem całkowicie materialnym (por. Edward O. WiLson, O naturze czlowieka, przeł. Barbara Szacka, Wydawnictwo Zysk i S-ka, Poznań 1998, s. 204205):

najbardziej wzniosłe formy praktyk religijnych [...] przynoszą korzyść biologiczną. Dostarczają [...] krzepiącego poczucia tożsamości. [...] religia określa człowieka, dostarcza mu niekwestionowanego uczestnictwa w grupie głoszącej swoją potęgę i w ten sposób daje mu zgodny z jego własnym interesem cel, którym może się w życiu kierować.

WILSON, O naturze czlowieka..., s. 200.

${ }^{15}$ Kazimierz Joркошsкі, „Konflikt nauka-religia a teoria inteligentnego projektu”, w: Kazimierz JоDКоWSкI (red.), Teoria inteligentnego projektu - nowe rozumienie naukowości?, $B i$ blioteka Filozoficznych Aspektów Genezy, t. 2, Wydawnictwo MEGAS, Warszawa 2007, s. 157 [145-180], https://tiny.pl/qzq8f (23.11.2018). Por. też Kazimierz JoDKowsKi, „Dyskordyzm przerywany”, w: Anna Brożek, Alicja Chybińska, Mariusz Grygianiec i Marcin Tkaczyk (red.), Myśli o języku, nauce i wartościach. Seria druga. Profesorowi Jackowi Juliuszowi Jadackiemu w siedemdziesiątą rocznicę urodzin, Wydawnictwo Naukowe Semper, Warszawa 2016, s. 603-604 [592-604].

${ }^{16}$ Por. Michael J. BeHE, „Nieredukowalna złożoność: problem dla ewolucjonizmu darwinowskiego”, przeł. Dariusz Sagan, Filozoficzne Aspekty Genezy 2005/2006, t. 2/3, s. 76-77 [67-96], https://tiny.pl/qzq8n (23.11.2018); SAGan, „Spór o możliwość...”, s. 93-94; Robert A. Delfino, „Zastąpić metodologiczny naturalizm”, s. 10 [1-12], https://tiny.pl/hkjt1 (23.11.2018). 
Problem w tym, że wyrażenie „iść za świadectwami empirycznymi niezależnie od tego, dokąd one prowadzą" ${ }^{17}$ sugeruje akceptację przekonania, zgodnie $\mathrm{z}$ którym istnieją jakieś nieuteoretyzowane obserwacje. Już dawno temu zauważono, że

interpretacja faktów za pomocą teorii przyjętych przez badacza stanowi integralną część doświadczenia [...], w doświadczeniu tym nie jest możliwe rozgraniczenie, oddzielenie stwierdzenia faktów od transformacji, których dokonuje na nich teoria. ${ }^{18}$

Druga część argumentu - przyjmowanie wyłącznie naturalistycznych wyjaśnień utrudnia podążanie za danymi empirycznymi - jest bardziej obiecująca. Występuje ona przeciwko zasadzie względnej autonomii faktów, w myśl której fakty mogące świadczyć na korzyść lub niekorzyść teorii są dostępne bez względu na to, czy znane są alternatywne względem niej rozwiązania. ${ }^{19}$ Jeśli wszystkie obserwacje są uteoretyzowane, to obstawanie przy jednej perspektywie teoretycznej skutecznie utrudnia dostrzeżenie tych faktów, które mogą wyjść na jaw dopiero wtedy, gdy poważnie potraktuje się alternatywne punkty widzenia. ${ }^{20}$

Przykładowo w obrębie gradualistycznego ewolucjonizmu powstały wyjaśnienia (koopcja, narastająca niezbędność, duplikacja genu, łuk rzymski, samo-

Do zagadnienia tego powracam przy okazji analiz innego argumentu (8.3), zgodnie z którym naturalizm jest złą metafizyką.

${ }^{17}$ BeHE, „Nieredukowalna złożoność...”, s. 76.

${ }^{18}$ Pierre Duнem, „Kilka refleksji na temat fizyki eksperymentalnej”, przeł. Monika Sakowska, w: Krzysztof SzlachCic, Filozofia nauki francuskiego konwencjonalizmu, Wydawnictwo Uniwersytetu Wrocławskiego, Wrocław 1994, s. 19 [17-52].

${ }^{19}$ Por. np. Paul K. Feyerabend, „Jak być dobrym empirystą? Wezwanie do tolerancji w kwestiach epistemologicznych", w: Paul K. FEYERABEND, Jak być dobrym empirystą, przeł. Krystyna Zamiara, Państwowe Wydawnictwo Naukowe, Warszawa 1979, s. 39-41 [23-61]; Paul K. FeYerabend, „Linguistic Arguments and Scientific Method”, w: Paul K. Feyerabend, Philosophical Papers. Vol. 1. Realism, Rationalism \& Scientific Method, Cambridge University Press, Cambridge - New York - Portchester - Melbourne - Sydney 1981, s. 157 [146-160]; Paul K. FeYERABEND, Against Method: Outline of an Anarchistic Theory of Knowledge, New Left Books, London 1975, s. 38, 44-46, 179.

${ }^{20}$ Por. np. Paul K. Feyerabend, „Problems of Empiricism”, w: Robert G. Colodny (ed.), Beyond the Edge of Certainty: Essays in Contemporary Science and Philosophy, Prentice-Hall, Englewood Cliffs, New Jersey 1965, s. 150-151 [145-260]. 
organizacja ${ }^{21}$ ), za pomocą których w ewolucyjny sposób thumaczone jest to, co zwolennicy teorii inteligentnego projektu nazwali „nieredukowalną złożonością". ${ }^{22}$ Bez względu na to, kto zwycięży w tej rywalizacji, sukces doprowadzi do wzrostu wiedzy: albo ewolucjoniści uszczegółowią swoje wyjaśnienia i pozbędą się istotnych anomalii, ${ }^{23}$ przez co uodpornią swoje teorie na antynaturalistyczne ataki, albo zwyciężą zwolennicy teorii inteligentnego projektu, czego efektem będzie nowy paradygmat. Zarówno w jednym, jak i w drugim przypadku sformułowane zostaną nowe hipotezy, które prowadzić będą ku innym hipotezom i nowym faktom, co zaowocuje uszczegółowieniem badań nad problemem pochodzenia życia. ${ }^{24}$

\subsection{Zgodnie z podobnym do powyższego (2.2) argumentu,}

nauka bazująca na metodologicznym naturalizmie nie może bezstronnie rozpatrywać świadectw, gdyż nie dopuszcza ona wyjaśnień nienaturalistycznych. ${ }^{25}$

\footnotetext{
${ }^{21}$ Wartość tych wyjaśnień omawia Dariusz SAGAN, „Teoria inteligentnego projektu a naukowa debata nad pochodzeniem", w: Jоркошsкі (red.), Teoria inteligentnego projektu..., s. 97-106 [79-122], https://tiny.pl/qzq8f (16.01.2018).

${ }^{22}$ Wartość tego wyjaśnienia omawia Dariusz SAGAN, „Trzy płaszczyzny argumentu z nieredukowalnej złożoności”, Na Początku ... 2005, nr 5-6 (194-195), s. 177-224 [162-224], https://tiny.pl /xh4f5 (16.01.2019).

${ }^{23}$ Były (obecnie na emeryturze) dyrektor Instytutu Farmacji i Biochemii w Uniwersytecie Johannesa Gutenberga w Moguncji, Klaus Dose, napisał tak:
}

Ponad 30 lat eksperymentowania nad powstaniem życia na polu chemicznej i molekularnej ewolucji doprowadziło raczej do lepszego zrozumienia, jak wielki problem stanowi powstanie życia na Ziemi, niż do rozwiązania tego problemu. Obecnie wszystkie dyskusje na temat głównych teorii $i$ eksperymentów $w$ tej dziedzinie albo kończą się utknięciem w martwym punkcie, albo przyznaniem się do niewiedzy.

Klaus Dose, „The Origin of Life: More Questions Than Answers”, Interdisciplinary Science Reviews 1988, vol. 13, no. 4, s. 348 [348-356] (cyt. za: Michael J. Bene, Czarna skrzynka Darwina. Biochemiczne wyzwanie dla ewolucjonizmu, przeł. Dariusz Sagan, Biblioteka Filozoficznych Aspektów Genezy, t. 4, Wydawnictwo MEGAS, Warszawa 2008, s. 146 [wyróżnienia dodane]).

${ }^{24}$ Por. wypowiedź Krzysztofa Kiliana w: Piotr ByLICA, Kazimierz JodKowski, Krzysztof J. Kilian i Dariusz SaGan, „Dyskusja nad artykułem Adama Groblera, «Słabości eksplanacyjne teorii inteligentnego projektu»", Filozoficzne Aspekty Genezy 2013, t. 10, s. 27-28 [17-63], https:// tiny.pl/tx9ht (16.01.2019).

${ }^{25}$ Por. Erkki V.R. KoJonen, „Methodological Naturalism and the Truth Seeking Objection”, 
Ale niemożliwość bezstronnego rozpatrywania świadectw jest efektem czegoś znacznie bardziej fundamentalnego niż tylko niedopuszczania wyjaśnień antynaturalistycznych. Żadna nauka nie rozpatruje bezstronnie świadectw dlatego, że zawsze przyjmuje jakieś założenia (w tym i wartości), mówiące uczonemu: co istnieje, co należy badać, a jakich badań należy unikać, i jak należy prowadzić badania zgodne $\mathrm{z}$ tymi założeniami:

Decyzje o akceptacji tej oto teorii na podstawie tych oto danych zebranych tą oto metodą itd. mają charakter sądu wartościującego, a nie są rezultatem zastosowania algorytmu wyboru. ${ }^{26}$

Ten stan rzeczy opisany już został jako teza o założeniowości. Zgodnie z nią nauka nie może istnieć bez filozoficznych założeń. ${ }^{27}$ Teza o założeniowości

International Journal for Philosophy of Religion 2016, vol. 79, no. 3, s. 11 [1-26], https://tiny.p1/ thmr7 (23.11.2018).

${ }^{26}$ Agnieszka LeKKa-KowaliK, „Nauka wolna od wartości - groźna utopia współczesnej kultury", https://tiny.pl/thmb7 (23.11.2018).

${ }^{27}$ Por. Kazimierz Jodkowski, „Curriculum Vitae”, https://tiny.pl/gkfxf (23.11.2018).

Teza ta niekiedy uznawana bywa za fałszywą:

Filozoficzne założenia nauki tylko są tak nazywane, a właściwie na taką nazwę nie zasługują. Nie zasługują w tym sensie, że nie są założeniami logicznymi nauki.

Jan WoleŃSKI, „O tak zwanych fillozoficznych założeniach nauki”, w: Stanisław ButRYN (red.), Z zagadnień filozofii nauk przyrodniczych, Polska Akademia Nauk. Instytut Filozofii i Socjologii, Warszawa 1991, s. 16 [7-16].

Autor powyższego wniosku uzasadnił tezę, że pewnego rodzaju zdania nie nadają się na założenia logiczne nauki. W myśl tego ujęcia „opierać się na założeniach” znaczy tyle, co „, $B$ opiera się na $A$ jako na założeniu, o ile $A$ jest racją logiczną $B[\ldots]$ lub też znaczy, że $A$ jest presupozycją $B$ ” (WoléNSKI, „O tak zwanych...”, s. 10).

W myśl prezentowanego tu ujęcia, co warto raz jeszcze podkreślić, filozoficznymi założeniami nauki są takie zdania, które przyjmowane sa jeszcze przed przystapieniem do badań naukowych. Są to przede wszystkim przekonania dotyczące: natury badanej rzeczywistości (znakomitym przykładem jest tu Popperowska idea metafizycznych programów badawczych: por. Karl R. Popper, Quantum Theory and the Schism in Physics: From the Postscript to the Logic of Scientific Discovery, ed. W.W. Bartley III, Rowman and Littlefield, Totowa, New Jersey 1982, s. 159-211; Karl R. Popper, Nieustanne poszukiwania. Autobiografia intelektualna, przeł. Adam Chmielewski, Wydawnictwo Znak, Kraków 1997, s. 235-238) i dopuszczalnych sposobów jej badania (por. np. KILIAN, „Geneza idei...”, s. 139-142). Innym przykładem założeń metafizycznych jest na przykład 
wielokrotnie była rozpoznawana. Oto kilka przykładów:

Przyrodnicy sądzą, że uwalniają się od filozofii, gdy ją ignorują albo wyklinają. [...] niezależnie od tego, co o sobie sądzą, ulegają filozofii. ${ }^{28}$

Mimo tego, że teza ta ma już dość długą historię, to wciąż jeszcze nie jest powszechnie akceptowana, gdyż brak filozoficznych założeń wciąż uznawany jest za pozytywną cechę teorii naukowych. ${ }^{29}$ Jeśli, zgodnie z mocno już przestarzałym podejściem, fakty i logika są jedynymi czynnikami, które wpływają na treść twierdzeń naukowych, to wszystkie inne czynniki deformująco wpływają na naukę. ${ }^{30}$

Mit Racjonalności. Nie odzwierciedla on przekonania, że nasze racjonalne metody badania świata są po prostu towarzyskim konwenansem niektórych ekscentryków. Wyraża coś, co nas transcenduje. Tak jak wszystkie mity, Mit Racjonalności nie może być racjonalnie uzasadniony, ponieważ każda argumentacja już zakłada ten mit.

George V. Coyne and Michael (Michał) Heller, A Comprehensible Universe: The Interplay of Science and Theology, Springer-Verlag, New York 2008, s. 8.

Zaś przykładem tych decyzji metodologicznych jest następująca teza:

Jeżeli — przynajmniej roboczo — zgodzimy się wszechświatem nazywać wszystko, do czego można sięgnąc matematyczno-empiryczną metodą, to [...] [podstawowa] zasada metodologiczna przybiera postać postulatu domagającego się, by wszechświat wyjaśniać samym wszechświatem. W tym sensie wyjaśnienia naukowe są „ostateczne”, gdyż w ramach metody nie dopuszczają żadnych innych wyjaśnień.

Michał Heller, Ostateczne wyjaśnienia wszechświata, Universitas, Kraków 2008, s. 15 [wyróżnienie w oryginale].

${ }^{28}$ Fryderyk EnGels, Dialektyka przyrody, przeł. Tadeusz Zabłudowski, Państwowe Wydawnictwo Naukowe, Warszawa 1979, s. 244-245. Por. też Włodzimierz Iljicz Lenın, Dzieła. Tom 14. 1908 (Materializm a empiriokrytycyzm), przekład (anonimowy) z czwartego wydania rosyjskiego przygotowanego przez Instytut Marksa-Engelsa-Lenina przy KC WKP(b), Książka i Wiedza, Warszawa 1955, s. 156, 408.

${ }^{29}$ Por. w tej sprawie np. uwagi WoleńSKIEGO, „O tak zwanych...”, s. 8; Kazimierza JodKowSKIEGO, „Filozoficzna natura sporu ewolucjonizm-kreacjonizm. Refleksje po lekturze tekstu Phillipa E. Johnsona”, Na Poczatku ... 2000, nr 7-8 (131-132), s. 212-217 [211-217], https://tiny.pl/gzp cc (16.01.2019); Phillipa E. Johnsona, „Co to jest darwinizm?”, przeł. Kazimierz Jodkowski, Problemy Genezy 2010, t. 18, s. 111-112 [103-112]; Jonathana BARTLETTA, „Filozoficzne wady naturalizmu metodologicznego i perspektywy na przyszłość”, przeł. Dariusz Sagan, Filozoficzne Aspekty Genezy 2017, t. 14, s. 57 [53-87], https://tiny.pl/thd7j (16.01.2019).

${ }^{30}$ Por. Feyerabend, „Problems of Empiricism...”, s. 227-228; Kazimierz Jodkowski, „Z jakim 
Nauka sama w sobie nie zawiera żadnego celu, żadnego ideału; nie wyznacza go immanentnie ani jej struktura, ani jej czynności, ani jej treść, ani jej pochodzenie. Ideał, sens i cel my w nią wnosimy; a stawiamy go już zawsze w myśl pewnych założeń pozanaukowych, filozoficznych. ${ }^{31}$

Przykładowo to, czego szukać będziemy dzięki przyjmowanym przez nas teoriom, jest wypadkową celu, jaki uprzednio przyjmiemy. Zakładane w badaniu naukowym standardy (na przykład matematyzowalności świata) ${ }^{32}$ czy reguły (na przykład ignorowania anomalii) mają sens jedynie w świecie charakteryzującym się określoną strukturą. ${ }^{33}$

Linie partyjne nie ograniczają się do polityki, występują też dokładnie w samym centrum nauki. Są tam ukryte jako „fakty eksperymentalne”. ${ }^{34}$

Fakt — o czym już wspominano przy okazji analiz poprzedniego (2.2) argumentu - jak się od dość dawna powszechnie przyjmuje, jest wytworem interpretacji. Zaś te ostatnie, jak również wielokrotnie podkreślano, nie są wyłącznie efektem wiernego podążania za faktami i logiką. ${ }^{35}$ Są one w dużym stopniu zależne „od wcześniej przyjętego punktu widzenia”. ${ }^{36}$

W każdym państwie, również w demokratycznym, istnieje wpływ wartości zewnętrznych na naukę, wartości pochodzących ze świata polityki, ideologii czy panującej reli-

relatywizmem bezskutecznie walczy Wojciech Sady? (Głos w dyskusji)", w: Jan PoмоRSкі (red.), Wartość relatywizmu jako postawy poznawczej, Realizm. Racjonalność. Relatywizm, t. 11, Wydawnictwo UMCS, Lublin 1989, s. 123 [123-146].

${ }^{31}$ Joachim Metallmann, „Nauka, pogląd na świat, filozofia”, odbitka z Przeglądu Wspótczesnego 1939, nr 5-7, s. 29 [1-49], https://tiny.pl/gzn7n (23.11.2018).

${ }^{32}$ Por. np. Eugene P. Wigner, „Niepojęta skuteczność matematyki w naukach przyrodniczych”, przeł. Jacek Dembek, Zagadnienia Filozoficzne w Nauce 1991, vol. 13, s. 6 [5-18], https://tiny.pl/txr8z (16.01.2019).

${ }^{33}$ Por. Paul K. Feyerabend, Przeciw metodzie, przeł. Stefan Wiertlewski, Wydawnictwo SIEDMIORÓG, Wrocław 1996, s. 234.

${ }^{34}$ Paul K. Feyerabend, „Dialectical Materialism and the Quantum Theory”, Slavic Review 1966 , vol. 25 , no. 3 , s. 415 [414-417].

${ }^{35}$ Por. np. Thomas S. KuHn, Struktura rewolucji naukowych, przeł. Helena Ostromęcka i Justyna Nowotniak, Aletheia, Warszawa 2001, s. 76-77.

${ }^{36}$ Edouard Le Roy, „Nauka i filozofia”, przeł. Marcelina Zuber, w: SzLachCic, Filozofia nauki..., s. 109-110 [99-124]. 
gii. Wartości te ograniczają zakres badań, a nawet zmieniają treść orzeczeń naukowych. ${ }^{37}$

Obecność tego typu wartości nie musi być zawsze waloryzowana pozytywnie, ${ }^{38}$ gdyż, jak powszechnie wiadomo, na przykład niektóre decyzje polityczne w zdecydowanie negatywny sposób wpływały na rozwój nauki. ${ }^{39}$ Wskazywanie na taką obecność nie prowadzi do jej waloryzowania.

Pojawiały się też różne diagnozy „nieredukowalnej obecności” ${ }^{40}$ filozofii w nauce. $Z$ jednej strony nonszalancko sugerowano, by wyraźnie opowiedzieć się po „właściwej” stronie, wybrać „najlepsze” założenia:

Albo konsekwentny do ostatka materializm, albo kłamstwo i mętlik idealizmu filozoficznego. ${ }^{41}$

Z drugiej strony rozważnie proponowano badania, dzięki którym zrozumieć można znaczenie i rolę rozmaitych założeń w poznaniu naukowym. Sugerowano, aby badać owe założenia, świadomie przyjmując odmienny wobec aktualnie przyjmowanych założeń punkt widzenia. ${ }^{42}$ Następstwem takich badań może być wykrycie słabych punktów analizowanych ujęć.

Przestrzegano też przed próbami wykluczania tego typu założeń z dyskursu naukowego. Jednym z następstw takiego wykluczenia jest nieświadome uwikła-

\footnotetext{
${ }^{37}$ Kazimierz Jodkowski, „Wartości poznawcze w nauce. Wystąpienie w panelu dyskusyjnym”, https://tiny.pl/thmzg (23.11.2018). Por. też LekKa-Kowalik, „Nauka wolna od wartości...”.

${ }^{38}$ Por. np. Woleński, „O tak zwanych...”, s. 14; Hans Kelsen, „Science and Politics”, The American Political Science Review 1951, vol. 45, no. 3, s. 646-647 [641-661].

${ }^{39}$ Przykładowo

na sesji w dniach 31 VII - 7 VIII 1948 r. Wszechzwiązkowa Akademia Nauk Rolniczych im. W.I. Lenina przyjęła łysenkizm jako jedyną prawdziwą teorię w naukach biologicznych i rolniczych uprawianych w Związku Socjalistycznych Republik Radzieckich.

Piotr KöHLER, „Łysenkizm w botanice polskiej”, Kwartalnik Historii Nauki i Techniki 2008, t. 53 , nr 2, s. 85 [83-161].

${ }^{40}$ Por. Kilian, „Geneza idei...”, s. 140.

${ }^{41}$ Lenin, Dziela. Tom 14..., s. 386.

${ }^{42}$ Feyerabend, „Dialectical Materialism...”, s. 415.
} 
nie się w inny system wartości:

Zapytać można, kto zagwarantuje, że odrzucając istniejące ideologie, nie staniemy się ofiarami jeszcze gorszej ideologii. ${ }^{43}$

Innym następstwem jest ponowne przyjęcie zarzuconego już ideału metody naukowej jako neutralnego arbitra rozstrzygania sporów w nauce:

Ideał nauki wolnej od wartości zakłada istnienie Metody Naukowej [...], która w niezawodny sposób prowadziłaby od zebranych danych do sformułowania praw czy teorii i która neutralizowałaby postawy wartościujące zajmowane przez naukowców. Okazuje się jednak, że wszelkie próby sformułowania takiej metody spełzły na niczym, a w proces badawczy zaangażowane są decyzje badaczy, co do tego, które dane wziąć pod uwagę, który układ eksperymentalny jest właściwy, która z konkurencyjnych teorii warta jest zaakceptowania itd. ${ }^{44}$

\section{Kolejnym jeszcze następstwem jest zahamowanie wzrostu wiedzy:}

Gdyby [...] uczeni w każdej sytuacji podejmowali jednakowe decyzje na podstawie ścisłych i jednoznacznych reguł, to nauka mogłaby zabrnąć w ślepy zaułek. Dzięki temu, że wartości naukowe nie wyznaczają jednoznacznie postępowania, istnieje pewien rozrzut decyzyjny w społecznościach uczonych, a przez to szansa, że w trudnych sytuacjach znajdzie się jakieś dobre rozwiązanie. Istnieje tu ścisła analogia do zróżnicowania mutacji u organizmów żywych, które pozwala przetrwać w zmieniającym się środowisku. Zróżnicowanie postępowania uczonych, opierających się na wartościach, jest więc dla nauki korzystne, choć jest to odstępstwo od innej wartości, od ideału ścisłości. ${ }^{45}$

2.4. Jeszcze inny argument głosi, że bezkrytyczne przyjmowanie naturalizmu może doprowadzić do sytuacji, w której większym zaufaniem obdarzone

\footnotetext{
${ }^{43}$ Paul K. Feyerabend, „The Theatre as an Instrument of the Criticism of Ideologies: Notes on Ionesco", Inquiry 1967, vol. 10, s. 309 [298-312].

${ }^{44}$ LekKa-Kowalik, „Nauka wolna od wartości...”. Por. też Henry H. Bauer, Scientific Literacy and the Myth of the Scientific Method, University of Illinois Press, Urbana and Chicago 1994, s. 33-41; Diderik Batens, „Pluralism in Scientific Problem Solving: Why Inconsistency Is No Big Deal”, Humana. Mente Journal of Philosophical Studies 2017, vol. 32, s. 151-155 [149177], https://tiny.pl/thmzk (23.11.2018). Paul K. Feyerabend, „Reply to Criticism: Comments on Smart, Sellars and Putnam”, w: Feyerabend, Philosophical Papers. Vol. 1..., s. 104 przyp. 1 [104$131]$.

${ }^{45}$ JoDkowski, „Wartości poznawcze w nauce...”.
} 
zostaną, pozbawione należytego wsparcia empirycznego, spekulacje niż nienaturalistyczne wyjaśnienia ex definitione wykluczane z obszaru nauki. ${ }^{46}$

Argument ten zakłada, że da się niearbitralnie określić okres czasu, po którego upływie zrezygnować należy z ujęcia teoretycznego, gdyż nie przynosi ono zamierzonych efektów. Jednak wielokrotnie podkreślano, że takiego zabiegu przeprowadzić się nie da ${ }^{47}$ gdyż nawet najbardziej przytłaczające trudności, z jakimi boryka się dane ujęcie, mogą zostać przezwyciężone. ${ }^{48}$ Wyznaczanie takich limitów czasowych napotyka też na inną trudność. Jeśli pozwalało się czekać jakiemuś ujęciu teoretycznemu, to dlaczego nie poczekać jeszcze dłużej? ${ }^{49}$ Zauważono również, że

proliferacja i uporczywość nie są własnościami kolejnych etapów rozwoju nauki, lecz zawsze są współobecne. ${ }^{50}$

2.5. Naturalizm metodologiczny, zgodnie z kolejnym argumentem, opiera się na „,wykluczającej logice". ${ }^{51}$

\footnotetext{
${ }^{46}$ Por. Dariusz SAGAN, „Naturalizm metodologiczny — konieczny warunek naukowości?”, Roczniki Filozoficzne 2013, t. 61, nr 1, s. 83 [73-91], https://tiny.pl/q33sb (23.11.2018); SAGAN, „Naturalizm metodologiczny a zagadnienie...”, s. 172.

${ }^{47}$ Por. np. Paul K. Feyerabend, „Fantazje platońskie”, w: Paul K. Feyerabend, Dialogi o wiedzy, przeł. Justyna Nowotniak, Fundacja Aletheia, Warszawa 1999, s. 48 [5-76]; Paul K. FeYerABEND, „Ku pocieszeniu specjalisty”, w: Feyerabend, Jak być dobrym empirystą..., s. 207-208 [200-250]; Paul K. Feyerabend, „Science, Freedom, and the Good Life”, The Philosophical Forum 1968, vol. 1, no. 2, s. 131-132 [127-135]; Kazimierz JodKowski, „Zasadnicza nierozstrzygalność sporu ewolucjonizm-kreacjonizm”, Przeglad Filozoficzny - Nowa Seria 2012, nr 3 (83), s. 214 [201-222], https://tiny.pl/gkf57 (23.11.2018).

${ }^{48}$ Por. Paul K. Feyerabend, „Outline of a Pluralistic Theory of Knowledge and Action”, w: Paul K. Feyerabend, Philosophical Papers. Vol. 3. Knowledge, Science and Relativism, ed. John Preston, Cambridge University Press, Cambridge - New York - Melbourne - Madrid - Cape Town — Singapore - Sao Paulo 1999, s. 108 [104-111].

${ }^{49}$ Paul K. Feyerabend, „Against Method: Outline of an Anarchistic Theory of Knowledge”, w: Michael Radner and Stephen Winokur (eds.), Analyses of Theories and Methods of Physics and Psychology, Minnesota Studies in the Philosophy of Science, vol. 4, University of Minnesota Press, Minneapolis 1970, s. 77-78 [17-130]. Por. też Feyerabend, „Ku pocieszeniu...”, s. 222-223.

${ }^{50}$ Feyerabend, „Ku pocieszeniu...”, s. 217.

${ }^{51}$ Por. Stephen C. MeYER, „DNA a pochodzenie życia. Informacja, specyfikacja i wyjaśnienie", przeł. Dariusz Sagan, Filozoficzne Aspekty Genezy 2005/2006, t. 2/3, s. 214 [133-215], https://tiny.pl/q3mlb (23.11.2018). Por. też William A. Dembski, „Odmiany naturalizmu. Czy któ-
} 
Tak więc ta forma naturalizmu „ogranicza badania naukowe” ${ }^{52}$ i, jako taka, jest błędną postawą, ponieważ a priori unieważnia pewne możliwości. ${ }^{53}$

Ten argument jest bardzo trafny. Widoczne jest to na trzech płaszczyznach.

Poszukując wyjaśnień dla badanych zjawisk, należy brać pod uwagę wszelkie logicznie możliwe stany rzeczy:

raś forma naturalizmu jest zgodna z teorią inteligentnego projektu?", przeł. Dariusz Sagan, $\mathrm{Na}$ Poczatku... 2005, nr 1-2, s. 47 [45-54], https://tiny.pl/xhkg8 (23.11.2018); Jonathan BARTLETT, „Philosophical Shortcomings of Methodological Naturalism and the Path Forward”, w: Jonathan Bartlett and Eric Holloway (eds.), Naturalism and Its Alternatives in Scientific Methodologies: Proceedings of the 2016 Conference on Alternatives to Methodological Naturalism, Blyth Institute Press, Broken Arrow, Oklahoma 2017, s. 16 [13-37], https://tiny.pl/gkdb2 (23.11.2018); BartLetT, „Filozoficzne wady naturalizmu...”, s. 55-56; Jonathan BartLETt and Eric Holloway, „Introduction”, w: Bartlett and Holloway (eds.), Naturalism and Its Alternatives..., s. 4 [1-9]; Philip E. Johnson, „The Intelligent Design Movement: Challenging the Modernist Monopoly on Science", w: William A. Dembski and James M. Kushiner (eds.), Signs of Intelligence: Understanding Intelligent Design, Brazos Press, Grand Rapids 2001, s. 31-32 [25-41]; Phillip E. JohNson, Sąd nad Darwinem, przeł. Robert Piotrowski, Oficyna Wydawnicza Vocatio, Warszawa 1997, s. 147; Brand, „Naturalizm i jego rola...”, s. 55.

${ }^{52}$ Dembski, „Powrót projektu...”, s. 327. Por. też MeYer, „DNA a pochodzenie życia...”, s. 214; Tomasz Krause, „,Filozoficzne aspekty tzw. «afery Kansas»”, Filozoficzne Aspekty Genezy 2004, t. 1, s. 144 [143-224], https://tiny.pl/g2863 (23.11.2018); Nancy PearceY, „Ewolucjonizm po Darwinie”, przeł. Kazimierz Jodkowski, w: JodKowski, Metodologiczne aspekty..., s. 445 [431-446].

${ }^{53}$ Jodkowski, „Rozpoznawanie genezy...”, s. 190. Por. też Kazimierz JodKowski, Spór ewolucjonizmu z kreacjonizmem. Podstawowe pojęcia i poglądy, Biblioteka Filozoficznych Aspektów Genezy, t. 1, Wydawnictwo MEGAS, Warszawa 2007, s. 16, https://tiny.pl/qzq8j (23.11.2018); Kazimierz JoDKowski, „Wstęp do teorii inteligentnego projektu”, Fronda 2012, nr 63, s. 21 [1632], https://tiny.pl/gkfbn (23.11.2018); Stephen C. MeYER, „The Use and Abuse of Philosophy of Science: A Response to Moreland”, Perspectives on Science and Christian Faith 1994, vol. 46, no. 1, s. 21 [19-21], https://tiny.pl/h2wcm (23.11.2018); Robert C. O'Connor, „Nauka przed sądem: analiza racjonalności naturalizmu metodologicznego", przeł. Joanna Popek i Grzegorz Rogula, Filozoficzne Aspekty Genezy 2014, t. 11, s. 124-125 [95-131], https://tiny.pl/xh8tq (23.11. 2018); McMullin, „Odmiany naturalizmu...”, s. 115-116; Robert A. Delfino, „Naturalizm metodologiczny i ewolucja”, przeł. Rafał Lizut, w: Piotr JARoszYŃSKI (red.), Ewolucjonizm czy kreacjonizm, Przyszłość Cywilizacji Zachodu, Fundacja „Lubelska Szkoła Filozofii Chrześcijańskiej”, Lublin 2008, s. 144 [137-156]; Meyer, „DNA a pochodzenie życia...”, s. 213-214; Dariusz SAGAN, Spór o nieredukowalną złożoność układów biochemicznych, Biblioteka Filozoficznych Aspektów Genezy, t. 5, Wydawnictwo MEGAS, Warszawa 2008, s. 20, https://tiny.pl/qzq8p (24. 11.2018); William A. Dembski, „On the Very Possibility of Intelligent Design”, w: James Porter 
Dzięki poszukiwaniu logicznych raczej niż naturalistycznych wyjaśnień nauka pozostaje otwarta na [taką] możliwość, że aktualna wiedza może wskazywać na wniosek, że same siły przyrody nie wystarczają do wyjaśnienia niektórych zjawisk. ${ }^{54}$

$\mathrm{W}$ innym razie

istnieje ryzyko przeoczenia najlepszego wyjaśnienia, ${ }^{55}$

co [...] może prowadzić do powszechnego przyjęcia fałszywego obrazu świata. ${ }^{56}$

Oczywiście nie od dziś wiadomo, że możliwość przyjęcia fałszywego obrazu świata jest nierozerwalnie związana ze wszystkimi badaniami naukowymi. Jednak, na co trudno nie przystać, aprioryczne eliminowanie określonych wyjaśnień tylko dlatego, że nie są one zgodne z powszechnie przyjmowaną perspektywą metodologiczną, takie prawdopodobieństwo zwiększa.

$Z$ jednej strony trudno zaprzeczyć, że pod szyldem nieprzeoczenia najlepszego wyjaśnienia swoje badania prowadził Darwin. Szereg sukcesów, którymi poszczycić się może podejście naturalistyczne, wziął się właśnie z tego, że pod-

Moreland (ed.), The Creation Hypothesis: Scientific Evidence for an Intelligent Designer, Inter Varsity Press, Downers Grove 1994, s. 131 [113-139]; BEHE, „Nieredukowalna złożoność...”, s. 76; Johnson, „The Intelligent Design Movement...”, s. 31-32; Dariusz Sagan, „Problem religijnego charakteru teorii inteligentnego projektu”, Studia Philosophica Wratislaviensia 2011, vol. VI, fasc. 4, s. 56 [55-74], https://tiny.pl/q336q (24.11.2018); SAGAN, „Teoria inteligentnego projektu...", s. 337.

${ }^{54}$ Paul D. Ackerman and Bob Williams, Kansas Tornado: The 1999 Science Curriculum Standards Battle, Institute for Creation Research, El Cajon, California 1999, s. 43 (cyt. za: KRAUSE, ,Filozoficzne aspekty...”, s. 177). Por. też Dembski, „Odmiany naturalizmu...”, s. 48; Krause, „Filozoficzne aspekty...”, s. 144; Pearcey, „Ewolucjonizm po Darwinie...”, s. 445.

${ }^{55}$ O’Connor, „Nauka przed sądem...”, s. 106. Por. też MeYer, „The Use and Abuse...”.

${ }^{56}$ SAGAN, „Naturalizm metodologiczny - konieczny...”, s. 84. Por. też SAGAN, „Naturalizm metodologiczny a zagadnienie...”, s. 173; Dariusz SAGAN, Metodologiczno-filozoficzne aspekty teorii inteligentnego projektu, Biblioteka Filozoficznych Aspektów Genezy, t. 6, Instytut Filozofii Uniwersytetu Zielonogórskiego, Zielona Góra 2015, s. 269, https://tiny.pl/g7m72 (24.11.2018); DARIUSZ SAGAN, „Spór o użyteczność teorii inteligentnego projektu dla nauki”, Kultura i Edukacja 2013, nr 3 (96), s. 33 [28-49], https://tiny.pl/xhhg3 (24.11.2018); Del Ratzsch, Science \& Its Limits: The Natural Sciences in Christian Perspective, InterVarsity Press, Downers Grove, Illinois 2000, s. 105; Del RATzsch, „Teologia naturalna, naturalizm metodologiczny i «żółwie do samego dołu»", przeł. Dariusz Sagan, Filozoficzne Aspekty Genezy 2016, t. 13, s. 125 [119-152], https://ti ny.pl/thgbx (24.11.2018); O’ConNor, „Nauka przed sądem...”, s. 105; Delfino, „Naturalizm metodologiczny...", s. 144-145. 
ważone zostało dominujące $\mathrm{w}$ czasach angielskiego przyrodnika podejście do wyjaśniania pochodzenia gatunków drogą odwoływania się do Boskiego Projektanta. $Z$ drugiej zaś strony to, że jakiemuś punktowi widzenia dano już szansę, której jego zwolennicy nie wykorzystali, nie świadczy o tym, że nie uda się go w przyszłości zmodyfikować i obronić. Dobrymi przykładami są tu poważne potraktowanie i rozwinięcie przez Kopernika - utrzymywanej przez, uznawanego za szaleńca, Filolaosa z Tarentu — hipotezy ruchomej Ziemi lub przyjęcie przez Newtona skompromitowanej (qualitates occultae) hipotezy, zakładającej istnienie siły przyciągającej, działającej na odległość poprzez próżnię. Nie należy zatem definitywnie eliminować starych teorii tylko dlatego, że w chwili obecnej uznane zostały za nieaktualne — łatwiej jest rozwijać jakieś stanowisko niż wymyślać coś od nowa. ${ }^{57}$

Trudno też nie zgodzić się z tezą, w myśl której naturalizm, który dobrze funkcjonuje w obrębie pewnych dziedzin nauki (na przykład w fizyce), w innych jej dziedzinach może ograniczać badania. ${ }^{58}$

2.6. W myśl ostatniego, badanego $\mathrm{w}$ tej grupie argumentu naturalizm metodologiczny nie powinien być uznawany nawet za tymczasową zasadę, ponieważ „nie jesteśmy pewni”, że „to, co nadnaturalne, nie istnieje”. ${ }^{59}$

$\mathrm{Z}$ pewnością, jak powszechnie wiadomo, nauka rozstała się wraz z upowszechnieniem się idei fallibilizmu i hipotetyzmu. W powyższym argumencie nie chodzi, jak się zdaje, o to, by naukę ograniczać do zbioru twierdzeń pewnych. Zauważono też, iż

w wielu przypadkach również nie jesteśmy pewni, że istnieje nawet to, co naturalne (historia nauki pokazuje, że wiele przedmiotów teoretycznych postulowanych w ramach teorii naukowych okazało się fikcjami — cieplik, flogiston, eter...), ${ }^{60}$

\footnotetext{
${ }^{57}$ Por. Krzysztof J. Kilian, „Wzrost wiedzy a zasada tolerancji”, w: Jakub Michalczenia, Jadwiga Mızı́śsa i Katarzyna Ossowska (red.), Poszukiwania filozoficzne. T. 1. Nauka. Prawda. Panu Profesorowi Józefowi Dębowskiemu w darze, Instytut Filozofii Uniwersytetu WarmińskoMazurskiego w Olsztynie, Olsztyn 2014, s. 161-162 [155-173], https://tiny.pl/tx9m4 (16.01. 2019). s. 214.

${ }^{58}$ Por. BRand, „Naturalizm i jego rola...”, s. 20; MeYER, „DNA a pochodzenie życia...”,

${ }^{59}$ Delfino, „Replacing Methodological Naturalism...”.

${ }^{60}$ Fragment jednej z uwag anonimowego recenzenta do mojego tekstu.
} 
sugerując tym samym, że brak pewności nie może być uznawany za potencjalną nawet miarę tego, co istnieje.

Taki komentarz do powyższego argumentu jest jednak obosieczną bronią. Nie jesteśmy bowiem też pewni, że porzucone przez naukę przedmioty teoretyczne są fikcjami. W myśl jednego z podejść przedmioty teoretyczne porzucane są przede wszystkim z powodów filozoficznych, bo akceptacja ich istnienia nie jest zgodna z przyjmowaną perspektywą metafizyczną lub metodologiczną. ${ }^{61}$ Tak właśnie, zdaniem Johna Stewarta Bella, było z eterem, który, w jego przekonaniu, przedwcześnie został porzucony z powodów par excellence

filozoficznych. To, czego nie można zaobserwować, nie istnieje. [Porzucono go] również z uwagi na prostotę, ponieważ Einstein wykazał, że porzucając ideę eteru otrzymujemy teorię prostszą i bardziej elegancką. [...] Myślałem o powrocie do koncepcji eteru, ponieważ doświadczenie EPR sugeruje, że mamy tu do czynienia z ukrytymi oddziaływaniami rozchodzącymi się szybciej niż światło. ${ }^{62}$

Istnieje tu pewna analogia do podejść naturalistycznych i antynaturalistycznych. Podejścia te, jak się dość powszechnie zauważa, wybierane są na ogół ze względu na preferencje światopoglądowe. ${ }^{63}$ Przykładowo, mówi się, że naturalizm metodologiczny

jest najbardziej ekonomicznym podejściem [do wyjaśniania] ze znanych — ogranicza się do wyjaśnień, które przyjmują minimalną ilość założeń ontologicznych — i, jako taki, prowadzi do przyjęcia ekonomicznego światopoglądu, który jest atrakcyjny dla

\footnotetext{
${ }^{61}$ Por. np. Feyerabend, Przeciw metodzie..., s. 234; Paul K. Feyerabend, „The Problem of the Existence of Theoretical Entities”, w: Feyerabend, Philosophical Papers. Vol. 3..., s. 16-17 [1649].

${ }^{62}$ Wypowiedź Johna Bella przytaczana za: J.R. Brown i P.C.W. Davies, Duch w atomie. Dyskusja o paradoksach teorii kwantowej, przeł. Piotr Amsterdamski, Wydawnictwo CIS, Warszawa 1996, s. 68.

${ }^{63}$ Por. np. Stephen Jay Gould, „Epizodyczny charakter zmian ewolucyjnych”, w: Stephen Jay Gould, Niewczesny pogrzeb Darwina. Wybór esejów, przeł. Nina Kancewicz-Hoffman, $B i$ blioteka Myśli Współczesnej, Państwowy Instytut Wydawniczy, Warszawa 1991, s. 184, 189 [183-200]; Michael Ruse, Darwinism Defended: A Guide to the Evolution Controversies, Addison-Wesley, Reading, Massachusetts 1982, s. 280; Alvin Plantinga, „Naturalizm metodologiczny?", przeł. Radosław Plato, Filozoficzne Aspekty Genezy 2014, t. 11, s. 49 [37-93], https://tiny. pl/xh89b (24.11.2018); Anna LemaŃsKA, „Ewolucja jako realizacja projektu?”, Filozofia i Nauka 2015, t. 3, s. 357 [353-358], https://tiny.pl/tqw4j (24.12.2018).
} 
ludzi nauki. ${ }^{64}$

Argument ten (2.6) przypomina argument poprzedni (2.5) i brzmi bardzo rozsądnie, gdy przyjmiemy, że prowadzi on jedynie do przekonania, w myśl którego nie należy z góry wykluczać takich alternatywnych rozwiązań, które opierają się na innych niż metodologiczny naturalizm epistemicznych układach odniesienia. ${ }^{65}$

Aposterioryczne unieważnianie wyjaśnień jest bardziej obiecujące od unieważniania apriorycznego. ${ }^{66}$ Lepiej wiedzieć „po zbadaniu sprawy, nie przed”, że niektóre wyjaśnienia są nietrafne. ${ }^{67} \mathrm{I}$ dlatego właśnie należy szukać przyczyn dla wyjaśnianych zjawisk bez apriorycznego wykluczania logicznie możliwych rozwiązań. ${ }^{68}$

W podsumowaniu tego argumentu zaznaczyć jednak należy, że odmawianie wymogowi naturalizmu metodologicznego charakteru nawet tymczasowej zasady jest grubym nieporozumieniem. Bez cienia wątpliwości wskazać można, że podążanie za tą zasadą miało szereg pozytywnych skutków dla nauki. Problem z tą zasadą, podobnie jak ze wszystkimi innymi, co zauważono już czas jakiś temu, pojawia się wtedy, gdy przekształcona zostanie w bezwzględną dyrekty-

\footnotetext{
${ }^{64}$ Ronald G. Larson, „O argumencie z Boga w lukach wiedzy raz jeszcze”, przeł. Joanna Popek, Filozoficzne Aspekty Genezy 2012, t. 9, s. 200 [199-220], https://tiny.pl/xhzg7 (24.11.2018).

${ }^{65}$ Delfino łączy swój argument z zasadą metodologicznej neutralności. Połączenie to sprawia, że argument ten może być odczytany inaczej, jako propozycja powstrzymywania się od wy głaszania przekonań na temat sposobu istnienia świata. Zagadnienie to analizuję w punkcie 8.3.

${ }^{66} \mathrm{O}$ takim sposobie unieważniania wyjaśnień mówi warunek Jodkowskiego. W myśl tego warunku tam, gdzie wprowadza się wyjaśnienia antynaturalistyczne, należy wprzódy przedstawić mocną argumentację, zgodnie z którą wyjaśnienia naturalistyczne nie są możliwe (por. JoDKowski, Metodologiczne aspekty..., s. 313; Wojciech SADY, „Dlaczego kreacjonizm «naukowy» nie jest naukowy i dlaczego nie prowadzi do teizmu?", Przeglad Filozoficzny - Nowa Seria 2001, nr 1 (37), s. 226 [213-228], https://tiny.pl/gdw91 (21.12.2018); Kazimierz Jobkowski, „Ruch kreacjonistyczny jest elementem pluralizmu naukowego", Przeglad Filozoficzny - Nowa Seria 2001, nr 1 (37), s. 246-247 [241-253], https://tiny.pl/gdw95 (21.12.2018); JoркоwsкI, Spór ewolucjonizmu z kreacjonizmem..., s. 182-183; KILIAN, „Argumenty na rzecz naturalizmu...”, s. 46-50.

${ }^{67}$ Por. Jodkowski, Spór ewolucjonizmu z kreacjonizmem..., s. 16.

${ }^{68}$ Por. Michael J. BEHE, „Filozoficzne zarzuty stawiane hipotezie inteligentnego projektu: odpowiedź na krytykę", przeł. Dariusz Sagan, Filozoficzne Aspekty Genezy 2004, t. 1, s. 130 [115139], https://tiny.pl/gt9nw (24.11.2018).
} 
wę, którą stosować należy bez względu na okoliczności. ${ }^{69}$

\section{Naturalizm utrudnia wspólzawodnictwo w nauce}

Takie utrudnianie swobodnej konkurencji poglądów manifestuje się w tym, że promuje on „naukowe lenistwo" i wyklucza wszelkie nienaturalistyczne wyjaśnienia. ${ }^{70}$

Lenistwo to przejawiać ma się w tym, że sugeruje się, iż zbyteczne jest poszukiwanie alternatywnych względem naturalizmu rozwiązań. ${ }^{71}$ Jednak argument ten jest obosieczną bronią. Zwolennicy naturalizmu wysuwają podobny zarzut w stosunku do swoich adwersarzy. Ci ostatni przyjmują wyjaśnienia antynaturalistyczne wtedy, gdy zawodzą wyjaśnienia naturalistyczne. ${ }^{72}$

Bezwzględnie utrzymywany naturalizm utrudnia współzawodnictwo nie dlatego, że promuje naukowe lenistwo. Utrudnia je, o czym była już mowa podczas analiz poprzedniego argumentu, dlatego, że apriorycznie wyklucza alternatywne (bazujące na innych niż metodologiczny naturalizm epistemicznych układach odniesienia) podejścia do wyjaśniania.

\section{Naturalizm jest częścią pewnej tradycji, która pochopnie zostala zabsolutyzowana}

Argument, w myśl którego

nauka w pewien sposób nieodzownie wymaga [...] zasady naturalizmu metodologicznego, ${ }^{73}$

\footnotetext{
${ }^{69}$ Por. Feyerabend, Przeciw metodzie..., s. 30.

${ }^{70}$ Por. Delfino, „Zastąpić metodologiczny naturalizm...”, s. 11. Por. też Ratzsch, „Teologia naturalna...", s. 127-130.

${ }^{71}$ Por. Delfino, „Zastąpić metodologiczny naturalizm...”, s. 11; DemBSKI, „Odmiany naturalizmu...", s. 47.

${ }^{72}$ Por. np. Robert T. Pennock, Tower of Babel: The Evidence Against the New Creationism, MIT Press, Cambridge 1999, s. 294.

${ }^{73}$ Plantinga, ,Naturalizm metodologiczny...”, s. 64.
} 
opiera się na oświeceniowym fundamentalizmie epistemologicznym. Ponieważ fundamentalizm ten ,osiadł na mieliźnie”, to i argument ten jest nietrafny. ${ }^{74} \mathrm{Ar}$ gument, o którym mowa, w swoim rozwinięciu przedstawia się następująco. Naturalizm jest częścią oświeceniowego rozumienia relacji wiary do rozumu. Zgodnie $\mathrm{z}$ tym rozumieniem nauka formułuje obiektywne - bazujące jedynie na rozumie i zmysłach, władzach, które są dla wszystkich ludzi identyczne twierdzenia na temat rzeczywistości. Zaś wiara (a za nią religia) jest wyrazem jedynie subiektywnych przekonań. Subiektywne przekonania nie mogą być punktem wyjścia dla nauki. ${ }^{75}$ Tej ostatniej

nie można $[\ldots]$ należycie uprawiać, gdy punktem wyjścia są w jakiejś mierze przekonania lub dogmaty religijne. ${ }^{76}$

Oświeceniowy fundamentalizm krytykowano na wiele sposobów. ${ }^{77}$ Argument powyższy jest nietrafny bez względu na to, czy istnieją absolutne podstawy poznania. Po pierwsze, dlatego, że porzucenie tego rodzaju fundamentalizmu, którego, jako jeden z pierwszych, dokonał Newton, nie szło w parze z akceptacją poglądu, że subiektywne przekonania mogą być punktem wyjścia dla nauki. ${ }^{78}$ Newton nie opierał swoich teorii na pierwszych zasadach i nie uważał, by to dyskwalifikowało jego wyjaśnienia, które, jak długo mniemano, miały charakter demonstratywnie uzasadnionych, apodyktycznie pewnych twierdzeń o rzeczywistości. ${ }^{79}$ Idea fundamentalizmu zastąpiona została zatem ideą certy-

\footnotetext{
${ }^{74}$ Por. Plantinga, „Naturalizm metodologiczny...”, s. 64.

${ }^{75}$ Por. Plantinga, „Naturalizm metodologiczny...”, s. 64. Por. też MeYer, „The Use and Abuse...”; Larson, „O argumencie z Boga...”, s. 204.

${ }^{76}$ Plantinga, ,Naturalizm metodologiczny...”, s. 64.

${ }^{77}$ Dwie najbardziej znane krytyki Kartezjańskiego fundamentalizmu wywodzą się od $\mathrm{Hu}$ me'a (por. David Hume, Traktat o naturze ludzkiej. Tom I. O umyśle, przeł. Czesław Znamierowski, Nakładem Polskiej Akademii Umiejętności, Kraków 1951, s. 250-251) i Gassendiego. Przedstawiona przez tego ostatniego krytyka cogito ergo sum jako pierwszej zasady filozofii rozwinięta została przez Scholza i Łukasiewicza (por. Jan ŁuKASIEwICZ, „Dwaj filozofowie nowożytni: Kartezjusz i Kant”, Filozofia Nauki 1997, t. 5, nr 2, s. 161-163 [159-166]).

${ }^{78}$ Por. Isaac Newton, Matematyczne zasady filozofii przyrody, przeł. Jarosław Wawrzycki, Copernicus Center Press, Kraków 2011, s. 694.

${ }^{79}$ Por. np. Karl R. Popper, „Natura problemów filozoficznych i ich korzenie w nauce”, w: Karl R. PopPer, Droga do wiedzy. Domysły i refutacje, przeł. Stefan Amsterdamski, Biblioteka Wspótczesnych Filozofów, Wydawnictwo Naukowe PWN, Warszawa 1999, s. 164 [117-169].
} 
zmu, uznającego naukę za korpus pewnych i uzasadnionych twierdzeń o rzeczywistości. ${ }^{80}$

Po drugie, dlatego, że ważny jest nie punkt wyjścia, tylko punkt dojścia. Tak naprawdę istotne jest tylko to, jak uzasadnia się własne przekonania, ${ }^{81}$ a nie to, od czego się wychodzi. ${ }^{82}$ To uzasadnienia powinny pozostawać $\mathrm{w}$ zgodzie $\mathrm{z}$ aktualnie akceptowanymi regułami gry naukowej, a nie subiektywnie przyjmowany punkt wyjścia. Dobrymi przykładami są tu Behe i Dembski, którzy utrzymują, że to chrześcijański światopogląd motywował ich do poszukiwań alternatywy

\footnotetext{
${ }^{80}$ Najprawdopodobniej nazwa „certyzm” wywodzi się od Stanisława Kamińskiego (por. Monika WaLCZAK, „Stanisława Kamińskiego poglądy na cel nauki”, Zagadnienia Naukoznawstwa 2011, nr 3 (189), s. 404 [391-405], https://tiny.pl/gztwm [23.11.2018]). Por. też Włodzimierz ZlęBA, „Metafizyka w nauce, nauka w filozofii. Kazimierz Jodkowski i Richard Rorty”, w: Piotr Bylica, Krzysztof J. Kilian, Robert Piotrowski i Dariusz Sagan (red.), Filozofia — nauka - religia. Księga jubileuszowa dedykowana Profesorowi Kazimierzowi Jodkowskiemu z okazji 40lecia pracy naukowej, Oficyna Wydawnicza Uniwersytetu Zielonogórskiego, Zielona Góra 2015, s. $125[115-126])$.

${ }^{81}$ Por. np. Karl R. Popper, „O źródłach wiedzy i niewiedzy”, w: Popper, Droga do wiedzy..., s. 52 [11-57]; Paul K. Feyerabend, The Tyranny of Science, Polity Press, Cambridge UK, Malden USA 2012, s. 41-42.

${ }^{82}$ Istnieje w tej sprawie pogląd przeciwny. Jego zwolennikiem jest Wojciech Sady. Filozof ten przekonaniu, w myśl którego na naukową wartość hipotezy czy teorii nie ma wpływu jej geneza, przeciwstawia przekonanie, zgodnie z którym o naukowej wartości hipotezy świadczy jej związek ze zgromadzoną wprzódy wiedzą o charakterze naukowym. Uzasadnia to w sposób następujący:
}

wiemy, że ani jedno teoretyczne odkrycie nie nastąpiło w próżni, czy to teoretycznej, czy empirycznej. Odkryć dokonywali tylko ci, którzy wcześniej znakomicie opanowali całą wiedzę już wspólnotowo uzyskaną, a do dokonania danego odkrycia niezbędną. Zawsze, zanim ktoś sformułował nowe twierdzenie teoretyczne, dokonywano odpowiednich odkryć eksperymentalnych. Po fakcie zaś można skonstruować rozumowania, spełniające prawa logiki, wiodące od zastanej wiedzy teoretycznej i nowych (uteoretyzowanych) zdań obserwacyjnych do „odkrytego” twierdzenia.

Wojciech SADY, „Czego Kazimierz Jodkowski nie dostrzega, jeśli o odkrycia naukowe chodzi?”, w: Bylica, Kilian, Piotrowski i Sagan (red.), Filozofia - nauka — religia..., s. 64 [59-64], https://tiny.pl/g268h (24.11.2018).

Jednakże mankamentem tego podejścia jest to, że zgodnie z nim najwięcej odkryć powinni dokonywać doświadczeni uczeni, mocno związani z paradygmatem. Zauważono jednak, że sprawy przedstawiają się inaczej. To uczeni młodzi i niedoświadczeni częściej dokonują przewrotów niż ci, którzy „wcześniej znakomicie opanowali całą wiedzę już wspólnotowo uzyskaną”: 
dla darwinizmu. W swoich uzasadnieniach nie korzystają oni jednak z przesłanek religijnych. ${ }^{83}$

\section{Naturalizm jest prowizoryczną zasadą, a nie warunkiem koniecznym uprawiania nauki ${ }^{84}$}

5.1. Na rzecz powyższej tezy argumentuje się, twierdząc, że naturalizm jest jednym z możliwych podejść do nauki, gdyż nie istnieje powszechnie akceptowana definicja tej ostatniej, zatem przyjęcie naturalizmu lub antynaturalizmu, podobnie jak każdej innej decyzji metodologicznej, jest kwestią arbitralną:

Każdy naukowiec [...] dokonuje sam rozstrzygnięcia, czy poszukuje wyjaśnień i formułuje teorie na gruncie ścisłego naturalizmu, czy też będzie dopuszczał także wyjaśnienia [...] [antynaturalistyczne]. ${ }^{85}$

Każda nowa interpretacja przyrody, czy będzie to odkrycie, czy teoria, powstaje najpierw w umyśle jednego lub kilku badaczy. To oni właśnie pierwsi potrafią inaczej spojrzeć na naukę i na świat. Sprzyjają temu zazwyczaj dwie okoliczności, które wyróżniają ich w obrębie danej grupy zawodowej. Po pierwsze, uwaga ich skupiona jest na problemach, które brzemienne są w kryzys. Po drugie, są to zazwyczaj ludzie młodzi albo od niedawna zajmujący się dziedziną dotkniętą kryzysem, a przez to mniej przywiązani niż większość ich kolegów po fachu do wizji świata i reguł, jakie narzucał stary paradygmat.

KuHN, Struktura rewolucji..., s. 251.

${ }^{83}$ Por. np. Michael J. BeHE, „Współczesna hipoteza inteligentnego projektu. Łamanie reguł”, przeł. Dariusz Sagan, Na Poczatku... 2004, nr 7-8 (183-184), s. 244 [244-266], https://tiny.pl/g2s ml (24.11.2018); wypowiedź Williama A. Dembskiego w: Devon WiLliams, „Friday Five: William A. Dembski”, CitizenLink.com 14 December 2007, https://tiny.pl/g3h6z (24.11.2018); SAGAN, „Problem religijnego charakteru...”, s. 62.

${ }^{84}$ Por. Delfino, „Naturalizm metodologiczny...”, s. 155. Por. też wypowiedź Kazimierza Jodkowskiego w: Bartosz Borczyk, Adam Chmielewski, Andrzej Elżanowski, Kazimierz JodkowSKI, Damian Leszczyński, Jerzy Lukierski, Łukasz Nysler i Bogusław PawŁowski, „Dyskusja”, w: Damian Leszczyński (red.), Ewolucja. Filozofia. Religia, Lectiones \& Acroases Philosophicae 2010, vol. 3, s. 158 [155-172], https://tiny.pl/xh8gj (24.11.2018); PLANTingA, „Naturalizm metodologiczny...”, s. 90; Paul Davies, „Fizyka i umysł Boga. Przemówienie na uroczystości wręczenia Nagrody Templetona", przeł. Joanna Popek, Filozoficzne Aspekty Genezy 2011, t. 8, s. 19 [7-21], https://tiny.pl/xhnlk (22.03.2017).

${ }^{85}$ Krause, „Filozoficzne aspekty...”, s. 177-178. (Przywoływany autor, referując tę tezę, powołuje się na tekst Jacka KrebSA, „The New Science in Kansas Schools Position Paper by Jack Krebs, Kansas Citizens For Science, Science Standards in Kansas: The Real Issues”, który zamieszczony był na stronie Kansas Citizens for Science, http://www.kcfs.org. W chwili obecnej 
Decyzje te uzasadniane są na wiele sposobów. ${ }^{86}$ Trudno jednak zgodzić się z tezą, w myśl której fakty i logika są jedynymi czynnikami, które wpływają na treść decyzji metodologicznych. ${ }^{87}$

Omawiany argument wspierają na przykład takie uzasadnienia. Zgodnie z pierwszym z nich, które brzmi tak, jakby było wypowiedziane przez metodologicznego anarchistę,

jeśli przyjmiemy hipotezę, że rozwój ludzkiej myśli dziś się nie zakończył, to nie ma sensu dogmatycznie absolutyzować obecnej [naturalistycznej] definicji naukowości, gdyż nie wiadomo, co będzie jutro. ${ }^{88}$

Drugie z nich podkreśla, znany od dawna, podstawowy warunek efektywnego uprawiania nauki:

Nauka ma przed sobą świetlaną przyszłość pod warunkiem, że naukowcy będą mieli swobodę myślenia, w ramach wybranych przez siebie światopoglądów, a przy tym zachowają wysoką jakość swojej pracy. ${ }^{89}$

Swoboda uczonego, na co wielokrotnie zwracano uwagę, nie powinna być krępowana:

W nauce nie ma jednej tylko metody dochodzenia do wiedzy! Musimy wypróbowy-

(24.11.2018) tekst Krebsa jest niedostępny w Internecie.) Por. też Harry Lee PoE i Chelsea Rose Мүтүк, „Od metody naukowej do naturalizmu metodologicznego. Ewolucja idei”, przeł. Bartosz Błaszczak, Gerard Dmuch, Ewa Komorowska, Iwona Kumiszcze, Izabela Obłaczyńska, Katarzyna Piłka, Radosław Plato, Marika Poprawska, Dariusz Sagan, Karolina Stencel, Katarzyna Szot i Piotr Wróblewski, Filozoficzne Aspekty Genezy 2011, t. 8, s. 138 [137-151], https://tiny.pl/xh8gd (24.11.2018). O'Connor, „Nauka przed sądem...”, s. 102; Plantinga, „Naturalizm metodologiczny..."s. 92.

${ }^{86} \mathrm{~W}$ sprawie decyzji dotyczących naturalizmu metodologicznego por. np. KILIAN, „Argumenty na rzecz naturalizmu...”, s. 11-50.

${ }^{87}$ Por. np. Feyerabend, „Problems of Empiricism...”, s. 227-228; JodKowski, „Z jakim relatywizmem...", s. 123-146.

${ }^{88}$ Wypowiedź Damiana Leszczyńskiego w: Borczyk, Chmielewski, Elżanowski, Jodkowski, LeszczyŃski, Lukierski, Nysler, PawŁowski, „Dyskusja...”, s. 158. Por. też Patrick McDonald and Nivaldo J. Tro, „In Defense of Methodological Naturalism”, Christian Scholar's Review 2009, vol. 38, no. 2, s. 203 [201-229], https://tiny.pl/thtq7 (24.11.2018).

${ }^{89}$ BRAND, „Naturalizm i jego rola...”, s. 60. 
wać różne rzeczy, traktować je już to źle, już to dobrze, i zdobywać się wobec nich kolejno na sprawiedliwość i chłód. Ten rozmawia z rzeczami jak policjant, ów jak spowiednik, ktoś trzeci jak wędrowiec i człowiek ciekawy świata. ${ }^{90}$

Ułożyć taką receptę albo taką ogólną regułę, która by się nadawała dla wszystkich wypadków, jest niedorzecznością. Trzeba mieć własną głowę na karku, aby umieć się zorientować w każdym poszczególnym wypadku. ${ }^{91}$

Uczony staje w obliczu złożonej sytuacji. Zatem, aby wyciągnąć z niej jakieś korzyści, nie może używać prostej reguły, musi być oportunistą. ${ }^{92}$

Gdy prowadzisz badania, nie możesz być związany żadną regułą, nawet regułą niesprzeczności. Musisz być całkowicie wolny. ${ }^{93}$

Jest mi obojętne, jakich metod używa filozof (lub ktokolwiek inny), dopóki bada interesujące zagadnienie i dopóki rzeczywiście stara się je rozwiązać. ${ }^{94}$

Powtórzmy raz jeszcze, nie ma najmniejszego znaczenia to, jakich metod używamy dla rozwiązywania $[\ldots]$ problemów. ${ }^{95}$

Taka swoboda myślenia ma jednak swoje granice. Wyznacza je, jak zauważono, powszechnie przyjmowany EUO. Presja tego EUO może zneutralizować

${ }^{90}$ Fryderyk NiETzSCHE, Jutrzenka. Myśli o przesądach moralnych, przeł. Leon Marian Kalinowski, Wydawnictwo Zielona Sowa, Kraków 2006, §432, „Badacze i eksperymentatorzy”, s. 207.

${ }^{91}$ Włodzimierz Iljicz LenIN, „Dziecięca choroba «lewicowości» w komunizmie”, w: Włodzimierz Iljicz LenIN, Dziela. Tom 31, przekład (anonimowy) z czwartego wydania rosyjskiego przygotowanego przez Instytut Marksa-Engelsa-Lenina przy KC WKP(b), Książka i Wiedza, Warszawa 1955 , s. 54 [5-106].

Lenin zaleceniem tym pouczał komunistów. Zauważono jednak, że doskonale nadaje się ono do charakterystyki skutecznego uprawiania nauki (por. FeYerabend, „Against Method...”, s. 105 przyp. 38).

${ }^{92}$ Wypowiedź Alberta Einsteina przytaczam za Feyerabendem w: Renato Parascandalo and Vittorio Hösle, „Three Interviews with Paul K. Feyerabend”, Teleos. A Quarterly Journal of Critical Thought 1995, no. 102, s. 117 [115-148].

${ }^{93}$ Wypowiedź Nielsa Bohra przytaczam za Feyerabendem w: Joachim Jung, „Paul K. Feyerabend: Last Interview", w: John Preston, Gonzalo MunÉvar, and David Lamb (eds.), The Worst Enemy of Science?: Essays in Memory of Paul Feyerabend, Oxford University Press, New York, Oxford 2000, s. 162 [159-168].

${ }^{94}$ Karl R. Popper, Logika odkrycia naukowego, przeł. Urszula Niklas, Państwowe Wydawnictwo Naukowe, Warszawa 1977, s. 22.

${ }^{95}$ Popper, „Natura problemów filozoficznych...”, s. 130. 
nie tylko dowolną trudność teorii, która ten EUO akceptuje. ${ }^{96} \mathrm{Z}$ tego, że współczesna nauka uprawiana jest $\mathrm{w}$ ramach naturalistycznego EUO, łatwo przechodzi się do tezy, że odmienne, dopuszczające nadnaturalizm lub artyficjalizm, EUO mają charakter pseudonaukowy. ${ }^{97}$

5.2. Naturalizm metodologiczny - w myśl innego argumentu — jest jedynie indukcyjnym uogólnieniem — efektem 300-400 lat naukowej praktyki: ${ }^{98}$

Argumenty indukcyjne jednakowoż nie dowodzą swych wniosków w sposób pewny; dlatego nie jest to wystarczający powód, by uznać je za konieczny warunek działalności naukowej. ${ }^{99}$

Naturalizm metodologiczny w pełni funkcjonuje wskutek narzucenia go na naukę przez Darwina dopiero od roku 1859 i jest niczym innym niż małym zbiorem decyzji metodologicznych. Niektórzy zwolennicy tego podejścia uznają go też za nieredukowalny składnik skutecznego uprawiania nauki. ${ }^{100}$ To wszyst-

\footnotetext{
${ }^{96}$ Por. Kilian, „Argumenty na rzecz naturalizmu...”, s. 49-50.

${ }^{97}$ Por. Kazimierz Jodkowski, „Metafizyczne opowieści nauki jako fundament pluralizmu naukowego", w: Phillip E. Johnson, Wielka metafizyczna opowieść nauki (z posłowiem Kazimierza Jodkowskiego), przeł. Piotr Bylica, Archiwum Na Poczatku..., z. 13, Polskie Towarzystwo Kreacjonistyczne, Warszawa 2003, s. 75-77, 80-81 [74-85], https://tiny.pl/q3m5p (24.11.2018); Kazimierz JoDKowski, „Epistemiczny układ odniesienia teorii inteligentnego projektu”, Filozofia Nauki 2006, nr 1 (53), s. 95-97 [95-105], https://tiny.pl/q3m5n (24.12.2018); Kazimierz JodkowSKI, „Dlaczego kreacjonizm jest pseudonauką?”, w: Józef ZoN (red.), Pogranicza nauki. Protonauka - paranauka - pseudonauka, Wydawnictwo KUL, Lublin 2009, s. 323 [317-323], https ://tiny.pl/q3m5b (24.12.2018); JoDKowskI, „Zasadnicza nierozstrzygalność...”, s. 217-218, 221; Zenon E. Roskal, „Eksperyment MacDougalla w epistemicznym układzie odniesienia naturalizmu", w: Bylica, Kilian, Piotrowski i Sagan (red.), Filozofia - nauka - religia..., s. 166 przyp. 6, 172 [165-172], https://tiny.pl/g28sj (24.12.2018); wypowiedź Dariusza Sagana w: Piotr ByLICA, Małgorzata Gazda, Kazimierz Jodkowski, Krzysztof J. KiLIAN i Dariusz Sagan, „Dyskusja nad artykułem Adama Trybusa, «Program badawczy SETI a teoria inteligentnego projektu»», Filozoficzne Aspekty Genezy 2016, t. 13, s. 232-233 [211-242], https://tiny.pl/g8nvh (24.12.2018); KILIAN, „Argumenty na rzecz naturalizmu...”, s. 14-41.

${ }^{98}$ Por. Niall SHAnks, God, the Devil, and Darwin: A Critique of Intelligent Design Theory, Oxford University Press, New York 2004, s. 141.

${ }^{99}$ Delfino, „Zastapić metodologiczny naturalizm...”, s. 3.

${ }^{100}$ Por. np. Arthur N. Strahler, Understanding Science: An Introduction to Concepts and Issues, Prometheus Books, Buffalo, New York 1992, s. 3; Eugenie C. Scotт, „Darwin Prosecuted: Review of Johnson's Darwin on Trial", Creation/Evolution Journal 1993, vol. 13, no. 2, s. 43 [36-47], https://tiny.pl/g28vq (24.11.2018); Niles EldREDGe, The Triumph of Evolution and the
} 
ko nie pozwala jednak na ocenianie go w takich kategoriach jak w powyższym argumencie. Gdy mówi się o decyzjach, czyli pewnego rodzaju umowach, to ocenia się je nie w kategoriach aletycznych (prawdziwa/pewna/prawdopodobna - błędna/niepewna/nieprawdopodobna), ale w kategoriach pragmatycznych (skuteczna - nieskuteczna). Przyjmowane w nauce decyzje nie są ani pewne, ani niepewne. Są one, co najwyżej, skuteczne albo nieskuteczne. Wygłaszając taką tezę, pamiętać należy o ograniczonym zasięgu jej stosowalności. Niejednokrotnie miarą skuteczności jakiegoś rozwiązania jest perspektywa teoretyczna, w jakiej ono funkcjonuje. ${ }^{101}$

\section{Naturalizm jest regulą arbitralną i szkodliwą}

\subsection{W myśl jednego z argumentów, wspierających powyższą tezę,}

Nauka nie jest jaką́s grą, w której stosuje się arbitralne reguły decydujące o tym, jakie wyjaśnienia są dozwolone. Jest ona raczej próbą wysuwania prawdziwych twierdzeń o fizycznej rzeczywistości. ${ }^{102}$

Przyjmowany cel nauki, na co warto w tym miejscu zwrócić uwagę, jest pochodną akceptowanego wprzódy modelu wiedzy. Tych ostatnich da się wyróżnić co najmniej trzy. A zatem istnieją też co najmniej trzy cele stawiane nauce.

Zgodnie z pierwszym podejściem do wiedzy motywem ludzkich działań poznawczych jest ciekawość (samooświecenie):

Failure of Creationism, W.H. Freeman and Company, New York 2001, s. 137.

${ }^{101}$ Por. np. William B. Provine, „Projekt? Tak! Ale czy inteligentny?”, przeł. Sławomir Piechaczek, Filozoficzne Aspekty Genezy 2005/2006, t. 2/3, s. 233 [217-237], https://tiny.pl/xh8rs (24.11.2018); H. Allen OrR, „Ponownie darwinizm kontra inteligentny projekt”, przel. Dariusz Sagan, Filozoficzne Aspekty Genezy 2004, t. 1, s. 41 [33-48], https://tiny.pl/gzlkt (24.11.2018); Kazimierz JoDKowski, ,Eskapizm teologii i filozofii katolickiej w sprawie «nauka a religia»”, $N a$ Początku... 2005, nr 7-8 (196-197), s. 273-284 [261-284], https://tiny.pl/gztl8 (24.11.2018); Kazimierz Jodkowski, „Filozofia przyrody a nauki przyrodnicze”, Colloquia Communia 2007, nr 1-2 (82-83), s. 21-22 [15-22].

${ }^{102}$ Michael J. Bene, „Precyzyjny projekt: powstawanie biologicznych mechanizmów molekularnych”, przeł. Dariusz Sagan, Na Poczatku... 2004, nr 5-6 (181-182), s. 182 [163-183], https://ti ny.pl/glntc (24.11.2018). Por. też Kathryn Applegate, „A Defense of Methodological Naturalism”, Perspectives on Science and Christian Faith 2013, vol. 65, no. 1, s. 40 [37-45], https://tiny.pl/xh8 $\operatorname{tg}(24.11 .2018)$. 
Wszystkim ludziom wrodzone jest pragnienie poznania,

twierdził Arystoteles. ${ }^{103}$ Nastawienie takie nazwano, pozostając w zgodzie $\mathrm{z}$ etymologią słowa $\theta \varepsilon \omega \rho i \alpha$ (contemplatio), „kontemplatywnym modelem wiedzy” ${ }^{104}$ lub „modelem teoretycznym”. ${ }^{105}$ Człowiek chce po prostu wiedzieć, jak jest, celem jego działań jest zatem sama prawda.

Drugie podejście do wiedzy ma charakter praktyczny i zaowocowało dwoma nastawieniami, które łącznie można nazwać modelem korekcyjnym. Ich wspólnym celem jest poprawa warunków życia. Jeden z nich, konkwistadorski, umożliwić miał panowanie nad przyrodą, drugi, performancyjny, przeżycie we wrogim środowisku. Żaden z nich nie wyklucza ciekawości. Trudno zaprzeczyć tezie, że ciekawość jest motywem popychającym ludzi ku prowadzonym przez nich działaniom. Zmianom ulega tu hierarchia wartości. Dążenie do poznania nie jest wyłącznie dążeniem do prawdy.

Zgodnie z modelem konkwistadorskim, którego najbardziej znanym przedstawicielem jest Francis Bacon,

prawdziwy[m] zaś i właściwy[m] cel[em] nauk — [...] [jest] nic innego jak wyposażenie życia ludzkiego w nowe wynalazki i środki. ${ }^{106}$

\footnotetext{
${ }^{103}$ Arystoteles, Metafizyka, przeł. Tadeusz A. Żeleźnik, Redakcja Wydawnictw KUL, Lublin 1986, A980 a 1.

${ }^{104}$ Kazimierz JoDKOwsKI, „Kontemplatywny vs. performancyjny model wiedzy a Feyerabendowska krytyka nauki (miejsce nauki w hierarchii wartości różnych tradycji i form życia)", Studia Filozoficzne 1989, nr 10 (287), s. 101 [99-113].

${ }^{105}$ Andrzej L. Zachariasz, Poznanie teoretyczne. Jego konstytucja i status, Wydawnictwo UMCS, Lublin 1990, s. 32.

${ }^{106}$ Francis BACON, Novum Organum, przeł. Jan Wikarjak, Państwowe Wydawnictwo Naukowe, Warszawa 1955, ks. I, aforyzm LXXXI. Prawda była dla Bacona również ważnym celem, choć podporządkowanym panowaniu nad przyrodą:

w przyrodzie dzieła praktyczne nie tylko są dobrodziejstwem dla życia, lecz również są gwarantem prawdy. [...] Prawdę bowiem bardziej przez świadectwo praktyki niż przez argumentację, a nawet niż przez zmysły, można wydobyć na światło dzienne i uzasadnić.

Francis Bacon, Cogitata et visa (cyt. za: Kazimierz Ajdukiewicz, „Franciszek Bacon z Werulamu — Dzieło i życie", w: BACon, Novum Organum..., s. xv [vii-xciv].
} 
Zamierzenie angielskiego filozofa określane jest niekiedy Agrippowskim terminem „magia naturalna”. ${ }^{107}$ To, co magia robić miała za pomocą zaklęć znaleźć środki opanowania przyrody — on chciał robić, wykorzystując dostępną mu wiedzę. Nauka dokonać miała radykalnej zmiany warunków życia człowieka, dać mu wolność i niezależność od rozmaitych czynników zewnętrznych.

Nazwa ,performancyjny model wiedzy” i podstawowe idee wywodzą się od Gonzalo Munévara. Wiedza traktowana jest tu ewolucyjnie, jako „kły i pazury” gatunku ludzkiego, umożliwiające mu przetrwanie:

Model performancyjny kładzie nacisk na „radzenie sobie” we Wszechświecie, czyli na takie zachowania, które okazują się najbardziej właściwe na dłuższą metę. ${ }^{108}$

W ramach tego podejścia dana teoria naukowa uznana zostaje za lepszą od swej rywalki nie wtedy, gdy ta pierwsza okazuje się bliższa prawdy. Teoria jest lepsza wtedy, gdy za jej pomocą lepiej sobie radzimy z nowymi lub zmieniającymi się środowiskami. ${ }^{109} \mathrm{O}$ wartościowości wiedzy nie rozstrzyga zatem jej wartość aletyczna, lecz wartość przetrwania, jaką umożliwiają formułowane teorie. ${ }^{110}$

Autor omawianego teraz argumentu (6.1) opowiedział się za jednym z modeli wiedzy. Wybór ten (podobnie jak wybór dwóch innych) nie pozwala jednak na akceptację pierwszej części tego argumentu (nauka nie jest grą, w której stosuje się arbitralne reguły), która jest ponadto zdaniem fałszywym. Bez względu na to, jakiego modelu wiedzy jest się zwolennikiem, nie da się odeprzeć tezy, w myśl której występowanie arbitralnych reguł uprawiania nauki jest integralnym składnikiem poznania naukowego.

\footnotetext{
${ }^{107}$ Por. Wojciech SADY, Spór o racjonalność naukową. Od Poincarégo do Laudana, Monografie FNP, Wrocław 2000, s. 12.

${ }^{108}$ Gonzalo Munévar, Radical Knowledge: A Philosophical Inquiry into the Nature and Limits of Science, Hacket Publishing Company, Indianapolis 1981, s. 56.

${ }^{109}$ Por. JoDKowski, „Kontemplatywny vs. Performancyjny...”, s. 102.

${ }^{110}$ Por. Kazimierz Jodkowski, „Radykalna epistemologia”, Studia Filozoficzne 1984, nr 1112, s. 181 [179-187]; Radosław Plato, „Relatywizm ewolucyjny w ujęciu Gonzalo Munévara. Zarys stanowiska filozoficznego", w: Bylica, Kilian, Piotrowski i Sagan (red.), Filozofia — nauka — religia..., s. 257 [239-260], https://tiny.pl/thtxv (24.11.2018).
} 
O tym, że w nauce stosuje się arbitralne reguły, które mówią, jakie wyjaśnienia są dozwolone (lub zabronione), wiadomo od dawna. Rolę decyzji metodologicznych uwypuklali filozofowie nauki wszelkich orientacji, od konwencjonalizmu, przez logiczny empiryzm i krytyczny racjonalizm, po uhistorycznioną filozofię nauki. Mówili o tym na przykład Poincaré, Duhem, Lakatos czy Kuhn.

Poincaré zauważył, że pewna część teorii naukowej, nazywana przez niego zasadami (na przykład trzy prawa dynamiki i prawo grawitacji w teorii Newtona), staje się na mocy decyzji uczonych nieobalalna:

Gdy pewne prawo zostało dostatecznie stwierdzone przez doświadczenie, możemy obrać względem niego dwojakie stanowisko: albo pozostawić je w mieszaninie, a wówczas będzie ono podlegało ustawicznej rewizji, która koniec końcem okaże niewątpliwie, iż prawo to jest tylko przybliżone; albo też wynieść je do godności zasady, przyjmując umowy takie, iżby twierdzenie było z pewnością prawdziwe. ${ }^{111}$

Ideę tę później rozwinął Lakatos, pisząc o twardym rdzeniu naukowego programu badawczego. Rdzeń ten tworzą podstawowe prawa danego programu badawczego, które na mocy metodologicznej decyzji uznawane są za nieobalalne. ${ }^{112}$ Węgierski filozof przekonywał, że należy utrzymywać twardy rdzeń naukowego programu badawczego tak długo, jak połączona z nim heurystyka pozytywna wytwarza postępowe przesunięcie problemowe. ${ }^{113}$

Duhem zauważył to, co Kuhn mocno akcentował i rozwinął sześćdziesiąt lat później, że to określona wspólnota uczonych decyduje, czy zaproponowane przez indywidualnego uczonego rozwiązania mogą się stać składnikami powszechnie przyjmowanych rozwiązań naukowych. ${ }^{114}$ Duhem twierdził też, że

\footnotetext{
${ }^{111}$ Henri PoIncaré, Wartość nauki, przeł. Ludwik Silberstein, Nakład Jakóba Mortkowicza, G. Centnerszwer i Ska, Księgarnia H. Altenberga, Warszawa - Lwów 1908, s. 154, https://tiny. $\mathrm{pl} /$ thtmq (24.11.2018).

${ }^{112}$ Por. Imre LaKatos, „Falsyfikacja a metodologia naukowych programów badawczych”, w: Imre LaKatos, Pisma z filozofii nauk empirycznych, przeł. Wojciech Sady, Biblioteka Wspótczesnych Filozofów, Wydawnictwo Naukowe PWN, Warszawa 1995, s. 74 [3-169].

${ }^{113}$ Por. Imre LaKatos, „Criticism and the Methodology of Scientific Research Programmes”, Proceedings of the Aristotelian Society. New Series 1968-1969, vol. 69, s. 179 [149-186].

${ }^{114}$ Por. Pierre Duнem, „La théorie physique - son objet, et sa structure”, przeł. Monika Sakowska, w: Krzysztof Szlachсic, Filozofia nauk empirycznych Pierre'a Duhema, Wydawnictwo Uniwersytetu Wrocławskiego, Wrocław 2011, s. W79-W80 [W36-W95]; Krzysztof J. KiLIAN, „Fi-
} 
młody uczony, aby opanować sposób posługiwania się teorią, przechodzi określony trening w trakcie swojej edukacji. Przez naśladowanie starszych, bardziej doświadczonych uczonych, uczy się konkretnych zastosowań teorii - wybierania powszechnie uznawanych rozwiązań, widzenia świata przez pryzmat danej teorii. ${ }^{115}$ Mówiąc językiem Kuhna, młody uczony zapoznaje się z „regułami gry" naukowej, które mówią adeptowi niemal wszystko, co na temat uprawiania nauki wiedzieć powinien. ${ }^{116}$ (Takich składników teorii naukowych — reguł gry naukowej, których uczeni w trakcie normalnego uprawiania nauki nie podważają, jest więcej niż odnaleźć można u Poincarégo i Duhema.) Te reguły to zbiory założeń - aksjologicznych, instrumentalnych, pojęciowych, metodologicznych i ontologicznych, które umożliwiają uprawianie nauki w ramach danej tradycji badań naukowych, gdyż mówią, jak należy i jak nie należy postępować w trakcie badań naukowych. ${ }^{117}$

6.2. Naturalizm metodologiczny, przekonuje kolejny argument,

przekształcił $[\ldots]$ rozsądną przesłankę metodologiczną w dogmatyczne stwierdzenie na temat natury wszechświata, ${ }^{118}$

a dogmaty nie są częścią nauki. ${ }^{119}$

Czy dogmatyzm naukowy należy wartościować pozytywnie (bo na przykład zapobiega to pochopnej akceptacji słabo uzasadnionych poglądów ${ }^{120}$ ), czy też należy go wartościować negatywnie (gdyż przykładowo uniemożliwia on do-

lozoficzne podstawy nauki”, Sofia. Pismo Filozofów Krajów Stowiańskich 2015, vol. 15, s. 78-79 [69-85], https://tiny.pl/gz61z (24.11.2018).

${ }^{115}$ Por. Duhem, „La théorie physique...”, s. W87-W88.

${ }^{116}$ Por. Kunn, Struktura rewolucji..., s. 81.

${ }^{117}$ Por. Thomas S. Kunn, „The Function of Dogma in Scientific Research”, w: Alistair Cameron Crombie (ed.), Scientific Change: Historical Studies in the Intellectual, Social and Technical Conditions for Scientific Discovery and Technical Invention, from Antiquity to The Present, Symposium on the History of Science, University of Oxford 9-15 July 1961, Heinemann, London 1963, s. 357 [347-369].

${ }^{118}$ Phillip E. Johnson, „Evolution as Dogma: The Establishment of Naturalism”, First Things October 1990, https://tiny.pl/thtm9 (24.11.2018). Por. też Johnson, „Co to jest...”, s. 108; Delfino, „Zastąpić metodologiczny naturalizm...”, s. 2; Delfino, „Naturalizm metodologiczny...”, s. 142.

${ }^{119}$ Delfino, „Zastąpić metodologiczny naturalizm...”, s. 2; Delfino, „Naturalizm metodologiczny...", s. 142 . 
strzeganie rozwiązań alternatywnych ${ }^{121}$ ), to kwestia, która wciąż budzi wiele kontrowersji. ${ }^{122}$ Omawiany argument nie wpisuje się jednak w tę dyskusję. Jest jedynie mało wiarygodnym, pozbawionym odniesienia do historii filozofii nauki, stwierdzeniem dotyczącym mechanizmów funkcjonowania nauki:

Najprawdopodobniej nikt z nas nie wierzy, że w swojej codziennej praktyce naukowcy realizują ten ideał [...] [w myśl którego] [...] naukowiec jako bezstronny poszukiwacz prawdy $[\ldots]$ jest $[\ldots]$ człowiekiem, który odrzuca uprzedzenia u progu swego laboratorium i zbiera oraz bada nagie i obiektywne fakty. Jest on lojalny w stosunku do tych faktów i tylko w stosunku do nich. ${ }^{123}$

Na rzecz „dogmatyzmu dojrzałej nauki”, ${ }^{124}$ czyli tezy, zgodnie z którą nauka nie może rozwijać się bez sporej dawki dogmatyzmu, przekonywano za pomocą następujących argumentów.

Efektem naukowej edukacji jest głębokie zaangażowanie w konkretny sposób postrzegania świata. Zaangażowanie to przejawia się tym, że ten sposób widzenia narzuca automatycznie określony sposób uprawiania nauki - akceptacją takich, a nie innych reguł gry naukowej. (Zaangażowanie takie, raz na jakiś

\footnotetext{
${ }^{120}$ Por. np. Michael Polanyi, „The Republic of Science: Its Political and Economic Theory”, Minerva 2000, vol. 38, s. 8-9 [1-32], https://tiny.pl/thtm3 (24.11.2018).

${ }^{121}$ Por. np. Fred Hoyle, Matematyka ewolucji, przeł. Robert Piotrowski, Wydawnictwo MEGAS, Warszawa 2003, s. 16-17.

${ }^{122}$ Por. np. Henry H. Bauer, Dogmatism in Science and Medicine: How Dominant Theories Monopolize Research and Stifle the Search for Truth, McFarland \& Company, Jefferson 2012, s. $5-12$.

Istnieje też pogląd, w myśl którego nauka de facto nie jest dogmatyczna:

Nauka natomiast z zasady nie przyjmuje dogmatów, a tak zwane paradygmaty nauki to tylko typowy w jakimś okresie sposób stawiania i rozstrzygania problemów badawczych, który jednakże może ulec zmianie w rezultacie rozwoju nauki.

Jerzy LuKIERSKI, „Nauka i religia - czy można pogodzić”, s. 2 [1-5], https://tiny.pl/gzpd2 (24.11.2018). Pogląd ten jest błędny. Dopóki jednak — o czym wspominano przy okazji analiz poprzedniego (6.1) argumentu i będzie jeszcze mowa w trakcie omówienia tego (6.2) argumentu - ten typowy sposób stawiania i rozstrzygania problemów nie ulegnie zmianom, to inne takie sposoby uznawane są za nienaukowe.

${ }^{123}$ Kunn, ,The Function of Dogma...”, s. 347.

${ }^{124}$ Por. Kunn, „The Function of Dogma...”, s. 349.
} 
czas, zastępowane jest innym zaangażowaniem. Nigdy jednak nie jest tak, że naukę uprawia się bez takiego zaangażowania.) W następstwie powszechnej akceptacji reguł gry naukowej tworzy się wspólnota profesjonalistów. Wspólne jej reguły i ich przestrzeganie gwarantują owocne badania naukowe — wskazują na istotne problemy oraz na sposoby ich rozwiązywania.

Akceptacja konkretnych reguł gry tożsama jest z przyjęciem przekonania o istnieniu mocnego, bo gwarantującego istnienie rozwiązania dla każdego istotnego problemu, fundamentu uprawiania nauki. W następstwie tego wiele konkretnych i początkowo niezrozumiałych problemów znajduje rozwiązanie. Nieoczekiwane fakty również łatwiej wychodzą na jaw wtedy, gdy prowadzone są szczegółowe badania, niż wtedy, gdy prowadzi się spory w sprawach zasadniczych. ${ }^{125}$

\section{Naturalizm metodologiczny jest podejściem irracjonalnym}

Tez ta wspierana jest następującym argumentem:

ponieważ dostarczenie naturalistycznych wyjaśnień wszystkich zjawisk jest raczej nieosiągalne, więc wierność koncepcji nauki podlegającej temu ograniczeniu jest irracjonalna. ${ }^{126}$

Pomimo tego, że na przykład kuhnowskie spojrzenie na naukę potwierdza pierwszą część tego argumentu, ${ }^{127}$ to argument jest nietrafny, bo prowadzi do

${ }^{125}$ Por. KuHn, „The Function of Dogma...”, s. 349-350, 357, 364; KuHN, Struktura rewolucji..., s. 76-79; Kazimierz JoDKOWSKI, Wspólnoty uczonych, paradygmaty i rewolucje naukowe, Realizm. Racjonalność. Relatywizm, t. 22, Wydawnictwo UMCS, Lublin 1990, s. 162-163; Krzysztof JANKOwSKI, „Ewolucja pojęcia paradygmatu w Strukturze rewolucji naukowych Thomasa S. Kuhna”, Sofia. Pismo Filozofów Krajów Stowiańskich 2016, vol. 16, s. 222-224 [211228], https://tiny.pl/g3w61 (24.11.2018).

${ }^{126}$ O’Connor, „Nauka przed sądem...”, s. 108 [wyróżnienie dodane]. Tezę tę przypisuje O'Connor autorom artykułów zebranych w książce The Creation Hypothesis pod redakcją J.P. Morelanda (por. Moreland (ed.), The Creation Hypothesis...) i opatruje krytycznymi komentarzami (s. 109-111). Por. też Larson, „O argumencie z Boga...”, s. 201. Ten ostatni autor broni tej tezy.

${ }^{127}$ Por. też np. Phillip G. Frank, „The Variety of Reasons for the Acceptance of Scientific Theories", w: Phillip G. Frank, The Validation of Scientific Theories, The Beacon Press, Boston 1956, s. 3 [3-28]; LaKatos, ,Falsyfikacja a metodologia...”, s. 77. 
niemożliwych do zaakceptowania konsekwencji. Długofalowym efektem rutynowych badań w ramach nauki normalnej jest wzrost liczby anomalii. To ostatnie zaś jest jednym z czynników wpływających na rozpowszechnianie się przekonania o wadliwości danego paradygmatu. W następstwie tego dojść może do prób zastąpienia go innym paradygmatem. Jeśli jednak wyznacznikiem racjonalności działań uczonych miałoby być przekonanie, że i tak, w końcowym efekcie, dojdzie do takiej sytuacji, iż przyjęte ujęcie teoretyczne ugnie się pod nadmiarem anomalii, a w związku z tym nie należy obstawać przy tym ujęciu, to uczeni nigdy nie powinni przyjmować żadnego ujęcia teoretycznego. Oczywistą konsekwencją tego ostatniego byłaby niezdolność do prowadzenia jakichkolwiek badań naukowych, gdyż

to dzięki paradygmatowi społeczność uczonych zyskuje kryterium wyboru problemów, które - dopóki przyjmuje się ten paradygmat - można uznać za rozwiązalne 128

i z paradygmatów

wywodzą się metody, zakres problematyki i wzorce rozwiązań, jakie w danym okresie akceptuje każda dojrzała społeczność uczonych. ${ }^{129}$

\section{Naturalizm jest kiepską filozofią}

Tezę tę wspiera kilka argumentów. Zgodnie z jednym z nich:

8.1. Naturalizm jest tylko „filozoficzn[a] doktryn[a] ], ${ }^{130}$

nie bardziej ,naukową” (czyli empirycznie wspartą) niż każdy inny rodzaj wyznania, ${ }^{131}$

\footnotetext{
${ }^{128}$ KunN, Struktura rewolucji..., s. 76.

${ }^{129}$ KuHN, Struktura rewolucji..., s. 185.

${ }^{130}$ Johnson, „Co to jest...”, s. 103. Por. też Jodkowski, „Metafizyczne opowieści...”, s. 75-76; Kazimierz Jodkowski, „Twarde jądro ewolucjonizmu”, Roczniki Filozoficzne 2003, t. 51, z. 3, s. 78-79 [77-117], https://tiny.pl/q3m5j (24.11.2018).

${ }^{131}$ Johnson, „Evolution as Dogma...”. Por. też Robert T. Pennock, „Naturalism, Evidence and Creationism: The Case of Phillip Johnson”, Biology and Philosophy 1996, vol. 11, s. 544-548 [543-559], https://tiny.pl/thttp (24.11.2018).
} 
a nie, opierającym się na świadectwach empirycznych, poglądem naukowym. ${ }^{132}$

Zauważono, że tego typu argumentacja wprowadza fałszywe przekonanie, w myśl którego

ewolucjonizm jest kiepską teorią, może nawet teorią pseudonaukową, skoro musi podpierać się filozofią. ${ }^{133}$

Dawno temu dostrzeżono też kwestię jeszcze bardziej fundamentalną — $\mathrm{z}$ nauki nie da się wyrugować filozofii. ${ }^{134}$

Jeszcze jedną sprawą, o której warto w tym miejscu wspomnieć, jest to, że akceptacja lub odrzucenie naturalizmu jest decyzją metodologiczną. Tak jak każda inna decyzja metodologiczna, jego akceptacja nie może opierać się na świadectwach empirycznych, bo to tego rodzaju decyzja dopiero pozwala uznawać coś (lub nie uznawać) za świadectwo empiryczne.

8.2. Inny argument $\mathrm{z}$ tej grupy głosi, że naturalizm prowadzi do naukowego antyrealizmu, w którym, tak jak w idealizmie, „rzeczywistość musi zgadzać się z ideami” (w realizmie „,idee zgadzają się z rzeczywistością”), gdyż interpretacja świadectw empirycznych i konstrukcja teorii musi dopasować się do schematu naturalistycznego. ${ }^{135}$

W myśl klasycznego ujęcia naukowego realizmu teorie naukowe są prawdziwe lub fałszywe, a to, jaka jest dana teoria, zależy od struktury świata. Jeśli

\footnotetext{
${ }^{132}$ Por. Delfino, „Naturalizm metodologiczny...”, s. 142; Delfino, „Zastąpić metodologiczny naturalizm...”, s. 2; Robert T. PenNock, „Bóg w lukach wiedzy: argument z niewiedzy i ograniczenia naturalizmu metodologicznego", przeł. Dariusz Sagan, Filozoficzne Aspekty Genezy 2012, t. 9, s. 158 [155-185], https://tiny.pl/tht9b (25.11.2018); Elliott SoBER, „Teoria inteligentnego projektu a nadnaturalizm - o tezie, że projektantem może być Bóg lub istoty pozaziemskie”, przeł. Sławomir Piechaczek, Filozoficzne Aspekty Genezy 2007/2008, t. 6/7, s. 38 [21-39], https://tiny.pl /xhn85 (25.11.2018); Johnson, „Evolution as Dogma...”.

${ }^{133}$ JodKowski, „Metafizyczne opowieści nauki...”, s. 80. Por. też SAGAN, „Naturalizm metodologiczny - konieczny...”, s. 81; Keith B. Miller, „The Misguided Attack on Methodological Naturalism", w: Jill S. Schneiderman and Warren D. Allmon (eds.), For the Rock Record: Geologists on Intelligent Design, University of California Press, Berkeley - London 2009, s. 120 [117-140].

${ }^{134}$ Por. ENGELs, Dialektyka przyrody..., s. 244-245.

${ }^{135}$ Por. Delfino, „Zastąpić metodologiczny naturalizm...”, s. 5; Delfino, „Naturalizm metodologiczny...", s. 154-155.
} 
teoria jest prawdziwa, to jej terminy teoretyczne denotują realne przedmioty. Te ostatnie są przyczynowo odpowiedzialne za zachodzenie, potwierdzających tę teorię, obserwowanych zjawisk. Możemy posiadać uzasadnione przekonania co do prawdziwości lub fałszywości naszych teorii oraz istnienia przedmiotów teoretycznych. Celem nauki jest odkrywanie prawdy lub zbliżanie się do prawdy. Nauka ten cel realizuje. ${ }^{136}$

Autor powyższego argumentu najwyraźniej ma na myśli jakieś inne rozumienie naukowego realizmu. Zdaje się on stać na stanowisku, zgodnie z którym naukowy realizm wyklucza przekonanie o mocnym i umiarkowanym uteoretyzowaniu obserwacji, ${ }^{137}$ oraz jest podejściem zbliżonym do teorii odbicia. W myśl tej ostatniej obiektywna rzeczywistość

dana jest człowiekowi we wrażeniach, którą nasze wrażenia kopiują, fotografują, odzwierciedlają, a która istnieje niezależnie od nich. ${ }^{138}$

Teoria ta, jak utrzymują jej zwolennicy,

której źródłem jest wyłącznie doświadczenie, jest właśnie najbardziej — by tak rzec — postępowa i najbardziej naukowa, ponieważ wolna jest od wszelkich mitycznych i me-

\footnotetext{
${ }^{136}$ Por. William H. Newton-Smith, „The Underdetermination of Theory by Data”, Proceedings of the Aristotelian Society 1978, Supplement, vol. 52, s. 71-72 [71-91].

${ }^{137}$ Uteoretyzowanie obserwacji może być rozumiane na trzy sposoby. Stanowisko najłagodniejsze utrzymuje, że istnieją teoretycznie neutralne obserwacje. Uteoretyzowanie rozumiane jest tu jako zogniskowanie uwagi — różne teorie mogą akcentować odmienne obserwacje, każda teoria może wybierać istotne dla niej obserwacje i pomijać nieistotne. Stanowisko umiarkowane sprowadza się do przekonania, że w każdej obserwacji da się wyróżnić dwa elementy: teoretyczny i obserwacyjny. Podczas przechodzenia od teorii do teorii dochodzi do zmiany interpretacji faktów, a nie samych danych czy faktów. Stanowisko skrajne kładzie nacisk na to, że obserwacje są całkowicie zależne od teorii, że zmiana teorii powoduje zmianę widzenia świata (por. Kazi mierz Jodkowski, Teza o niewspółmierności w ujęciu Thomasa S. Kuhna i Paula K. Feyerabenda, Realizm. Racjonalność. Relatywizm, t. 1, Wydawnictwo UMCS, Lublin 1984, s. 16-17; JoDKOwSKI, Wspólnoty uczonych..., s. 179-180; Kazimierz JoDKоwSKI, „Obserwacja zmysłowa jako postrzeganie wirtualnej rzeczywistości”, w: Ewa KоснаN (red.), Rzeczywistość wirtualna. Światy przedstawione w nauce i sztuce, Rozprawy $i$ Studia, t. 522, Wydawnictwo Naukowe Uniwersytetu Szczecińskiego, Szczecin 2005, s. 121-122 [121-153]; James Bogen, „Experiment and Observation”, w: Peter Machamer and Michael Silberstein (eds.), The Blackwell Guide to the Philosophy of Science, Blackwell Publishers Ltd., Malden — Oxford 2002, s. 132 [128-148]).
}

${ }^{138}$ Lenin, Dzieła. Tom 14..., s. 145. 
tafizycznych przesądów. ${ }^{139}$

Teza, która — zgodnie z intencjami autora omawianego argumentu — określa naukowy realizm, mogłaby brzmieć tak: obiektywna rzeczywistość dana jest we wrażeniach, którą wrażenia odzwierciedlają, zaś usunięcie wszelkich przeszkód (metafizycznych przesądów) stojących na drodze podmiot-przedmiot umożliwi raz na zawsze dopasowanie się schematu poznawczego do rzeczywistości.

Dodanie do klasycznej charakterystyki naukowego realizmu tej tezy lub też charakteryzowanie tego realizmu jedynie za pomocą wspomnianej tezy wykluczy z obszaru naukowego realizmu również i dwa, kreacjonistyczne i artyficjalistyczne, antynaturalistyczne EUO. Bowiem i w ich ramach interpretacja świadectw empirycznych i konstrukcja teorii musi dopasować się do schematów kształtowanych przez ich twarde jądra. ${ }^{140}$

8.3. Zgodnie $\mathrm{z}$ następnym argumentem $\mathrm{z}$ tej grupy, naturalizm jest złą metafizyką, gdyż

nie uwalnia nauki od restrykcyjnych wyjaśnień metafizycznych, lecz [jedynie] wzmacnia status naturalizmu jako właściwego metafizycznego wyjaśnienia. [...] Podstawą metody naukowej nie jest oczywiście ani naturalizm, ani żadna inna metafizyka. U jej podstaw leży metafizyczny neutralizm. ${ }^{141}$

Autorzy argumentu nie zadali sobie trudu, by dokładnie wyjaśnić, czym jest dla nich metafizyczny neutralizm. Jedyny kontekst, pozwalający przypuszczać, czym dla nich jest wspomniana kategoria, brzmi tak:

Dopóki naukowcy są gotowi formułować hipotezy, opisywać sposób ich testowania, prezentować dane, wyjaśniać sposób ich analizy oraz płynące stąd wnioski, nie powinno mieć znaczenia, czy modlą się do Zeusa, Jahwe, Wróżki Zębuszki czy też do nikogo. Ich praca będzie mówić sama za siebie. ${ }^{142}$

\footnotetext{
${ }^{139}$ Abram DeBorin, „Krytyka empiriomonizmu Bogdanowa”, przeł. W. Jankowski, Samokształceniowe Koło Filozofii Marksistowskiej, Warszawa 2008, s. 3 [1-9], https://tiny.p1/gz6j3 (25.11.2018).

${ }^{140}$ Por. Kilian „Geneza idei...”, s. 144-168.

${ }^{141}$ Poе i Mүтүк, „Od metody...”, s. 150-151.

${ }^{142}$ Cornelia Dean, „Faith, Reason, God and Other Imponderables”, The New York Times 25
} 
Pozwala to domniemywać, że metafizyczny neutralizm jest tezą, która postuluje jakąś postać epoché, powstrzymywania się od wygłaszania przekonań na temat sposobu istnienia świata. ${ }^{143}$

W ramach podobnego ujęcia

zasada metodologicznej neutralności orzeka, iż naukowcy powinni po prostu szukać przyczyn bez zakładania a priori warunków, jakie ontologicznie one muszą spełnić. [...] Przez nie wyznaczanie jakichkolwiek warunków apriorycznych możemy podążać za faktami (świadectwami), gdziekolwiek nas zabiorą. [...] kiedy już badania doprowadzą do zgromadzenia dowodów, naukowiec może przychylić się ku naturalności bądź nadnaturalności przyczyny, zależnie od dowodów. ${ }^{144}$

Wbrew optymistycznym deklaracjom z przytaczanych przed chwilą wypowiedzi, ani praca uczonych nigdy nie będzie mówić sama za siebie, ani nie możemy swobodnie podążać za faktami. Epoché stoi w niezgodzie z tym, co faktycznie robią uczeni.

$\mathrm{W}$ ramach jednego z najobszerniejszych wyjaśnień mechanizmów zmiany naukowej twierdzi się, że uprawianie nauki polega na rozwijaniu konkretnego paradygmatu (macierzy dyscyplinarnej). Przyjęcie tej macierzy prowadzi uczonych do akceptacji określonych przekonań. Te ostatnie mówią o tym, z jakich składników zbudowany jest świat; jak składniki te odziaływują na siebie i na nasze zmysły; jakie pytania dotyczące tych składników należy zadawać oraz jakich technik należy używać w celu uzyskania pożądanych odpowiedzi. Mówi też o tym, jakie kryteria decydują o poprawności zastosowanych rozwiązań. ${ }^{145}$ Ze składników macierzy, której elementami są: wzorce, symboliczne uogólnienia, wartości naukowe i modele (ontologiczne i heurystyczne), szczególnie istotne w kontekście podejmowanego tu problemu są te ostatnie.

July 2006, https://tiny.pl/gsx76 (25.11.2018). Por. też Poe i Mүтүк, „Od metody...”, s. 151.

${ }^{143} \mathrm{~W}$ swej najbardziej znanej postaci epoché to oczywiście Husserlowska redukcja transcendentalna.

${ }^{144}$ Delfino, „Zastąpić metodologiczny naturalizm...”, s. 10-11.

${ }^{145}$ Por. KuHN, Struktura rewolucji..., s. 26, 29, 35, 55-56, 60; Wojciech SADY, „Kuhn kontra Fleck a Maxwellowska rewolucja w elektrodynamice”, Przeglad Filozoficzny - Nowa Seria 2010, nr 2, s. 105 [103-131]. 
W modelach znajdują swój wyraz częściowo podzielane przez członków wspólnoty uczonych przekonania dotyczące badanego przez nich wycinka świata oraz trafnych wyjaśnień lub rozwiązań problemów. ${ }^{146}$ Modele ontologiczne informują o tym, co istnieje ${ }^{147}$ (na przykład ,istnieje tylko materia w ruchu" ${ }^{148}$ ) i jak to, co istnieje, na siebie oddziałuje (na przykład „wszystkie postrzegalne zjawiska są rezultatem oddziaływań pozbawionych jakości atomów poruszających się w próżni”). ${ }^{149}$ Modele te wyrażają przekonania wspólnoty na temat ostatecznej struktury i mechanizmów funkcjonowania badanego przez wspólnotę fragmentu rzeczywistości. Nie muszą one być podzielane przez całą, zajmującą się konkretną dyscypliną, wspólnotę. Przykładowo astronomowie, zwolennicy teorii Ptolemeusza, nie byli zgodni w sprawie realnego istnienia epicykli i deferentów, zaś chemicy działający na początku dziewiętnastego wieku nie byli zgodni w sprawie istnienia atomów. Wynika z tego, że uczeni są słabiej przywiązani do modeli ontologicznych niż do pozostałych składników macierzy i, prowadząc rutynowe badania $w$ ramach nauki normalnej, mogą się od siebie różnić w poglądach na to, co istnieje (przyjmować różne modele ontologiczne). ${ }^{150}$

Nie powinno to jednak przesłaniać faktu, że uczeni zawsze jakiś model ontologiczny przyjmują i przemawiają przez ten model, a nie w jakikolwiek inny

\footnotetext{
${ }^{146}$ Por. Thomas S. Kunn, „Odpowiedź moim krytykom”, w: Thomas S. KuHn, Droga po Strukturze. Eseje filozoficzne z lat 1970-1993 i wywiad-rzeka z autorem słynnej „Struktury rewolucji naukowych", wyd. James Conant i John Haugeland, przeł. Stefan Amsterdamski, Wydawnictwo Sic!, Warszawa 2003, s. 156-157 [117-162].

${ }^{147}$ Por. KunN, Struktura rewolucji..., s. 83.

${ }^{148}$ Por. KunN, Struktura rewolucji..., s. 83.

${ }^{149}$ Por. Thomas S. Kuhn, „Postscriptum (1969)”, w: Kunn, Struktura rewolucji..., s. 318 [301-360].

${ }^{150}$ Sprawa ta, jak zauważono, świadczy o zasadniczym odejściu Kuhna od jednej z głównych tez Struktury (por. Kazimierz JoDKowsKI, „Pojęcie paradygmatu a wspólnotowy charakter nauki w ujęciu Thomasa S. Kuhna”, Annales Universitatis Mariae Curie-Skłodowska 1983, vol. 8, sec. I, s. 52 [41-56]; Krzysztof JANKOwSKI, „Paradygmat jako podstawa normalnego uprawiania nauki: nauki społeczne a przyrodoznawstwo. Ujęcie Thomasa Samuela Kuhna”, In Gremium. Studia nad Historia, Kultura i Polityka 2017, nr 11, s. 204 [193-231]). W eseju tym utrzymywał on, że w okresach nauki normalnej nie pojawiają się metafizyczne kontrowersje wewnątrz danej społeczności uczonych.
} 
sposób. ${ }^{151}$ Zmiany w przyjmowanej ontologii idą w parze ze zmianami w sposobie mówienia o rzeczywistości:

zmianom ontologii [...] często towarzyszy zmiana pojęć. Odkrycie, że niektóre przedmioty nie istnieją, może zmusić uczonego do ponownego opisania zdarzeń, procesów, obserwacji, które były traktowane jako ich manifestacje i dlatego opisywane były w terminach zakładających istnienie tych przedmiotów. [...] Gdy wadliwa ontologia jest wszechstronna, czyli gdy [...] jej elementy obecne są w każdym procesie i w każdej dziedzinie, ma miejsce ciekawe wydarzenie [...] każdy opis wewnątrz jej dziedziny musi zostać zmieniony i zastąpiony odmiennymi twierdzeniami. ${ }^{152}$

Podstawą metody naukowej zawsze jest jakaś metafizyka. Każda metodologia uwikłana jest w założenia kosmologiczne. Przykładowo „naiwny falsyfikacjonista zakłada, że nie ma bezmiaru anomalii. Konwencjonalista zakłada, że świat zbudowany jest w sposób prosty [...] itd." ${ }^{153}$

Efektem zmiany metafizyki jest zmiana metody naukowej:

Standardy, którymi się posługujemy, i reguły przez nas zalecane mają sens jedynie w świecie posiadającym pewną strukturę. Natomiast tracą zastosowanie lub stają się nieefektywne w dziedzinie, która nie wykazuje takiej struktury. Gdy usłyszano o odkryciach Kolumba, Magellana, Diaza, zdano sobie sprawę, że istnieją kontynenty, klimaty, rasy, których nie wymieniano w starożytnych opisach, i zaczęto domniemywać, iż mogą istnieć także nowe kontynenty wiedzy, że może istnieć jakaś „Ameryka Wiedzy”, tak samo jak istnieje nowy byt geograficzny zwany „Ameryką”. Próbowano więc ją odkryć, wyprawiając się poza granice zastanych idei. Tak oto wymóg zwiększania treści wiedzy uzyskał kluczowe znaczenie. Wyrósł on z pragnienia, aby coraz głębiej poznawać naturę, która wydała się nieskończenie bogata ilościowo i jakościowo. Wymóg ten nie ma sensu w skończonym świecie zbudowanym ze skończonego zestawu podstawowych jakości. ${ }^{154}$

Decyzja o epoché wcale nie jest zatem taką prostą sprawą, jak sugerują to

\footnotetext{
${ }^{151}$ Por. KuHn, „Odpowiedź...”, s. 149.

${ }^{152}$ Feyerabend, „Against Method...”, s. 81-82.

${ }^{153}$ Paul K. Feyerabend, „Krytyka naukowego rozumu”, przeł. Edmund Mokrzycki, w: Edmund MокRZYскі (red.), Racjonalność a styl myślenia, Wydawnictwo IFiS PAN, Warszawa 1992, s. 208 przyp. 51 [167-217].

${ }^{154}$ Feyerabend, Przeciw metodzie..., s. 234.
} 
autorzy omawianego tu argumentu. ${ }^{155} \mathrm{Za}$ taką, a nie inną metafizyką idzie taki, a nie inny sposób widzenia świata, a co za tym idzie - inny sposób porządkowania danych. ${ }^{156}$

\section{Naturalizm jest ujęciem przyjmowanym bezkrytycznie}

Na rzecz powyższej tezy argumentowano tak. Zdarza się, że wyjaśnienia naturalistyczne wraz z krytyką innego rodzaju wyjaśnień są efektem pochopnego przyswajania, przedstawianych przez autorytety $\mathrm{w}$ danej dziedzinie, błędnych argumentów. Ilustracją powyższego stwierdzenia jest sytuacja, która powstała w następstwie błędnej interpretacji wyników badań, ${ }^{157}$ przedstawionych w artykule analizującym proces krzepnięcia krwi. ${ }^{158}$ Takiej interpretacji dokonał wybitny biochemik zajmujący się białkami, Russell Doolittle. ${ }^{159}$ Problem nie polega na tym, czy Doolittle miał rację. ${ }^{160}$ Jego argumenty (wraz z literowym, drukarskim błędem w nazwie białka, jaki pojawił się w jego tekście) przytoczył następnie znany krytyk kreacjonizmu i teorii inteligentnego projektu, filozof Michael Ruse. Posłużyły one Ruse'owi do krytycznej oceny zagadnienia nieredukowalnej złożoności kaskady krzepnięcia krwi. Później zaś argumenty Doolittle’a przytoczył inny uczony, patolog Neil S. Greenspan oraz redaktor naczelny Scientific American, John Rennie. ${ }^{161}$ Greenspan na podstawie argumentów Doolittle'a twierdził, że zwolennicy teorii inteligentnego projektu nie rozumieją,

\footnotetext{
${ }^{155}$ Por. KILIAN, „Epistemiczne układy odniesienia a problem interteoretycznej niewspółmierności - część 2...”, s. 291-294.

${ }^{156}$ Por. Paul K. Feyerabend, „Wyjaśnianie, redukcja i empiryzm”, w: Feyerabend, Jak być dobrym empirystą..., s. 71 [62-151].

${ }^{157}$ Por. BeHE, „Nieredukowalna złożoność...”, s. 88-89.

${ }^{158}$ Por. T.H. Bugge, K.W. Kombrinck, M.J. Flick, C.C. Daugherty, M.J. Danton, and J.L. Degen, „Loss of Fibrinogen Rescues Mice from the Pleiotropic Effects of Plasminogen Deficiency”, Cell 1996, vol. 87, s. 709-719.

${ }^{159}$ Por. Russell F. Doolittle, „Subtelna równowaga”, przeł. Dariusz Sagan, Filozoficzne Aspekty Genezy 2004, t. 1, s. 63-64 [55-64], https://tiny.pl/thtcp (25.11.2018).

${ }^{160}$ Krytyczną ocenę opinii Behe'ego dotyczacej Doolittle'a odnaleźć można u Bartosza BoRCZYKA, „Dlaczego teoria ewolucji jest ważna”, s. 21-22 [1-26], https://tiny.pl/g262s (25.11.2018).

${ }^{161}$ Por. RenNIE, „15 odpowiedzi...”, s. 72.
} 
czym są układy nieredukowalnie złożone. ${ }^{162}$

Opisany przed chwilą stan rzeczy doczekał się następującej oceny:

przez wiele lat [neodarwinizm] wydawał mi się [...] wiarygodną teorią, ponieważ polegałem wtedy na ekspertyzie innych osób pracujących w moim zawodzie. ${ }^{163}$

Wyrażając to językiem Lakatosa i Feyerabenda, powiedzieć można, że naturalizm metodologiczny jest składnikiem „potocznej mądrości naukowej”, która „nie jest wcale taka mądra”. ${ }^{164}$

Opieranie się na autorytecie nie jest cechą, która charakteryzuje wyłącznie naturalistów. Teoretykom projektu można postawić podobny zarzut. W jednej ze swoich prac Michael Polanyi utrzymywał, że niektóre struktury organizmów żywych wydają się nieredukowalne do praw fizyki i chemii. Behe, Dembski i Thaxton dla wsparcia własnych racji powołują się teraz na przekonania Polanyiego. ${ }^{165}$ Zaś klasycznym przykładem skutków podążania za autorytetem jest następująca wypowiedź Keplera:

Mój [...] błąd polegał na tym, że tor planety uważałem za doskonałe koło, a pomyłka ta kosztowała mnie tym więcej czasu, że tak nauczano w oparciu o autorytet wszystkich filozofów, a samo w sobie było to zgodne z metafizyką. ${ }^{166}$

Opieranie się na autorytecie ${ }^{167}$ jest następstwem określonego sposobu kształcenia, jakiego nie można odnaleźć nigdzie poza obrębem nauk przyrodni-

\footnotetext{
${ }^{162}$ Por. Behe, „Nieredukowalna złożoność...”, s. 88-89.

${ }^{163}$ Wypowiedź Michaela Behe'ego w: Mark RYLAND, , «Teoria inteligentnego projektu» podważa teorię ewolucji. Już sama złożoność stworzenia świadczy o działaniu siły wyższej. Darwinizm? Nie ma szans. Wywiad z Michaelem J. Behe'em dla Our Sunday Visitor", przeł. Dariusz Sagan, Na Poczatku... 2004, nr 11-12A (187-188), s. 416 [414-420], https://tiny.pl/g2vmb (25. 11.2018). Por. też SAGAN, Spór o nieredukowalną złożoność..., s. 184 przyp. 682.

${ }^{164}$ Por. Feyerabend, „Krytyka naukowego...”, s. 169-171; Feyerabend, Against Method..., s. 189, 202-203, 207.

${ }^{165}$ Por. Jonathan WITt, „Zarys historii powstania naukowej teorii inteligentnego projektu”, przeł. Dariusz Sagan, Na Poczatku ... 2005, nr 9-10 (198-199), s. 353-354 [352-362], https://tiny. $\mathrm{pl} / \mathrm{xhh} 8 \mathrm{q}(25.11 .2018)$.

${ }^{166}$ Cyt. za: A. Rupert HALL, Rewolucja naukowa 1500-1800. Ksztaltowanie się nowożytnej postawy naukowej, przeł. Tadeusz Zembrzuski, Instytut Wydawniczy PAX, Warszawa 1966, s. 154-155. Por. też JANKowski, „Ewolucja pojęcia...”, s. 223-224.
} 
czych. ${ }^{168}$ Cechą charakterystyczną naukowej edukacji jest wykształcenie $\mathrm{u}$ adeptów wyjątkowo silnego zaangażowania w określony sposób postrzegania świata, jaki niesie za sobą paradygmat:

reprezentant nauki normalnej winien być bezkrytyczny wobec paradygmatu, w ramach którego pracuje. ${ }^{169}$

To, czy zachodzenie takiego stanu rzeczy jest czymś, co hamuje czy też przyspiesza wzrost wiedzy, jest oczywiście kwestią dyskusyjną i wiąże się z krytyką Kuhnowskiej koncepcji nauki normalnej. ${ }^{170}$

\footnotetext{
${ }^{167}$ Nie wszyscy dostrzegają ten fakt:
}

W fizyce nie ma miejsca na żadne autorytety. Integralną cechą nowoczesnej fizyki jest jej elastyczność i zmienność. Nie ma większego znaczenia to, co powiedział najmądrzejszy człowiek, jeżeli doświadczenie tego nie potwierdza.

Zbigniew JACYNA-ONYSZKIEWICZ, „Nauka a wiara” (Wykład inauguracyjny w Instytucie Studiów nad Rodziną UKSW w Łomiankach, dn. 13.10.2003 r.), https://tiny.pl/thtdx (25.11.2018).

Naukowa metoda poszukiwania prawdy opiera się na: rozumie, badaniach empirycznych, krytycyzmie, wątpliwościach, przewidywaniach, powtarzalności obserwacji przez różnych badaczy. Dzięki temu jest niezgodna z religijnymi metodami rozumienia wszechświata: metodami bazującymi na dogmatach, autorytecie i objawieniu.

Jerry A. Coyne, „Science, Religion, and Society: The Problem of Evolution in America”, Evolution. International Journal of Organic Evolution 2012, vol. 66, no. 8, s. 2656 [2654-2663], https://tiny.pl/thtdt (25.11.2018).

${ }^{168}$ Pedagogika i teologia to, zdaniem Kuhna, wyjątki, które są w swoim kształceniu tak samo dogmatyczne jak przyrodoznawstwo (por. KuHN, „The Function of Dogma...”, s. 350. Por. też wypowiedź Thomasa Kuhna w: Aristides Baltas, Kostas Gavroglu i Vassiliki Kindi, „Rozmowa z T.S. Kuhnem”, w: Kunn, Droga po Strukturze..., s. 280 [235-293]).

${ }^{169}$ Alan F. Chalmers, Czym jest to, co zwiemy nauką? Rozważania o naturze, statusie i metodach nauki. Wprowadzenie do współczesnej filozofii nauki, przeł. Adam Chmielewski, Wydawnictwo SIEDMIORÓG, Wrocław 1993, s. 125.

${ }^{170}$ Por. np. John W.N. Watkins, „Against «Normal Science»”, w: Imre LaKatos and Alan Musgrave (eds.), Criticism and the Growth of Knowledge, Cambridge University Press, Cambridge 1970, s. 28-29 [25-38]; LaKatos, „Falsyfikacja a metodologia...”, s. 5; FeYerabend, „Ku pocieszeniu...”, s. 201-202, 205-206, 217-218; FeYerabend, „Problems of Empiricism...”, s. 172; Karl R. Popper, „Replies To My Critics”, w: Paul A. Schilpp (ed.), The Philosophy of Karl Popper, The Library of Living Philosophers, vol. 14, Open Court, La Salle, Illinois 1974, s. 11441148 [961-1197]; Karl R. Popper, „Racjonalność rewolucji”, w: Karl R. Popper, Mit schematu po- 


\section{Podsumowanie}

W artykule zostały przebadane pod kątem ich zasadności krytyczne argumenty wobec naturalizmu metodologicznego. Zostały też uporządkowane w następujące grupy:

Naturalizm źle wpływa na rozwój wiedzy, gdyż ogranicza badania naukowe. Na rzecz tej tezy argumentowano rozmaicie:

— naturalizm stoi na przeszkodzie owocnego dialogu między nauką i religią, gdyż: uniemożliwia naukową dyskusję nad wieloma istotnymi kwestiami, w tym nad ludzką wolnością, moralnością, celowością w przyrodzie i Bogiem; cudy są integralnym elementem realnych religii, a naturalistycznie uprawiana nauka wyklucza zachodzenie cudów;

- przyjmowanie wyłącznie naturalistycznych wyjaśnień utrudnia podążanie za danymi empirycznymi, gdyż obstawanie przy jednej perspektywie teoretycznej skutecznie utrudnia dostrzeżenie tych faktów, które mogą wyjść na jaw dopiero wtedy, gdy poważnie potraktuje się alternatywne punkty widzenia;

- przyjmowanie jedynie naturalistycznych wyjaśnień uniemożliwia bezstronne rozpatrywanie świadectw;

- naturalizm sugeruje, że nie istnieje sfera nadprzyrodzona, a to wcale nie jest takie pewne (,nie jesteśmy pewni, że to, co nadnaturalne nie istnieje”);

- należy określić okres czasu, po którego upływie zrezygnować należy z naturalizmu, gdy nie przynosi on zamierzonych efektów;

- naturalizm a priori wyklucza wyjaśnienia nienaturalistyczne, podczas gdy o wiele bardziej przekonujące są wykluczenia aposterioryczne.

W myśl kolejnej tezy naturalizm utrudnia współzawodnictwo w nauce. Przejawia się to $\mathrm{w}$ tym, że, wykluczając $\mathrm{z}$ obrębu nauki wszelkie nienaturali-

jęciowego. W obronie nauki i racjonalności, przeł. Bohdan Chwedeńczuk, Książka i Wiedza, Warszawa 1997, s. 28-29 [13-40]; Henryk SкоLıмоwsкi, „Evolutionary Rationality”, PSA: Proceedings of the Biennial Meeting of the Philosophy of Science Association 1974, s. 196-197 [191213]; Zygmunt HAJDUK, Temporalność nauki, Redakcja Wydawnictw Katolickiego Uniwersytetu Lubelskiego, Lublin 1995, s. 71-73, 79; Kazimierz JodKowski, „Popper a Kuhn w sprawie wzrostu wiedzy”, Zagadnienia Naukoznawstwa 1990, t. 26, z. 3, s. 466-467 [463-468]. 
styczne wyjaśnienia, sugeruje, iż poszukiwanie alternatywnych względem naturalizmu rozwiązań jest zbyteczne. W efekcie promuje naukowe lenistwo.

Następna teza głosi, że naturalizm jest częścią fundamentalistycznej, oświeceniowej tradycji - wyznaczania określonej relacji między wiarą (sferą subiektywnych przekonań) a rozumem (sferą identycznych dla wszystkich ludzi, a przez to obiektywnych, przekonań) - która pochopnie została zabsolutyzowana. W uzasadnieniu tej tezy podkreśla się, że fundamentalizm ten jest już podejściem przestarzałym.

Zgodnie z inną tezą naturalizm jest jedynie prowizoryczną zasadą, nie zaś warunkiem koniecznym uprawiania nauki. Na rzecz powyższej tezy argumentowano tak:

— nie istnieje powszechnie akceptowana definicja nauki, zatem naturalizm jest jedynie jednym z możliwych podejść do nauki;

— naturalizm jest jedynie indukcyjnym uogólnieniem, efektem 300-400 lat praktyki naukowej, zaś argumenty indukcyjne nie dowodzą swoich wniosków w sposób pewny.

Wedle jeszcze innej tezy naturalizm jest arbitralną, dogmatyczną i szkodliwą regułą. Tezę tę wspierano następującymi argumentami:

— nauka nie jest grą, dopuszczającą arbitralne reguły akceptacji wyjaśnień; zadaniem tej pierwszej jest próba formułowania prawdziwych twierdzeń o świecie;

— dogmaty nie wchodzą w skład nauki.

W myśl kolejnej tezy naturalizm jest podejściem irracjonalnym. Na jej rzecz argumentowano, twierdząc, że de facto nie jest możliwe dostarczenie naturalistycznych wyjaśnień dla wszystkich zjawisk, zatem uparte obstawanie przy naturalizmie jest podejściem irracjonalnym.

Zgodnie z następną tezą naturalizm jest jedynie kiepską filozofią. Na rzecz tej tezy argumentowano tak:

— nie jest to, bazujący na świadectwach empirycznych, pogląd naukowy;

— naturalizm prowadzi do naukowego antyrealizmu, w ramach którego - 
podobnie jak w idealizmie - rzeczywistość musi się zgadzać z ideami, co w tym konkretnym przypadku oznacza, że interpretacja świadectw empirycznych dostosować się musi do wymogów naturalizmu metodologicznego;

- naturalizm nie uwalnia nauki od balastu metafizycznego; tego ostatniego pozbyć się można, przyjmując metafizyczny neutralizm (powstrzymywanie się od wygłaszania przekonań na temat sposobu istnienia świata).

Wedle ostatniej badanej tu tezy naturalizm jest ujęciem przyjmowanym bezkrytycznie. Dzieje się tak, ponieważ opiera się on na autorytecie (zdarza się, że wyjaśnienia naturalistyczne są efektem pochopnego przyswajania, przedstawianych przez autorytety w danej dziedzinie, błędnych argumentów).

Podsumowując rozważania nad omówionymi w artykule argumentami zauważyć należy, że sporą część przedstawionych tu argumentów dałoby się uzgodnić z anarchizmem epistemologicznym i jego przesłaniem. Feyerabend propagował swoje anarchistyczne poglądy nie po to, by rozwijać naukę, lecz po to, by bronić tego, co bezmyślnie jest niszczone:

Siłą napędową mojej pracy był i pozostaje gniew — spowodowany rozmyślnym niszczeniem osiągnięć kulturowych, z których wszyscy moglibyśmy się uczyć, zarozumiałą pewnością, z jaką niektórzy intelektualiści ingerują w ludzkie życie - oraz moja pogarda dla przesłodzonych zwrotów, którymi się posługują, aby upiększyć swoje karygodne czyny. ${ }^{171}$

Antynaturaliści, mimo tego, iż dość obszernie czerpią ze współczesnej filozofii nauki, nie szukają wsparcia w Feyerabendowskim anarchizmie, który bardzo dobrze nadaje się na narzędzie obrony przeciwko hegemonii myślenia naturalistycznego. W duchu anarchistycznym można bowiem twierdzić, że filozoficzne przekonanie, iż istnieje - spajany pojęciem metodologicznego naturalizmu - monolit zwany nauką, jest błędne. ${ }^{172} \mathrm{Na}$ rzecz tego poglądu podawać można przykłady obecności artyficjalistycznych wyjaśnień w nauce (archeologia) i przedsięwzięciach naukowych (program SETI). Zgodne z anarchizmem jest również przekonanie, w myśl którego nie istnieje taka definicja nauki, która

\footnotetext{
${ }^{171}$ Feyerabend, Przeciw metodzie..., s. 252.

${ }^{172}$ Por. wypowiedź Paula Feyerabenda w: Parascandalo and Hösle, „Three Interviews...”, s. 118; por. też Feyerabend, The Tyranny..., s. 55-56.
} 
jest w stanie objąć wszystkie przekształcenia, jakim ulega nauka. ${ }^{173}$ Anarchizm przestrzega też przed permanentnym ograniczaniem pojęcia racjonalności naukowej do jakiegoś wyraźnie wyartykułowanego i ponadhistorycznego zbioru reguł, za którym zawsze należy podążać, gdyż jest to podejście dla nauki szkodliwe. ${ }^{174}$ Postępowanie uczonych, którzy od takich reguł odstępują, nie jest irracjonalne. (Może być za takie uznane jedynie w perspektywie niektórych narzucanych na naukę standardów. ${ }^{175}$ ) Takie działania uczonych można ,racjonalnie wytłumaczyć", czyli powiedzieć, dlaczego uczeni, w konkretnych okolicznościach, postąpili tak, a nie inaczej. ${ }^{176}$ Pojmowany w ten sposób anarchizm, sugerujący, by próbować wszystkiego i patrzeć, czy się w konkretnych okolicznościach przyda, ${ }^{177}$ nie ma na celu wyeliminowania podejścia naturalistycznego. Dostosowywane do konkretnej sytuacji praktyczne reguły zastępują tu jedynie zakładane przez innych filozofów uniwersalne standardy. ${ }^{178}$

Możliwe są dwa wyjaśnienia tego stanu rzeczy: relatywizm Feyerabenda ${ }^{179}$

\footnotetext{
${ }^{173}$ Por. Paul K. Feyerabend, „Podsumowująca niefilozoficzna leśna przechadzka”, w: FeYerABEND, Dialogi o wiedzy..., s. 129 [77-142].

${ }^{174}$ Por. wypowiedź Paula Feyerabenda w: Jung, „Paul K. Feyerabend...”, s. 162.

${ }^{175}$ Por. Feyerabend, „Podsumowująca niefilozoficzna...”, s. 106.

${ }^{176}$ List Paula K. Feyerabenda do Isaaca Ben-Israela z 22 stycznia 1989 roku w: Isaac BeNIsRaEL, „Philosophy and Methodology of Military Intelligence: Correspondence with Paul Feyerabend", Philosophia 2001, vol. 28, nos. 1-4, s. 80 [71-101].

${ }^{177}$ Por. Marx W. Wartofsky, „How to Be a Good Realist”, w: Gonzalo Munévar (ed.), Beyond Reason: Essays on the Philosophy of Paul K. Feyerabend, Boston Studies in the Philosophy of Science, vol. 132, Kluwer Academic Publishers, Dordrecht - Boston - London 1991, s. 28 [25-40].

${ }^{178}$ Por. Feyerabend, The Tyranny..., s. 121.

${ }^{179}$ Feyerabend niezwykle rzadko expressis verbis formułował swoje stanowisko. Do relatywizmu przyznał się jednak wprost:

Ciągle jednak różnię się od niego [Kuhna] tym, że jestem relatywistą.

Feyerabend, Przeciw metodzie..., s. 216.

W innym miejscu Feyerabend napisał tak:

Mój tak zwany relatywizm.
} 
lub też jego nieukrywany szacunek dla klasyków marksizmu-leninizmu: ${ }^{180}$

mówię sobie „wróć do Marksa” i ponownie zbadaj, co może zostać zachowane z „formalnej demokracji”, co odgrywa taką samą rolę w polityce, jaką argument odgrywa $\mathrm{w}$ astronomii. ${ }^{181}$

będę znany jako Engels dwudziestego wieku. ${ }^{182}$

taka jednostka jak Lenin, której nie ośmielają tradycyjne ograniczenia i której myślenie nie jest związane z ideologią konkretnego zawodu, może dostarczyć pożytecznych rad każdemu, z filozofami nauki włącznie. ${ }^{183}$

Cytuję Lenina z powodu jego wglądu w złożoność warunków historycznych, który jest nieporównywalnie głębszy od wglądu uczonych i filozofów nauki, oraz dlatego, że zaleca on odpowiednio złożoną metodę. [...] Zalecam Luxemburg, ponieważ na pierwszym miejscu jej metody jest jednostka, czego nie można powiedzieć o Popperze. Cy-

Feyerabend, „Podsumowująca niefilozoficzna...”, s. 107 [wyróżnienie w oryginale].

Problem w tym, że słowo „relatywizm”, jak wiele określeń filozoficznych, jest wieloznaczne, i o ile przyznaję, że w pewnym sensie jestem żarliwym relatywistą, o tyle w innym rozumieniu z pewnością relatywistą nie jestem.

Feyerabend, „Podsumowująca niefilozoficzna...”, s. 114.

Feyerabendowi przypisuje się bardzo radykalne poglądy, na przykład, że „każdy punkt widzenia jest równie dobry, jak inny". Pomimo tego, że nie jest łatwo jednoznacznie określić stosunek Feyerabenda do relatywizmu i jego odmian (por. np. John Preston, „Science as Supermarket: «Postmodern» Themes in Paul Feyerabend's Later Philosophy of Science”, w: Preston, Munévar, and Lamb (eds.), The Worst Enemy..., s. 90-94 [80-101]; Krzysztof J. KiLian, Poglądy filozoficzne Paula K. Feyerabenda. Część I. Program metodologiczny, Oficyna Wydawnicza Uniwersytetu Zielonogórskiego, Zielona Góra 2014, s. 10-11, 268 przyp. 1203, 297-298), to takiej deklaracji nie da się odnaleźć w jego pismach (por. w tej sprawie FeYerabend, „Podsumowująca niefilozoficzna...”, s. 107, Preston, „Science as Supermarket...”, s. 91).

${ }^{180}$ Szacunek ten zauważył na przykład Imre Lakatos, nazywając Feyerabenda „autentycznym anarchistą marksistowskiej filozofii nauki" (por. list Imrego Lakatosa do Paula K. Feyerabenda z 20 listopada 1970 roku w: Imre Lakatos and Paul Feyerabend, For and Against Method: Including Lakatos's Lectures on Scientific Method and the Lakatos-Feyerabend Correspondence, ed. Matteo Motterlini, The University of Chicago Press, Chicago and London 1999, s. 220).

${ }^{181}$ List Paula K. Feyerabenda do Imrego Lakatosa z 4 września 1968 roku w: LAKATos and Feyerabend, For and Against..., s. 151-152.

${ }^{182}$ List Paula K. Feyerabenda do Imrego Lakatosa z 18 grudnia 1970 roku w: LAKATos and Feyerabend, For and Against..., s. 231.

${ }^{183}$ Feyerabend, „Against Method...”, s. 94-95 przyp. 5. 
tuję Mao, ponieważ jest on gotów porzucić, nawet w zasadniczych sprawach, doktrynę na rzecz doświadczenia. ${ }^{184}$

Znaczna cześć antynaturalistów to chrześcijanie, dla których relatywizm i lewicowość leżą daleko poza ich światopoglądami. I zapewne dlatego nawet te najbardziej konstruktywne wątki Feyerabendowskiego anarchizmu — w których mówiąc, że „wszystko się może przydać”, chciał wskazać, iż „żadna interesująca idea nigdy nie zostaje całkowicie sthumiona, bez względu na to, jak mało za nią przemawia", ${ }^{185} \mathrm{i}$ że obstawanie przy tezie, iż wszystko może się przydać, nie zawsze jest pomocne w pracy naukowej (ponieważ w uprawianiu nauki przeszkadza dosłownie każdy slogan, włączając w to jego własny, gdy nie jest przystosowany do określonej sytuacji badawczej ${ }^{186}$ ) — są dla nich niezwykle trudne do zaakceptowania.

Krzysztof J. Kilian

\section{Bibliografia}

Ackerman Paul D. and Williams Bob, Kansas Tornado: The 1999 Science Curriculum Standards Battle, Institute for Creation Research, El Cajon, California 1999.

Ajdukiewicz Kazimierz, „Franciszek Bacon z Werulamu — Dzieło i życie”, w: BACon, Novum Organum..., s. vii-xciv.

ApPlEgate Kathryn, „A Defense of Methodological Naturalism”, Perspectives on Science and Christian Faith 2013, vol. 65, no. 1, s. 37-45, https://tiny.pl/xh8tg (24.11.2018).

Arystoteles, Metafizyka, przeł. Tadeusz A. Żeleźnik, Redakcja Wydawnictw KUL, Lublin 1986.

Ayala Francisco J., „Darwin’s Revolution”, w: Campbell and Schopf (eds.), Creative Evolution..., s. 1-18.

\footnotetext{
${ }^{184}$ FeYerabend, „Against Method...”, s. 105 przyp. 38. Feyerabend zdawał sobie sprawę $\mathrm{z}$ tego, że nawiązania do Lenina nie przysporzą mu sympatyków (por. list Paula K. Feyerabenda do Imrego Lakatosa z 18 listopada 1968 roku w: LaKatos and Feyerabend, For and Against..., s. 153).

${ }^{185}$ Por. FeYerabend, „Podsumowująca niefilozoficzna...”, s. 89.

${ }^{186}$ Por. Feyerabend, „Podsumowująca niefilozoficzna...”, s. 107. Por. też Kilian, Poglądy filozoficzne..., s. 138-139.
} 
BaCon Francis, Novum Organum, przeł. Jan Wikarjak, Państwowe Wydawnictwo Naukowe, Warszawa 1955

Baltas Aristides, Gavroglu Kostas i Kindi Vassiliki, „Rozmowa z T.S. Kuhnem”, w: KuHn, Droga po Strukturze..., s. 235-293.

BARTLETT Jonathan, „Filozoficzne wady naturalizmu metodologicznego i perspektywy na przyszłość", przeł. Dariusz Sagan, Filozoficzne Aspekty Genezy 2017, t. 14, s. 53-87, https://tiny.pl/thd7j (16.01.2019).

BARTLETt Jonathan, „Philosophical Shortcomings of Methodological Naturalism and the Path Forward", w: BaRTLETT and Holloway (eds.), Naturalism and Its Alternatives..., s. 13-37, https://tiny.pl/gkdb2 (23.11.2018).

Bartlett Jonathan and Holloway Eric, „Introduction”, w: Bartlett and Holloway (eds.), Naturalism and Its Alternatives..., s. 1-9.

Bartlett Jonathan and Holloway Eric (eds.), Naturalism and Its Alternatives in Scientific Methodologies: Proceedings of the 2016 Conference on Alternatives to Methodological Naturalism, Blyth Institute Press, Broken Arrow, Oklahoma 2017.

BAtens Diderik, „Pluralism in Scientific Problem Solving: Why Inconsistency Is No Big Deal”, Humana. Mente Journal of Philosophical Studies 2017, vol. 32, s. 149-177, https://ti ny.pl/thmzk (23.11.2018).

BAuEr Henry H., Dogmatism in Science and Medicine: How Dominant Theories Monopolize Research and Stifle the Search for Truth, McFarland \& Company, Jefferson 2012.

BAuER Henry H., Scientific Literacy and the Myth of the Scientific Method, University of Illinois Press, Urbana and Chicago 1994.

BEGLEy Sharon, „Heretics in the Laboratory”, Newsweek 15 September 1996, s. 82, https:// tiny.pl/txgnw (15.01.2019).

BeHE Michael J., Czarna skrzynka Darwina. Biochemiczne wyzwanie dla ewolucjonizmu, przeł. Dariusz Sagan, Biblioteka Filozoficznych Aspektów Genezy, t. 4, Wydawnictwo MEGAS, Warszawa 2008.

BeHE Michael J., „Filozoficzne zarzuty stawiane hipotezie inteligentnego projektu: odpowiedź na krytykę", przeł. Dariusz Sagan, Filozoficzne Aspekty Genezy 2004, t. 1, s. 115139, https://tiny.pl/gt9nw (24.11.2018).

Bene Michael J., „Nieredukowalna złożoność: problem dla ewolucjonizmu darwinowskiego", przeł. Dariusz Sagan, Filozoficzne Aspekty Genezy 2005/2006, t. 2/3, s. 67-96, https:// tiny.pl/qzq8n (23.11.2018). 
BEHE Michael J., „Precyzyjny projekt: powstawanie biologicznych mechanizmów molekularnych”, przeł. Dariusz Sagan, Na Początku... 2004, nr 5-6 (181-182), s. 163-183, https:// tiny.pl/glntc (24.11.2018).

BEHE Michael J., „Współczesna hipoteza inteligentnego projektu. Łamanie reguł”, przeł. Dariusz Sagan, Na Początku... 2004, nr 7-8 (183-184), s. 244-266, https://tiny.pl/g2sml (24.11.2018).

Ben-Israel Isaac, „Philosophy and Methodology of Military Intelligence: Correspondence with Paul Feyerabend", Philosophia 2001, vol. 28, nos. 1-4, s. 71-101.

Berman Marshall, „Intelligent Design Creationism: A Threat to Society — Not Just Biology", The American Biology Teacher 2003, vol. 65, no. 9, s. 646-648, https://tiny.pl/g26n5 (15.01.2019).

Bogen James, „Experiment and Observation”, w: Machamer and Silberstein (eds.), The Blackwell Guide..., s. 128-148.

Borczyк Bartosz, „Dlaczego teoria ewolucji jest ważna”, s. 1-26, https://tiny.pl/g262s (25. 11.2018).

Borczyk Bartosz, Chmielewski Adam, Elżanowski Andrzej, Jodkowski Kazimierz, LeszCZyŃSki Damian, Lukierski Jerzy, Nysler Łukasz i PawŁowski Bogusław, „Dyskusja”, w: LesZCZYŃSKi (red.), Ewolucja. Filozofia. Religia..., s. 155-172, https://tiny.pl/xh8gj (24.11. 2018).

BRAND Leonard, „Naturalizm i jego rola w nauce”, przeł. Paulina Korzeniewska-Nowakowska, Filozoficzne Aspekty Genezy 2016, t. 13, s. 49-74, https://tiny.pl/g2sg3 (23.11.2018).

Brown J.R. i Davies P.C.W., Duch w atomie. Dyskusja o paradoksach teorii kwantowej, przeł. Piotr Amsterdamski, Wydawnictwo CIS, Warszawa 1996.

Brożex Anna, Chybińska Alicja, Grygianiec Mariusz i Tkaczyk Marcin (red.), Myśli o języku, nauce i wartościach. Seria druga. Profesorowi Jackowi Juliuszowi Jadackiemu w siedemdziesiątą rocznicę urodzin, Wydawnictwo Naukowe Semper, Warszawa 2016.

Buckna David, „Do Creationists Publish in Notable Refereed Journals?”, Creation Ministries International April 1997, https://tiny.pl/tqrjs (15.01.2019).

Bugge T.H., Kombrinck K.W., Flick M.J., Daugherty C.C., Danton M.J., and Degen J.L., „Loss of Fibrinogen Rescues Mice from the Pleiotropic Effects of Plasminogen Deficiency", Cell 1996, vol. 87, s. 709-719.

Butryn Stanisław (red.), Z zagadnień filozofii nauk przyrodniczych, Polska Akademia Nauk, Instytut Filozofii i Socjologii, Warszawa 1991.

Bylica Piotr, Gazda Małgorzata, Jodkowski Kazimierz, Kilian Krzysztof J. i Sagan Dariusz, „Dyskusja nad artykułem Adama Trybusa, «Program badawczy SETI a teoria inteli- 
gentnego projektu»", Filozoficzne Aspekty Genezy 2016, t. 13, s. 211-242, https://tiny.pl/g8 nvh (24.12.2018).

Bylica Piotr, Jodkowski Kazimierz, Kilian Krzysztof J. i Sagan Dariusz, „Dyskusja nad artykułem Adama Groblera, «Słabości eksplanacyjne teorii inteligentnego projektu»", Filozoficzne Aspekty Genezy 2013, t. 10, s. 17-63, https://tiny.pl/tx9ht (16.01.2019).

Bylica Piotr, Kilian Krzysztof J., Piotrowski Robert i Sagan Dariusz (red.), Filozofia nauka - religia. Księga jubileuszowa dedykowana Profesorowi Kazimierzowi Jodkowskiemu z okazji 40-lecia pracy naukowej, Oficyna Wydawnicza Uniwersytetu Zielonogórskiego, Zielona Góra 2015.

Campbell John H. and Schopf J.W. (eds.), Creative Evolution!?, Jones and Bartlett, New York 1994.

Chalmers Alan F., Czym jest to, co zwiemy nauką? Rozważania o naturze, statusie i metodach nauki. Wprowadzenie do wspólczesnej filozofii nauki, przeł. Adam Chmielewski, Wydawnictwo SIEDMIORÓG, Wrocław 1993.

Colodny Robert G. (ed.), Beyond the Edge of Certainty: Essays in Contemporary Science and Philosophy, Prentice-Hall, Englewood Cliffs, New Jersey 1965.

Coyne Jerry A., „Science, Religion, and Society: The Problem of Evolution in America”, Evolution. International Journal of Organic Evolution 2012, vol. 66, no. 8, s. 2654-2663, https://tiny.pl/thtdt (25.11.2018).

Coyne George V. and Heller (Michał) Michael, A Comprehensible Universe: The Interplay of Science and Theology, Springer-Verlag, New York 2008.

Crombie Alistair Cameron (ed.), Scientific Change: Historical Studies in the Intellectual, Social and Technical Conditions for Scientific Discovery and Technical Invention, from Antiquity to The Present, Symposium on the History of Science, University of Oxford 9-15 July 1961, Heinemann, London 1963.

DARwin Karol, Autobiografia i wybór listów. Dzieła wybrane, t. 8, przeł. A. Iwanowska, A. Krasicka, J. Połtowicz i S. Skowron, Państwowe Wydawnictwo Rolnicze i Leśne, Warszawa 1960.

DARWIN Karol, O powstawaniu gatunków drogą doboru naturalnego, czyli o utrzymaniu się doskonalszych ras w walce o byt. Dzieła wybrane, t. 2, przeł. Szymon Dickstein i Józef Nusbaum, Państwowe Wydawnictwo Rolnicze i Leśne, Warszawa 1959.

DAvies Paul, „Fizyka i umysł Boga. Przemówienie na uroczystości wręczenia Nagrody Templetona”, przeł. Joanna Popek, Filozoficzne Aspekty Genezy 2011, t. 8, s. 7-21, https://ti ny.pl/xhnlk (22.03.2017).

Dean Cornelia, „Faith, Reason, God and Other Imponderables”, The New York Times 25 July 2006, https://tiny.pl/gsx76 (25.11.2018). 
Deborin Abram, „Krytyka empiriomonizmu Bogdanowa”, przeł. W. Jankowski, Samokształceniowe Koło Filozofii Marksistowskiej, Warszawa 2008, s. 1-9, https://iny.pl/gz6j3 (25.11.2018).

Delfino Robert A., „Naturalizm metodologiczny i ewolucja”, przeł. Rafał Lizut, w: JAROSZYŃSKI (red.), Ewolucjonizm czy kreacjonizm..., s. 137-156.

Delfino Robert A., „Replacing Methodological Naturalism”, Metanexus 24 May 2007, https://tiny.pl/thmmz (23.11.2018).

Delfino Robert A., „Zastąpić metodologiczny naturalizm”, s. 1-12, https://tiny.pl/hkjt1 (23. 11.2018).

Dembski William A., „Odmiany naturalizmu. Czy któraś forma naturalizmu jest zgodna z teorią inteligentnego projektu?", przeł. Dariusz Sagan, Na Poczatku ... 2005, nr 1-2, s. $45-$ 54, https://tiny.pl/xhkg8 (23.11.2018).

Dembski William A., „On the Very Possibility of Intelligent Design”, w: Moreland (ed.), The Creation Hypothesis..., s. 113-139.

Dembski William A., „Powrót projektu do nauk przyrodniczych”, przeł. Dariusz Sagan, $\mathrm{Na}$ Początku... 2004, nr 9-10 (185-186), s. 323-342, https://tiny.pl/thmgz (23.11.2018).

Dembski William A. and Kushiner James M. (eds.), Signs of Intelligence: Understanding Intelligent Design, Brazos Press, Grand Rapids 2001.

Doolittle Russell F., „Subtelna równowaga”, przeł. Dariusz Sagan, Filozoficzne Aspekty Genezy 2004, t. 1, s. 55-64, https://tiny.pl/thtcp (25.11.2018).

Dose Klaus, „The Origin of Life: More Questions Than Answers”, Interdisciplinary Science Reviews 1988, vol. 13, no. 4, s. 348-356.

DuнEм Pierre, „Kilka refleksji na temat fizyki eksperymentalnej”, przeł. Monika Sakowska, w: SzlachCic, Filozofia nauki..., s. 17-52.

Duнem Pierre, „La théorie physique — son objet, et sa structure”, przeł. Monika Sakowska, w: SzLACHCIC, Filozofia nauk empirycznych..., s. W36-W95.

Eldredge Niles, The Triumph of Evolution and the Failure of Creationism, W.H. Freeman and Company, New York 2001.

ENGELs Fryderyk, Dialektyka przyrody, przeł. Tadeusz Zabłudowski, Państwowe Wydawnictwo Naukowe, Warszawa 1979.

Feyerabend Paul K., Against Method: Outline of an Anarchistic Theory of Knowledge, New Left Books, London 1975.

Feyerabend Paul K., „Against Method: Outline of an Anarchistic Theory of Knowledge”, w: Radner and Winokur (eds.), Analyses of Theories..., s. 17-130. 
Feyerabend Paul K., „Dialectical Materialism and the Quantum Theory”, Slavic Review 1966, vol. 25, no. 3, s. 414-417.

Feyerabend Paul K., Dialogi o wiedzy, przeł. Justyna Nowotniak, Fundacja Aletheia, Warszawa 1999

Feyerabend Paul K., „Fantazje platońskie”, w: Feyerabend, Dialogi o wiedzy..., s. 5-76.

Feyerabend Paul K., Jak być dobrym empirystą, przeł. Krystyna Zamiara, Państwowe Wydawnictwo Naukowe, Warszawa 1979.

FeYerabend Paul K., „Jak być dobrym empirystą? Wezwanie do tolerancji w kwestiach epistemologicznych", w: FEYERABEND, Jak być dobrym empirystą..., s. 23-61.

Feyerabend Paul K., „Krytyka naukowego rozumu”, przeł. Edmund Mokrzycki, w: MoKRZYCKI (red.), Racjonalność a styl myślenia..., s. 167-217.

Feyerabend Paul K., „Ku pocieszeniu specjalisty”, w: Feyerabend, Jak być dobrym empirystą..., s. 200-250.

Feyerabend Paul K., „Linguistic Arguments and Scientific Method”, w: Feyerabend, Philosophical Papers. Vol. 1..., s. 146-160.

Feyerabend Paul K., „Outline of a Pluralistic Theory of Knowledge and Action”, w: FeyerABEND, Philosophical Papers. Vol. 3..., s. 104-111.

Feyerabend Paul K., Philosophical Papers. Vol. 1. Realism, Rationalism \& Scientific Method, Cambridge University Press, Cambridge - New York — Portchester — Melbourne - Sydney 1981.

Feyerabend Paul K., Philosophical Papers. Vol. 3. Knowledge, Science and Relativism, ed. John Preston, Cambridge University Press, Cambridge - New York - Melbourne Madrid - Cape Town - Singapore - Sao Paulo 1999.

Feyerabend Paul K., „Podsumowująca niefilozoficzna leśna przechadzka”, w: Feyerabend, Dialogi o wiedzy..., s. 77-142.

Paul K. Feyerabend, „The Problem of the Existence of Theoretical Entities”, w: FeyerABEnd, Philosophical Papers. Vol. 3..., s. 16-49.

Feyerabend Paul K., „Problems of Empiricism”, w: Colodny (ed.), Beyond the Edge of Certainty..., s. 145-260.

Feyerabend Paul K., Przeciw metodzie, przeł. Stefan Wiertlewski, Wydawnictwo SIEDMIORÓG, Wrocław 1996.

Feyerabend Paul K., „Reply to Criticism: Comments on Smart, Sellars and Putnam”, w: FeYERABEND, Philosophical Papers. Vol. 1..., s. 104-131. 
Feyerabend Paul K., „Science, Freedom, and the Good Life”, The Philosophical Forum 1968, vol. 1, no. 2, s. 127-135.

Feyerabend Paul K., „,The Theatre as an Instrument of the Criticism of Ideologies: Notes on Ionesco", Inquiry 1967, vol. 10, s. 298-312.

Feyerabend Paul K., The Tyranny of Science, Polity Press, Cambridge UK, Malden USA 2012.

Feyerabend Paul K., „Wyjaśnianie, redukcja i empiryzm”, w: Feyerabend, Jak być dobrym empirystą..., s. 62-151.

Frank Phillip G., The Validation of Scientific Theories, The Beacon Press, Boston 1956.

FRANK Phillip G., „The Variety of Reasons for the Acceptance of Scientific Theories”, w: FRANK, The Validation of Scientific Theories..., s. 3-28.

GAzDa Małgorzata, „Stephena C. Meyera koncepcja «podpisu w komórce» a filozoficzne podstawy nauki”, Filozoficzne Aspekty Genezy 2016, t. 13, s. 7-23, https://tiny.pl/g16kj (15. 01.2019).

GAzDA Małgorzata, „Zasada naturalizmu metodologicznego czy adekwatności przyczynowej?”, Idź Pod Prąd 2015, nr 10-11 (135-136), s. 8-9, https://tiny.pl/tqdbj (15.01.2019).

Gould Stephen Jay, „Epizodyczny charakter zmian ewolucyjnych”, w: Gould, Niewczesny pogrzeb Darwina..., s. 183-200.

Gould Stephen Jay, Niewczesny pogrzeb Darwina. Wybór esejów, przeł. Nina Kancewicz-Hoffman, Biblioteka Myśli Współczesnej, Państwowy Instytut Wydawniczy, Warszawa 1991.

HAJDUK Zygmunt, Temporalność nauki, Redakcja Wydawnictw Katolickiego Uniwersytetu Lubelskiego, Lublin 1995.

Hall A. Rupert, Rewolucja naukowa 1500-1800. Ksztaltowanie się nowożytnej postawy naukowej, przeł. Tadeusz Zembrzuski, Instytut Wydawniczy PAX, Warszawa 1966.

Heller Michał, Ostateczne wyjaśnienia wszechświata, Universitas, Kraków 2008.

Hoyle Fred, Matematyka ewolucji, przeł. Robert Piotrowski, Wydawnictwo MEGAS, Warszawa 2003.

Hume David, Traktat o naturze ludzkiej. Tom I. O umyśle, przeł. Czesław Znamierowski, Nakładem Polskiej Akademii Umiejętności, Kraków 1951.

JACYNA-ONYSZKIEWICZ Zbigniew, „Nauka a wiara” (Wykład inauguracyjny w Instytucie Studiów nad Rodziną UKSW w Łomiankach, dn. 13.10.2003 r.), https://tiny.pl/thtdx (25.11. 2018). 
Janeczek Stanisław, Starościc Anna, DąBek Dariusz i Herda Justyna (red.), Filozofia przyrody, Dydaktyka Filozofii, t. III, Wydawnictwo Katolickiego Uniwersytetu Lubelskiego, Lublin 2013.

JANKOwsKi Krzysztof, „Ewolucja pojęcia paradygmatu w Strukturze rewolucji naukowych Thomasa S. Kuhna”, Sofia. Pismo Filozofów Krajów Stowiańskich 2016, vol. 16, s. 211-228, https://tiny.pl/g3w61 (24.11.2018).

JANKOwsKI Krzysztof, „Paradygmat jako podstawa normalnego uprawiania nauki: nauki społeczne a przyrodoznawstwo. Ujęcie Thomasa Samuela Kuhna”, In Gremium. Studia nad Historia, Kulturą i Polityką 2017, nr 11, s. 193-231.

JaroszyŃski Piotr (red.), Ewolucjonizm czy kreacjonizm, Przyszłość Cywilizacji Zachodu, Fundacja „Lubelska Szkoła Filozofii Chrześcijańskiej”, Lublin 2008.

JoDKоwsкi Kazimierz, „Antynaturalizm teorii inteligentnego projektu”, Roczniki Filozoficzne 2006, t. 54, nr 2, s. 63-76, http://tiny.pl/qzq86 (23.11.2018).

JodKowski Kazimierz, „Curriculum Vitae”, https://tiny.pl/gkfxf (23.11.2018).

Jodкоwsкi Kazimierz, „Dlaczego kreacjonizm jest pseudonauką?”, w: Zon (red.), Pogranicza nauki..., s. 317-323, https://tiny.pl/q3m5b (24.12.2018).

JodKowski Kazimierz, „Dyskordyzm przerywany”, w: BrożeK, ChYBIŃSKA, GrygianieC i ТКАСzүк (red.), Myśli o języku..., s. 592-604.

JODKOwSKI Kazimierz, „Epistemiczny układ odniesienia teorii inteligentnego projektu”, $F i$ lozofia Nauki 2006, nr 1 (53), s. 95-105, https://tiny.pl/q3m5n (24.12.2018).

JoDKowski Kazimierz, „Eskapizm teologii i filozofii katolickiej w sprawie «nauka a religia»", Na Poczatku ... 2005, nr 7-8 (196-197), s. 261-284, https://tiny.pl/gztl8 (24.11.2018).

JoDKowski Kazimierz, „Filozoficzna natura sporu ewolucjonizm-kreacjonizm. Refleksje po lekturze tekstu Phillipa E. Johnsona", Na Początku... 2000, nr 7-8 (131-132), s. 211-217, https://tiny.pl/gzpcc (16.01.2019).

Jodkowski Kazimierz, „Filozofia przyrody a nauki przyrodnicze”, Colloquia Communia 2007, nr 1-2 (82-83), s. 15-22.

JoDKowsкI Kazimierz, „Konflikt nauka-religia a teoria inteligentnego projektu”, w: JoDKowSKI (red.), Teoria inteligentnego projektu..., s. 145-180, https://tiny.pl/qzq8f (23.11. 2018).

JoDKOwSKI Kazimierz, „Kontemplatywny vs. performancyjny model wiedzy a Feyerabendowska krytyka nauki (miejsce nauki w hierarchii wartości różnych tradycji i form życia)", Studia Filozoficzne 1989, nr 10 (287), s. 99-113. 
JoDKowsKi Kazimierz, „Metafizyczne opowieści nauki jako fundament pluralizmu naukowego", w: JoHNSON, Wielka metafizyczna opowieść nauki..., s. 74-85, https://tiny.pl/q3m $5 \mathrm{p}(24.11 .2018)$.

Jodkowski Kazimierz, Metodologiczne aspekty kontrowersji ewolucjonizm-kreacjonizm, Realizm. Racjonalność. Relatywizm, t. 35, Wydawnictwo UMCS, Lublin 1998.

JoDKOwski Kazimierz, „Obserwacja zmysłowa jako postrzeganie wirtualnej rzeczywistości”, w: Kochan (red.), Rzeczywistość wirtualna..., s. 121-153.

JODKOwSKI Kazimierz, „Pojęcie paradygmatu a wspólnotowy charakter nauki w ujęciu Thomasa S. Kuhna”, Annales Universitatis Mariae Curie-Skłodowska 1983, vol. 8, sec. I, s. 4156.

JoDKowski Kazimierz, „Popper a Kuhn w sprawie wzrostu wiedzy”, Zagadnienia Naukoznawstwa 1990, t. 26, z. 3, s. 463-468.

JodKowski Kazimierz, „Radykalna epistemologia”, Studia Filozoficzne 1984, nr 11-12, s. $179-187$.

JodKowski Kazimierz, „Rozpoznawanie genezy: istota sporu ewolucjonizm-kreacjonizm”, Roczniki Filozoficzne 2002, t. 50, z. 3, s. 187-198, https://tiny.pl/xh2bp (15.01.2019).

JoDKowski Kazimierz, „Ruch kreacjonistyczny jest elementem pluralizmu naukowego”, Przeglad Filozoficzny - Nowa Seria 2001, nr 1 (37), s. 241-253, https://tiny.pl/gdw95 (21. 12.2018).

JoDKowsKi Kazimierz, Spór ewolucjonizmu z kreacjonizmem. Podstawowe pojęcia i poglądy, Biblioteka Filozoficznych Aspektów Genezy, t. 1, Wydawnictwo MEGAS, Warszawa 2007, https://tiny.pl/qzq8j (23.11.2018).

JoDKоwsкi Kazimierz (red.), Teoria inteligentnego projektu - nowe rozumienie naukowości?, Biblioteka Filozoficznych Aspektów Genezy, t. 2, Wydawnictwo MEGAS, Warszawa 2007.

JoDKowski Kazimierz, Teza o niewspólmierności w ujęciu Thomasa S. Kuhna i Paula K. Feyerabenda, Realizm. Racjonalność. Relatywizm, t. 1, Wydawnictwo UMCS, Lublin 1984.

Jodkowski Kazimierz, „Twarde jądro ewolucjonizmu”, Roczniki Filozoficzne 2003, t. 51, z. 3, s. 77-117, https://tiny.pl/q3m5j (24.11.2018).

JoDKowski Kazimierz, „Wartości poznawcze w nauce. Wystąpienie w panelu dyskusyjnym", https://tiny.pl/thmzg (23.11.2018).

JODKowsкi Kazimierz, Wspólnoty uczonych, paradygmaty i rewolucje naukowe, Realizm. Racjonalność. Relatywizm, t. 22, Wydawnictwo UMCS, Lublin 1990. 
JoDKowski Kazimierz, „,Wstęp do teorii inteligentnego projektu”, Fronda 2012, nr 63, s. 1632, https://tiny.pl/gkfbn (23.11.2018).

JoDKowsкi Kazimierz, „Zasadnicza nierozstrzygalność sporu ewolucjonizm-kreacjonizm”, Przegląd Filozoficzny - Nowa Seria 2012, nr 3 (83), s. 201-222, https://tiny.pl/gkf57 (23. 11.2018).

JoDKоwsкi Kazimierz, „Z jakim relatywizmem bezskutecznie walczy Wojciech Sady? (Głos w dyskusji)”, w: PoMORSKi (red.), Wartość relatywizmu..., s. 123-146.

Johnson Philipp E., „The Intelligent Design Movement: Challenging the Modernist Monopoly on Science", w: DembSki and Kushiner (eds.), Signs of Intelligence..., s. 25-41.

Johnson Phillip E., „Co to jest darwinizm?”, przeł. Kazimierz Jodkowski, Problemy Genezy 2010, t. 18, s. 103-112, https://tiny.pl/thtmc (16.01.2019).

JoHnson Phillip E., „Evolution as Dogma: The Establishment of Naturalism”, First Things October 1990, https://tiny.pl/thtm9 (24.11.2018).

Johnson Phillip E., Sąd nad Darwinem, przeł. Robert Piotrowski, Oficyna Wydawnicza Vocatio, Warszawa 1997.

JoHnSON Phillip E., Wielka metafizyczna opowieść nauki (z posłowiem Kazimierza Jodkowskiego), przeł. Piotr Bylica, Archiwum Na Początku..., z. 13, Polskie Towarzystwo Kreacjonistyczne, Warszawa 2003.

Jung Joachim, „Paul K. Feyerabend: Last Interview”, w: Preston, MunÉvar, and Lamb (eds.), The Worst Enemy of Science..., s. 159-168.

Kelsen Hans, „Science and Politics”, The American Political Science Review 1951, vol. 45, no. 3, s. 641-661.

KILIAN Krzysztof J., „Argumenty na rzecz naturalizmu jako epistemicznego układu odniesienia", Filozoficzne Aspekty Genezy 2018, t. 15, s. 7-69, https://tiny.pl/txgnc (15.01.2019).

KiLIAN Krzysztof J., „Czym są epistemiczne układy odniesienia?”, Filozoficzne Aspekty Genezy 2017, t. 14, s. 191-236, https://tiny.pl/g8xqp (23.11.2018).

KiLIAN Krzysztof J., „Epistemiczne układy odniesienia a problem interteoretycznej niewspółmierności - część 1", Filozoficzne Aspekty Genezy 2017, t. 14, s. 237-280, https://ti ny.pl/gzx3s (08.10.2018).

KILIAN Krzysztof J., „Epistemiczne układy odniesienia a problem interteoretycznej niewspółmierności - część 2", Filozoficzne Aspekty Genezy 2017, t. 14, s. 281-325, https://ti ny.pl/gzx3v (23.11.2018).

Kilian Krzysztof J., „Filozoficzne podstawy nauki”, Sofia. Pismo Filozofów Krajów Stowiańskich 2015, vol. 15, s. 69-85, https://tiny.pl/gz61z (24.11.2018). 
Kitian Krzysztof J., „Geneza idei epistemicznych układów odniesienia i ich odmiany”, Filozoficzne Aspekty Genezy 2017, t. 14, s. 137-190, https://tiny.pl/gzx34 (23.11.2018).

Kilian Krzysztof J., Poglądy filozoficzne Paula K. Feyerabenda. Część I. Program metodologiczny, Oficyna Wydawnicza Uniwersytetu Zielonogórskiego, Zielona Góra 2014.

Kilian Krzysztof J., „Wzrost wiedzy a zasada tolerancji”, w: Michalczenia, MizińsKa i Ossowska (red.), Poszukiwania filozoficzne..., s. 155-173, https://tiny.pl/tx9m4 (16.01. 2019).

Kоснал Ewa (red.), Rzeczywistość wirtualna. Światy przedstawione w nauce i sztuce, Rozprawy i Studia, t. 522, Wydawnictwo Naukowe Uniwersytetu Szczecińskiego, Szczecin 2005.

KoJonen Erkki V.R., „Methodological Naturalism and the Truth Seeking Objection”, International Journal for Philosophy of Religion 2016, vol. 79, no. 3, s. 1-26, https://tiny.pl/thm r7 (23.11.2018).

KÖHLER Piotr, „,ysenkizm w botanice polskiej”, Kwartalnik Historii Nauki i Techniki 2008, t. $53, \mathrm{nr} 2$, s. $83-161$

Krause Tomasz, ,Filozoficzne aspekty tzw. «afery Kansas»”, Filozoficzne Aspekty Genezy 2004, t. 1, s. 143-224, https://tiny.pl/g2863 (23.11.2018).

Krebs Jack, „The New Science in Kansas Schools Position Paper by Jack Krebs, Kansas Citizens For Science, Science Standards in Kansas: The Real Issues", Kansas Citizens for Science, http://www.kcfs.org.

KuнN Thomas S., Droga po Strukturze. Eseje filozoficzne z lat 1970-1993 i wywiad-rzeka z autorem slynnej „Struktury rewolucji naukowych”, wyd. James Conant i John Haugeland, przeł. Stefan Amsterdamski, Wydawnictwo Sic!, Warszawa 2003.

Kunn Thomas S., „Odpowiedź moim krytykom”, w: Kunn, Droga po Strukturze..., s. 117-162.

Kunn Thomas S., „Postscriptum (1969)”, w: KuHN, Struktura rewolucji..., s. 301-360.

Kunn Thomas S., Struktura rewolucji naukowych, przeł. Helena Ostromęcka i Justyna Nowotniak, Aletheia, Warszawa 2001.

Kunn Thomas S., „The Function of Dogma in Scientific Research”, w: Crombie (ed.), Scientific Change..., s. 347-369.

Lakatos Imre, „Criticism and the Methodology of Scientific Research Programmes”, Proceedings of the Aristotelian Society. New Series 1968-1969, vol. 69, s. 149-186.

LAKATOS Imre, „Falsyfikacja a metodologia naukowych programów badawczych”, w: LAKATOS, Pisma z filozofii..., s. 3-169. 
LaKatos Imre, Pisma z filozofii nauk empirycznych, przeł. Wojciech Sady, Biblioteka Wspótczesnych Filozofów, Wydawnictwo Naukowe PWN, Warszawa 1995.

Lakatos Imre and Feyerabend Paul, For and Against Method: Including Lakatos's Lectures on Scientific Method and the Lakatos-Feyerabend Correspondence, ed. Matteo Motterlini, The University of Chicago Press, Chicago and London 1999.

Lakatos Imre and Musgrave Alan (eds.), Criticism and the Growth of Knowledge, Cambridge University Press, Cambridge 1970.

LARSON Ronald G., „O argumencie z Boga w lukach wiedzy raz jeszcze”, przel. Joanna Popek, Filozoficzne Aspekty Genezy 2012, t. 9, s. 199-220, https://tiny.pl/xhzg7 (24.11.2018).

LeKKA-KowalıK Agnieszka, „Nauka wolna od wartości — groźna utopia współczesnej kultury", https://tiny.pl/thmb7 (23.11.2018).

LemańsKa Anna, „Ewolucja jako realizacja projektu?”, Filozofia i Nauka 2015, t. 3, s. 353358, https://tiny.pl/tqw4j (24.12.2018).

LenIN Włodzimierz Iljicz, „Dziecięca choroba «lewicowości» w komunizmie”, w: LenIN, Dziela. Tom 31..., s. 5-106.

LenIN Włodzimierz Iljicz, Dzieła. Tom 14. 1908 (Materializm a empiriokrytycyzm), przekład (anonimowy) z czwartego wydania rosyjskiego przygotowanego przez Instytut Marksa-Engelsa-Lenina przy KC WKP(b), Książka i Wiedza, Warszawa 1955.

LenIN Włodzimierz Iljicz, Dzieła. Tom 31, przekład (anonimowy) z czwartego wydania rosyjskiego przygotowanego przez Instytut Marksa-Engelsa-Lenina przy KC WKP(b), Książka i Wiedza, Warszawa 1955.

Le Roy Edouard, „Nauka i filozofia”, przeł. Marcelina Zuber, w: SzlachCic, Filozofia nauki..., s. 99-124.

Leszczyński Damian (red.), Ewolucja. Filozofia. Religia, Lectiones \& Acroases Philosophicae 2010, vol. 3 .

LUKIERSKI Jerzy, „Nauka i religia — czy można pogodzić”, s. 1-5, https://tiny.pl/gzpd2 (24. 11.2018)

ŁUKASIEwICZ Jan, „Dwaj filozofowie nowożytni: Kartezjusz i Kant”, Filozofia Nauki 1997, t. 5 , $\mathrm{nr} 2$, s. 159-166.

Machamer Peter and Silberstein Michael (eds.), The Blackwell Guide to the Philosophy of Science, Blackwell Publishers Ltd., Malden - Oxford 2002.

MaLec Grzegorz, „Teologiczne dylematy Karola Darwina”, Roczniki Filozoficzne 2012, t. 60, nr 1, s. 67-85, http://tiny.pl/g4751 (23.11.2018).

McDonald Patrick and Tro Nivaldo J., „In Defense of Methodological Naturalism”, Christian Scholar's Review 2009, vol. 38, no. 2, s. 201-229, https://tiny.pl/thtq7 (24.11.2018). 
McMulLin Ernan, „Odmiany naturalizmu metodologicznego”, przeł. Ewelina Topolska, Filozoficzne Aspekty Genezy 2012, t. 9, s. 109-129, https://tiny.pl/xh8pf (23.11.2018).

Metallmann Joachim, „Nauka, pogląd na świat, filozofia”, odbitka z Przeglądu Wspótczesnego 1939, nr 5-7, s. 1-49, https://tiny.pl/gzn7n (23.11.2018).

MeYer Stephen C., „DNA a pochodzenie życia. Informacja, specyfikacja i wyjaśnienie”, przeł. Dariusz Sagan, Filozoficzne Aspekty Genezy 2005/2006, t. 2/3, s. 133-215, https://ti ny.pl/q3mlb (23.11.2018).

MeYer Stephen C., Signature in the Cell: DNA and the Evidence for Intelligent Design, Harper One, New York 2009.

Meyer Stephen C., „The Use and Abuse of Philosophy of Science: A Response to Moreland", Perspectives on Science and Christian Faith 1994, vol. 46, no. 1, s. 19-21, https://ti ny.pl/h2wcm (23.11.2018).

Michalczenia Jakub, Mizíśska Jadwiga i Ossowska Katarzyna (red.), Poszukiwania filozoficzne. T. 1. Nauka. Prawda. Panu Profesorowi Józefowi Dębowskiemu w darze, Instytut Filozofii Uniwersytetu Warmińsko-Mazurskiego w Olsztynie, Olsztyn 2014.

Miller Keith B., „The Misguided Attack on Methodological Naturalism”, w: SchNeIDERMAN and Allmon (eds.), For the Rock Record..., s. 117-140.

MoKRZYCKI Edmund (red.), Racjonalność a styl myślenia, Wydawnictwo IFiS PAN, Warszawa 1992.

Moreland James Porter (ed.), The Creation Hypothesis: Scientific Evidence for an Intelligent Designer, InterVarsity Press, Downers Grove 1994.

MunÉvar Gonzalo (ed.), Beyond Reason: Essays on the Philosophy of Paul K. Feyerabend, Boston Studies in the Philosophy of Science, vol. 132, Kluwer Academic Publishers, Dordrecht — Boston — London 1991.

MunÉvAr Gonzalo, Radical Knowledge: A Philosophical Inquiry into the Nature and Limits of Science, Hacket Publishing Company, Indianapolis 1981.

Newton Isaac, Matematyczne zasady filozofii przyrody, przeł. Jarosław Wawrzycki, Copernicus Center Press, Kraków 2011.

Newton-Smith William H., „The Underdetermination of Theory by Data”, Proceedings of the Aristotelian Society 1978, Supplement, vol. 52, s. 71-91.

NIETZsChe Fryderyk, Jutrzenka. Myśli o przesądach moralnych, przeł. Leon Marian Kalinowski, Wydawnictwo Zielona Sowa, Kraków 2006.

O’Connor Robert C., „Nauka przed sądem: analiza racjonalności naturalizmu metodologicznego", przeł. Joanna Popek i Grzegorz Rogula, Filozoficzne Aspekty Genezy 2014, t. 11, s. 95-131, https://tiny.pl/xh8tq (23.11.2018). 
ORR H. Allen, „Ponownie darwinizm kontra inteligentny projekt”, przeł. Dariusz Sagan, Filozoficzne Aspekty Genezy 2004, t. 1, s. 33-48, https://tiny.pl/gzlkt (24.11.2018).

Parascandalo Renato and Hösle Vittorio, „Three Interviews with Paul K. Feyerabend”, Teleos. A Quarterly Journal of Critical Thought 1995, no. 102, s. 115-148.

Pearcey Nancy, „Ewolucjonizm po Darwinie”, przeł. Kazimierz Jodkowski, w: JodKowski, Metodologiczne aspekty..., s. 431-446.

Pennock Robert T., „Bóg w lukach wiedzy: argument z niewiedzy i ograniczenia naturalizmu metodologicznego", przeł. Dariusz Sagan, Filozoficzne Aspekty Genezy 2012, t. 9, s. 155-185, https://tiny.pl/tht9b (25.11.2018).

Pennock Robert T., „Naturalism, Evidence and Creationism: The Case of Phillip Johnson”, Biology and Philosophy 1996, vol. 11, s. 543-559, https://tiny.pl/thttp (24.11.2018).

Pennock Robert T., Tower of Babel: The Evidence Against the New Creationism, MIT Press, Cambridge 1999.

Peters Ted, „Naturalism of the Gaps”, Theology and Science 2015, vol. 13, no. 1, s. 4-7, https://tiny.pl/g36vq (23.11.2018).

PINE Ronald H., „But Some of Them Are Scientists, Aren't They?”, Creation/Evolution 1984, no. 14, s. 6-18, https://tiny.pl/g2vxk (15.01.2019).

Plantinga Alvin, „Naturalizm metodologiczny?”, przeł. Radosław Plato, Filozoficzne Aspekty Genezy 2014, t. 11, s. 37-93, https://tiny.pl/xh89b (24.11.2018).

PLATo Radosław, „Relatywizm ewolucyjny w ujęciu Gonzalo Munévara. Zarys stanowiska filozoficznego", w: Bylica, Kilian, PIotrowski i Sagan (red.), Filozofia - nauka - religia..., s. 239-260, https://tiny.pl/thtxv (24.11.2018).

PoE Harry Lee i Мүтүк Chelsea Rose, „Od metody naukowej do naturalizmu metodologicznego. Ewolucja idei”, przeł. Bartosz Błaszczak, Gerard Dmuch, Ewa Komorowska, Iwona Kumiszcze, Izabela Obłaczyńska, Katarzyna Piłka, Radosław Plato, Marika Poprawska, Dariusz Sagan, Karolina Stencel, Katarzyna Szot i Piotr Wróblewski, Filozoficzne Aspekty Genezy 2011, t. 8, s. 137-151, https://tiny.pl/xh8gd (24.11.2018).

PoINCARÉ Henri, Wartość nauki, przeł. Ludwik Silberstein, Nakład Jakóba Mortkowicza, G. Centnerszwer i Ska, Księgarnia H. Altenberga, Warszawa — Lwów 1908, https://tiny.pl /thtmq (24.11.2018).

Polanyi Michael, „The Republic of Science: Its Political and Economic Theory”, Minerva 2000, vol. 38, s. 1-32, https://tiny.pl/thtm3 (24.11.2018).

PoMORSкI Jan (red.), Wartość relatywizmu jako postawy poznawczej, Realizm. Racjonalność. Relatywizm, t. 11, Wydawnictwo UMCS, Lublin 1989. 
PoPPER Karl R., Droga do wiedzy. Domysły i refutacje, przeł. Stefan Amsterdamski, Biblioteka Współczesnych Filozofów, Wydawnictwo Naukowe PWN, Warszawa 1999.

POPPER Karl R., Logika odkrycia naukowego, przeł. Urszula Niklas, Państwowe Wydawnictwo Naukowe, Warszawa 1977.

PoPPER Karl R., Mit schematu pojęciowego. W obronie nauki i racjonalności, przeł. Bohdan Chwedeńczuk, Książka i Wiedza, Warszawa 1997.

POPPER Karl R., „Natura problemów filozoficznych i ich korzenie w nauce”, w: PoPPER, Droga do wiedzy..., s. 117-169.

Popper Karl. R., Nieustanne poszukiwania. Autobiografia intelektualna, przeł. Adam Chmielewski, Wydawnictwo Znak, Kraków 1997.

PopPer Karl R., „O źródłach wiedzy i niewiedzy”, w: Popper, Droga do wiedzy..., s. 11-57.

Popper Karl R., Quantum Theory and the Schism in Physics: From the Postscript to the Logic of Scientific Discovery, ed. W.W. Bartley III, Rowman and Littlefield, Totowa, New Jersey 1982.

PoPPer Karl R., „Racjonalność rewolucji”, w: PoPPer, Mit schematu pojęciowego..., s. 1340.

Popper Karl R., „Replies To My Critics”, w: Schilpp (ed.), The Philosophy of Karl Popper..., s. 961-1197.

Preston John, „Science as Supermarket: «Postmodern» Themes in Paul Feyerabend's Later Philosophy of Science", w: Preston, Munévar, and Lamb (eds.), The Worst Enemy..., s. $80-101$.

Preston John, Munévar Gonzalo, and Lamb David (eds.), The Worst Enemy of Science?: Essays in Memory of Paul Feyerabend, Oxford University Press, New York, Oxford 2000 .

Provine William B., „Projekt? Tak! Ale czy inteligentny?”, przeł. Sławomir Piechaczek, Filozoficzne Aspekty Genezy 2005/2006, t. 2/3, s. 217-237, https://tiny.pl/xh8rs (24.11. 2018).

Radner Michael and WinOKur Stephen (eds.), Analyses of Theories and Methods of Physics and Psychology, Minnesota Studies in the Philosophy of Science, vol. 4, University of Minnesota Press, Minneapolis 1970.

Ratzsch Del, Science \& Its Limits: The Natural Sciences in Christian Perspective, InterVarsity Press, Downers Grove, Illinois 2000.

RATzSCH Del, „Teologia naturalna, naturalizm metodologiczny i «żółwie do samego dołu»”, przeł. Dariusz Sagan, Filozoficzne Aspekty Genezy 2016, t. 13, s. 119-152, https://tiny.p1/th gbx (24.11.2018). 
RENNIE John, „15 odpowiedzi na nonsensowne tezy kreacjonistów”, przeł. Karol Sabath, Świat Nauki 2002, nr 9, s. 66-72, https://tiny.pl/g2s2c (15.01.2019).

Roskal Zenon E., „Eksperyment MacDougalla w epistemicznym układzie odniesienia naturalizmu", w: Bylica, Kilian, Piotrowski i Sagan (red.), Filozofia - nauka - religia..., s. 165-172, https://tiny.pl/g28sj (24.12.2018).

Ruse Michael, Darwinism Defended: A Guide to the Evolution Controversies, AddisonWesley, Reading, Massachusetts 1982.

RYLAND Mark, „«Teoria inteligentnego projektu» podważa teorię ewolucji. Już sama złożoność stworzenia świadczy o działaniu siły wyższej. Darwinizm? Nie ma szans. Wywiad z Michaelem J. Behe'em dla Our Sunday Visitor", przeł. Dariusz Sagan, Na Poczattu... 2004, nr 11-12A (187-188), s. 414-420, https://tiny.pl/g2vmb (25.11.2018).

SADY Wojciech, „Czego Kazimierz Jodkowski nie dostrzega, jeśli o odkrycia naukowe chodzi?", w: Bylica, Kilian, Piotrowski i Sagan (red.), Filozofia - nauka - religia..., s. 5964, https://tiny.pl/g268h (24.11.2018).

SADY Wojciech, „Dlaczego kreacjonizm «naukowy» nie jest naukowy i dlaczego nie prowadzi do teizmu?", Przeglad Filozoficzny - Nowa Seria 2001, nr 1 (37), s. 213-228, https: //tiny.pl/gdw91 (21.12.2018).

SADY Wojciech, „Kuhn kontra Fleck a Maxwellowska rewolucja w elektrodynamice”, Przegląd Filozoficzny - Nowa Seria 2010, nr 2, s. 103-131.

SADY Wojciech, Spór o racjonalność naukową. Od Poincarégo do Laudana, Monografie FNP, Wrocław 2000.

SAGAN Dariusz, Metodologiczno-filozoficzne aspekty teorii inteligentnego projektu, $\mathrm{Bi}$ blioteka Filozoficznych Aspektów Genezy, t. 6, Instytut Filozofii Uniwersytetu Zielonogórskiego, Zielona Góra 2015, https://tiny.pl/g7m72 (24.11.2018).

SAGAN Dariusz, „Naturalizm metodologiczny a zagadnienie prawdy w nauce”, w: ZACHARIASZ (red.), Poznanie a prawda..., s. 167-173, https://tiny.pl/q33sv (15.01.2019).

SAGAN Dariusz, „Naturalizm metodologiczny - konieczny warunek naukowości?”, Roczniki Filozoficzne 2013, t. 61, nr 1, s. 73-91, https://tiny.pl/q33sb (23.11.2018).

SAGAN Dariusz, „Problem religijnego charakteru teorii inteligentnego projektu”, Studia Philosophica Wratislaviensia 2011, vol. VI, fasc. 4, s. 55-74, https://tiny.pl/q336q (24.11. 2018).

SAGAN Dariusz, „Spór o możliwość wykrywania projektu w naukach przyrodniczych”, Scientia et Fides 2015, vol. 3, nr 1, s. 87-113, https://tiny.pl/gz16f (15.01.2019).

SAGAN Dariusz, Spór o nieredukowalną zlożoność ukladów biochemicznych, Biblioteka Filozoficznych Aspektów Genezy, t. 5, Wydawnictwo MEGAS, Warszawa 2008, https://tiny .pl/qzq8p (24.11.2018). 
SAGAn Dariusz, „Spór o użyteczność teorii inteligentnego projektu dla nauki”, Kultura i Edukacja 2013, nr 3 (96), s. 28-49, https://tiny.pl/xhhg3 (24.11.2018).

SAGAN Dariusz, „Teoria inteligentnego projektu a naukowa debata nad pochodzeniem”, w: JodKowsKi (red.), Teoria inteligentnego projektu..., s. 79-122, https://tiny.pl/qzq8f (16. 01.2018).

SAGAn Dariusz, „Teoria inteligentnego projektu - argumenty za i przeciw”, w: JANECZEK, Starościc, DąBeK i Herda (red.), Filozofia przyrody..., s. 335-383, https://tiny.pl/q336w (23.11.2018).

SAGAn Dariusz, „Trzy płaszczyzny argumentu z nieredukowalnej złożoności”, Na Począ$k u \ldots$ 2005, nr 5-6 (194-195), s. 162-224, https://tiny.pl/xh4f5 (16.01.2019).

SAGAN Dariusz, „Wyjaśnianie za pomocą praw przyrody jako warunek naukowości w sporze o ewolucję i inteligentny projekt", Studia Philosophiae Christianae 2013, t. 49, nr 1, s. 93-116, https://tiny.pl/q336g (15.01.2019).

Schilpp Paul A. (ed.), The Philosophy of Karl Popper, The Library of Living Philosophers, vol. 14, Open Court, La Salle, Illinois 1974.

Schneiderman Jill S. and Allmon Warren D. (eds.), For the Rock Record: Geologists on Intelligent Design, University of California Press, Berkeley — London 2009.

Scoтt Eugenie C., „Darwin Prosecuted: Review of Johnson's Darwin on Trial”, Creation/ Evolution Journal 1993, vol. 13, no. 2, s. 36-47, https://tiny.pl/g28vq (24.11.2018).

Scott Eugenie C. and Cole Henry, „The Elusive Scientific Basis of Creation «Science»”, The Quarterly Review of Biology 1985, vol. 60, s. 21-30, https://tiny.pl/tqdzw (15.01.2019).

Shanks Niall, God, the Devil, and Darwin: A Critique of Intelligent Design Theory, Oxford University Press, New York 2004.

SкоLıмоwsкi Henryk, „Evolutionary Rationality”, PSA: Proceedings of the Biennial Meeting of the Philosophy of Science Association 1974, s. 191-213.

SoBER Elliott, „Teoria inteligentnego projektu a nadnaturalizm — o tezie, że projektantem może być Bóg lub istoty pozaziemskie", przeł. Sławomir Piechaczek, Filozoficzne Aspekty Genezy 2007/2008, t. 6/7, s. 21-39, https://tiny.pl/xhn85 (25.11.2018).

Strahler Arthur N., Understanding Science: An Introduction to Concepts and Issues, Prometheus Books, Buffalo, New York 1992.

SzlachCic Krzysztof, Filozofia nauk empirycznych Pierre'a Duhema, Wydawnictwo Uniwersytetu Wrocławskiego, Wrocław 2011.

SzLACHCIC Krzysztof, Filozofia nauki francuskiego konwencjonalizmu, Wydawnictwo Uniwersytetu Wrocławskiego, Wrocław 1994. 
WaLcZAK Monika, „Stanisława Kamińskiego poglądy na cel nauki”, Zagadnienia Naukoznawstwa 2011, nr 3 (189), s. 391-405, https://tiny.pl/gztwm (23.11.2018).

Wartofsky Marx W., „How to Be a Good Realist”, w: MunÉvar (ed.), Beyond Reason..., s. $25-40$.

Watkins John W.N., „Against «Normal Science»”, w: LaKatos and Musgrave (eds.), Criticism..., s. 25-38.

Wigner Eugene P., „Niepojęta skuteczność matematyki w naukach przyrodniczych”, przeł. Jacek Dembek, Zagadnienia Filozoficzne w Nauce 1991, vol. 13, s. 5-18, https://tiny.pl/txr $8 \mathrm{z}(16.01 .2019)$.

Williams Devon, „Friday Five: William A. Dembski”, CitizenLink.com 14 December 2007, https://tiny.pl/g3h6z (24.11.2018).

WILSON Edward O., O naturze czlowieka, przeł. Barbara Szacka, Wydawnictwo Zysk i Ska, Poznań 1998.

WITT Jonathan, „Zarys historii powstania naukowej teorii inteligentnego projektu”, przeł. Dariusz Sagan, Na Początku... 2005, nr 9-10 (198-199), s. 352-362, https://tiny.pl/xhh8q (25.11.2018)

WoleńSKi Jan, „O tak zwanych filozoficznych założeniach nauki”, w: Butryn (red.), Z zagadnień filozofii..., s. 7-16.

Zachariasz Andrzej L. (red.), Poznanie a prawda, Wydawnictwo Uniwersytetu Rzeszowskiego, Rzeszów 2009.

Zachariasz Andrzej L., Poznanie teoretyczne. Jego konstytucja i status, Wydawnictwo UMCS, Lublin 1990.

ZIĘBA Włodzimierz, „Metafizyka w nauce, nauka w fillozofii. Kazimierz Jodkowski i Richard Rorty", w: Bylica, Kilian, Piotrowski i Sagan (red.), Filozofia - nauka - religia..., s. 115-126.

ZoN Józef (red.), Pogranicza nauki. Protonauka — paranauka - pseudonauka, Wydawnictwo KUL, Lublin 2009.

\section{Argumenty przeciwko naturalizmowi jako epistemicznemu układowi odniesienia}

\section{Streszczenie}

Artykuł bada ważniejsze argumenty przeciwko naturalizmowi metodologicznemu. Argumenty te mają stanowić podstawę do uzasadnienia następujących tez. Naturalizm metodologiczny: źle wpływa na rozwój wiedzy; utrudnia współzawodnictwo w nauce; jest tylko częścią określonej tradycji, która została zabsolutyzowana; jest wyłącznie prowizoryczną zasadą; jest arbitralną i szkodliwą regułą; jest podejściem irracjonalnym; jest złą filozofią; 
jest ujęciem przyjmowanym bezkrytycznie. Większość antynaturalistycznych argumentów nie jest przekonująca. Jednak kilka z nich można uznać za zasadne.

Slowa kluczowe: epistemiczne układy odniesienia, naturalizm metodologiczny, decyzje metodologiczne, anarchizm epistemologiczny, antynaturalizm.

\section{Arguments against Naturalism as an Epistemic Framework}

\section{Summary}

This paper investigates the potentially plausible arguments that may be leveled against methodological naturalism. These are used to justify the following claims with regard to the latter: that it badly affects the development of knowledge, hinders competition in science, has elevated a mere part of one specific tradition to an absolute status, is only a provisory principle, is arbitrary and harmful as a principle, is irrational as an approach, amounts to bad philosophy, and involves uncritical acceptance. Most of these antinaturalistic arguments do not turn out to be convincing, but a few can be considered well-founded.

Keywords: epistemic frameworks, methodological naturalism, methodological decisions, epistemological anarchism, antinaturalism. 